Portland State University

PDXScholar

9-12-1997

\title{
Satellite remote sensing for measuring the urban forest of Portland, Oregon
}

\author{
A. Paul Newman \\ Portland State University
}

Follow this and additional works at: https://pdxscholar.library.pdx.edu/open_access_etds

Part of the Nature and Society Relations Commons, and the Physical and Environmental Geography Commons

Let us know how access to this document benefits you.

\section{Recommended Citation}

Newman, A. Paul, "Satellite remote sensing for measuring the urban forest of Portland, Oregon" (1997). Dissertations and Theses. Paper 5403.

https://doi.org/10.15760/etd.7276

This Thesis is brought to you for free and open access. It has been accepted for inclusion in Dissertations and Theses by an authorized administrator of PDXScholar. Please contact us if we can make this document more accessible: pdxscholar@pdx.edu. 


\section{THESIS APPROVAL}

The abstract and thesis of A. Paul Newman for the Master of Science in

Geography were presented May 19, 1997, and accepted by the thesis committee and the department.

COMMITTEE APPROVALS:

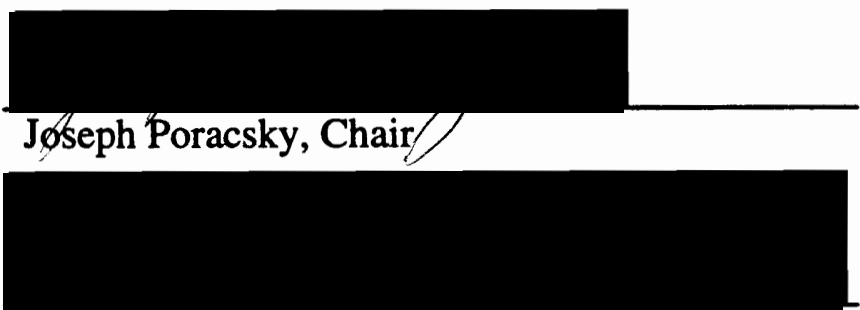

Martha Works

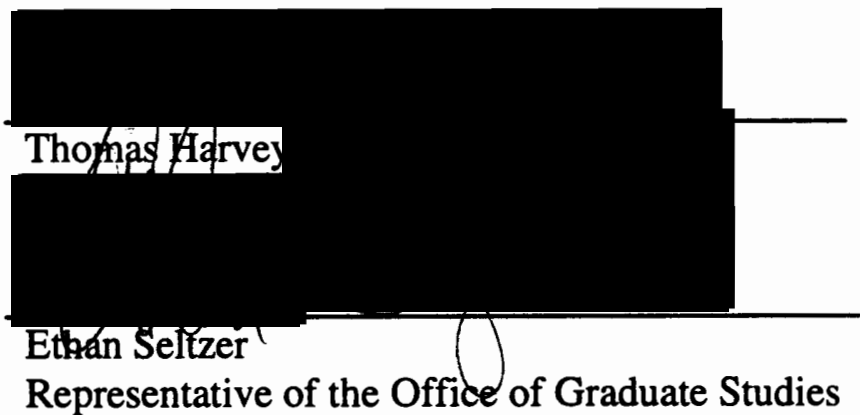

DEPARTMENT APPROVAL:

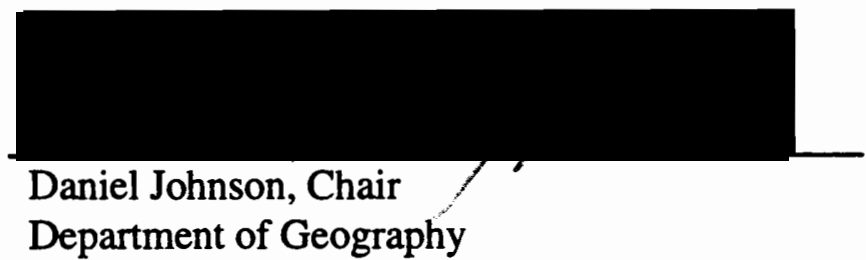

ACCEPTED FOR PORTLAND STATE UNIVERSITY BY THE LIBRARY

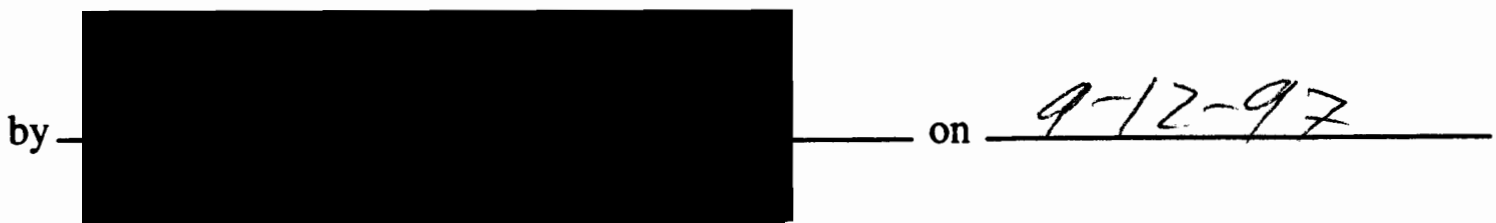




\begin{abstract}
An abstract of the thesis of A. Paul Newman for the Master of Science in Geography presented May 19, 1997.
\end{abstract}

Title: Satellite Remote Sensing for Measuring the Urban Forest of Portland, Oregon.

Digital pattern recognition methods were used to produce two maps of urban vegetation from LANDSAT Thematic Mapper for the City of Portland, Oregon. The image was acquired on July 7, 1991 and the spectral bands used were $2,4,5$ and a ratio of 3 and 4 . The two maps represent vegetation amount and vegetation type.

Due to the extreme heterogeneous nature of the urban environment, these maps were developed using techniques to reduce and manage the amount of spectral variation. This included purging non-vegetated cells from the multispectral image, and then stratifying the image into "spectral subdivisions" using tools for unsupervised classification. Each image subdivision was then classified using the standard unsupervised technique and the subdivisions reassembled. 
The two resulting maps were then statistically assessed for classification accuracy. The map representing the amount of vegetation cover was found to have an overall accuracy of $80 \%$ and the map representing the type of vegetation was found to have an overall accuracy of $73 \%$. Although previous studies have used similar imagery and techniques to map urban vegetation, none have reported accuracy figures, so direct comparison was not possible. However, these levels of accuracy are well within the range of accuracy reported by traditional remote sensing studies.

Uses of these maps include urban forest macro assessment, inventory, evaluation of ecosystem health and public education. Limitations of these maps are mostly a function to their spatial resolution. Stem counts, species detail and clearer identification of small amounts of vegetation are not directly obtainable. 


\title{
SATELLITE REMOTE SENSING FOR MEASURING THE URBAN FOREST OF PORTLAND, OREGON
}

\author{
by \\ A. PAUL NEWMAN \\ A thesis submitted in partial fulfillment of the \\ requirements for the degree of
}

MASTER OF SCIENCE

in

GEOGRAPHY

Portland State University

1997 
TO MY WIFE, JENDY

AND TO MY PARENTS, MARY AND PORTER 


\section{ACKNOWLEDGEMENTS}

I am very grateful to Dr. Joe Poracsky of the Department of Geography at Portland State University for his guidance, patience and encouragement throughout this project. Without these qualities, this project may not have come to completion.

I would also like to thank Paul Ries for hiring me as an Urban Forest Technician in Cincinnati, Ohio in 1989. It was this introduction to urban forestry that sparked my imagination towards urban forest research. Paul is currently the Urban Forest Coordinator with the Oregon Department of Forestry in Salem. His closer proximity to my work in Portland provided needed encouragement during this project.

I am also indebted to local agencies and companies for use of data and computer equipment. These include METRO, Pacific Meridian Resources, USDA Forest Service Regional Office, Portland and The Campbell Group.

Finally, to the faculty, staff and students of the Department of Geography, I extend my thanks for the education and support you have given me. Especially, Dr. Martha Works, Dr. Thomas Harvey and Dr. Ethan Seltzer who served on my 
committee. Also, to Carolyn Perry who always provided excellent advice and guidance through the graduate school experience. 


\section{TABLE OF CONTENTS}

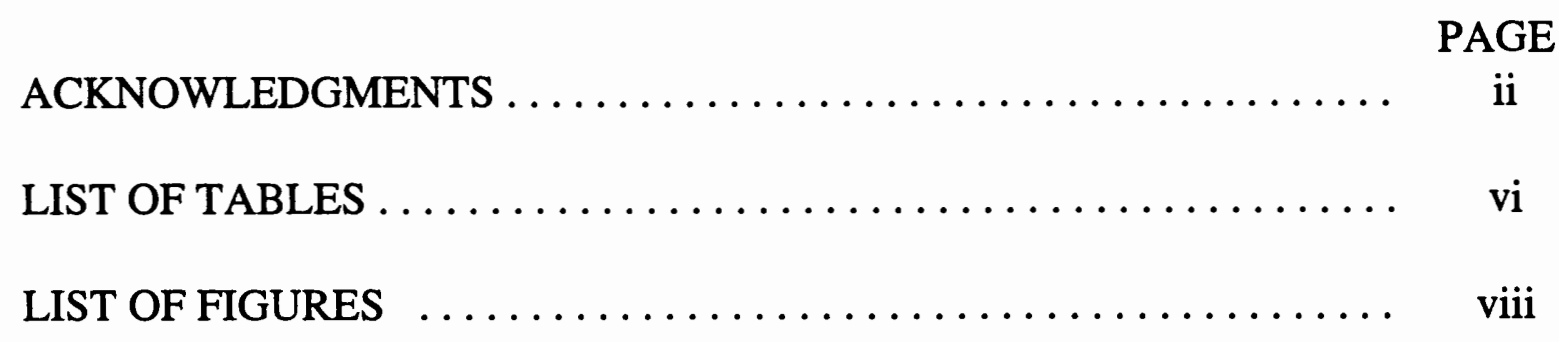

CHAPTER

I INTRODUCTION $\ldots \ldots \ldots \ldots \ldots \ldots \ldots \ldots \ldots \ldots \ldots \ldots \ldots$

The Urban Forest Defined $\ldots \ldots \ldots \ldots \ldots \ldots \ldots, 2$

Urban Forest Benefits Documented. . . . . . . . . 4

Management of the Urban Forest. ............ 6

Measuring the Urban Forest. .............. 8

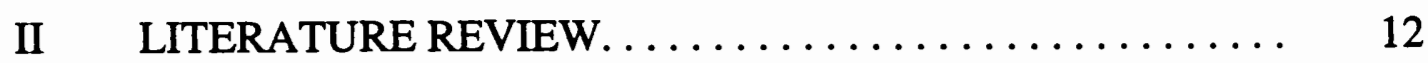

Remotely Sensed Measurements of the Urban Areas ... 12

Research Briefs on Mapping Urban Vegetation ...... 15

Discussion and Conclusions $\ldots \ldots \ldots \ldots \ldots \ldots .20$ 
III RESEARCH AND METHODS $\ldots \ldots \ldots \ldots \ldots \ldots \ldots \ldots . \ldots \ldots$

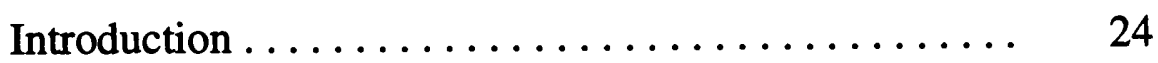

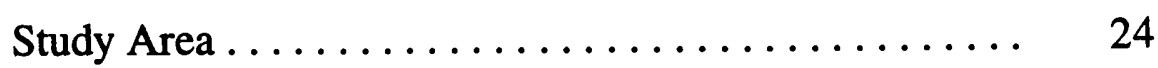

The Satellite Image $\ldots \ldots \ldots \ldots \ldots \ldots \ldots \ldots . \quad 28$

The Classification Process. ............. 32

Summary Statistics and Maps $\ldots \ldots \ldots \ldots \ldots \ldots \ldots \quad 55$

IV ACCURACY ASSESSMENT $\ldots \ldots \ldots \ldots \ldots \ldots \ldots \ldots, 61$

Assessing Two Maps $\ldots \ldots \ldots \ldots \ldots \ldots \ldots \ldots \ldots \quad 61$

Sampling $\ldots \ldots \ldots \ldots \ldots \ldots \ldots \ldots \ldots \ldots \ldots \ldots$

Error Matrices .................. 72

Discussion of Error $\ldots \ldots \ldots \ldots \ldots \ldots \ldots \ldots \ldots, 81$

Accuracy Summary and Conclusions.......... 86

V SUMMARY AND CONCLUSIONS............. 89

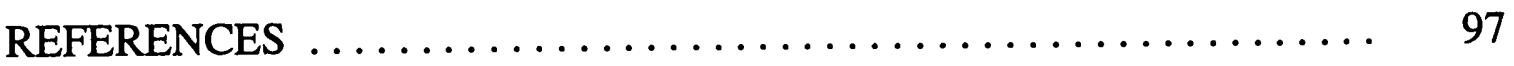

\section{APPENDICIES}

A Maps of Each of the Ten "General" Spectral Classes ........ 104

B Summary Statistics for Urban Vegetation in the City of Portland, Oregon . 


\section{LIST OF TABLES}

TABLE

PAGE

I Summary of Digital Remote Sensing Studies of Urban Forest

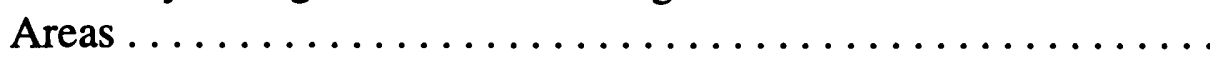

II Example Listing of Three Spectral Clusters and Their Associated Land Cover Types ...............................

III Example Listing of Spectral Samples and Corresponding Land Cover Types Associated During the Sampling Process

IV Listing of General Vegetation Classes ................

V Vegetation Based Land Cover Classes .............. 50

VI Full Listing of Vegetation Based Land Cover Classes with Acreage Reflecting Class Coverage for the Image Area Covering the City of Portland, Oregon...

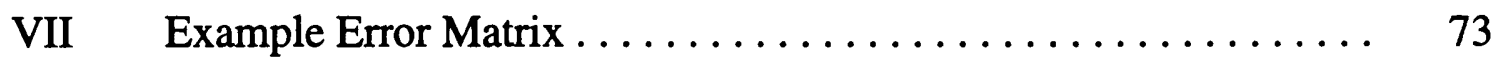

VIII Error Matrix Reporting the Accuracy Statistics for the Map

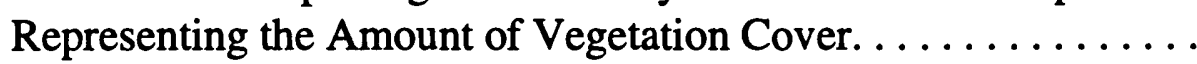

IX Proportion of Map Area Covered by Each Map Class within the

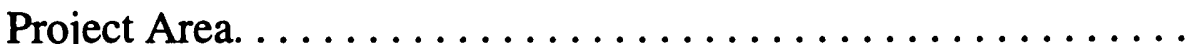

X Error Matrix Reporting the Accuracy Statistics for the Map Representing the Type of Vegetation... 
XI Proportion of Map Area Covered by Each Map Class within the

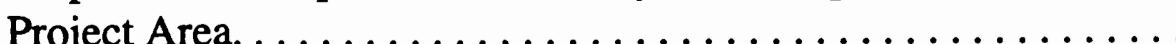

XII Summary of Reported Accuracies of Maps Produced from Satellite Imagery . . . . . . . . . . . . . . . 8 


\section{LIST OF FIGURES}

FIGURE

PAGE

1. The Forest Spectrum Displaying Different Forest Conditions. ... 2

2. Relationship between Accuracy and Image Resolution ........ 14

3. Portland, Oregon and the West Coast of the United States and Canada.

4. The City of Portland, Oregon, Area Rivers and the Satellite Image Boundary for the Study Area $\ldots \ldots \ldots \ldots \ldots \ldots \ldots .27$

5. LANDSAT Thematic Mapper (TM) Image of Portland, Oregon. . 29

6. LANDSAT Thematic Mapper (TM) Image of the Central Area of

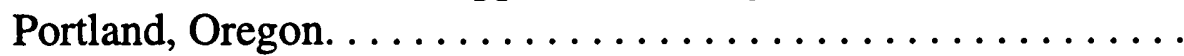

7. An Example of an Image in Raster Format Showing Recorded

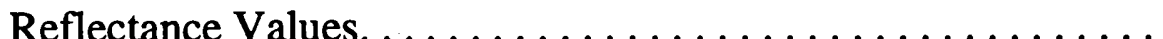

8. Three Spectral Bands, Each its Own File are Combined into a Multispectral Image, Covering the Same Area ...........

9. Majors Steps Followed to Produce an Urban Forest Map from Satellite Imagery. . . . . . . . . . . . . . . . . . . . .

10. Color Infrared Aerial Photo of the Central Business District and Surrounding Residential Areas in Portland, Oregon......... 35

11. A Comparison of Supervised and Unsupervised Classification

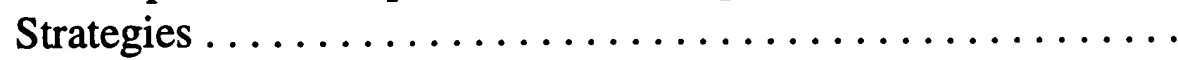


12. LANDSAT TM Image of Portland, Oregon Showing the Results of a Vegetation Ratio (bands 3/4) and "Purging" all Non-

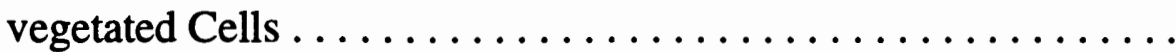

13. Raster Cells, the Land Cover Types They Cover and Cells That

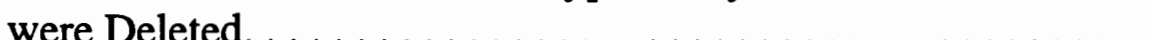

14. TM Multispectral Image with Non-vegetated Cells Masked Out. .

15. Spectral Stratification within the Multispectral Image and the Resulting Subdivisions of the Imagery. .............

16. Classsified Map of 10 "General" Classes. ............... 46

17. A Masked TM Multispectral Image Showing "Spectral Strata" or Subdivision Number "Six" Out of the Ten "General" Classes. ...

18. Color Infrared Aerial Photo and a Classified Map From One of the 10 TM Image "Subdivisions" that Cover the Same Area. . . . .

19. Classified Map with Roads Overlaid to Help Reference the Map with Aerial Photos . . . . . . . . . . . . . . . . . . . . . . .

20. Example of Fishnet Grid Used During Photo Interpretation .....

21. Example of Raster Cells Covering Mixtures of Vegetation and

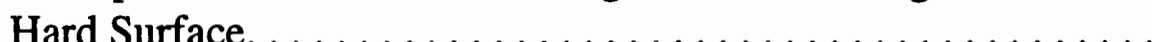

22. The Percent of Vegetation Cover in the Central Portion of Portland, Oregon. . . . . . . . . . . . . . . . . . . .

23. Vegetation Types in the Central Portion of Portland, Oregon .... 58

24. Mapped Amounts of Vegetation Coverage with Associated Acres and Percentage of Area for the Image Area Covering the City of

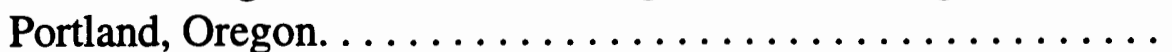


25. Mapped Vegetation Types with Associated Acreage and Percent of Area for the Image Area Covering the City of Portland, Oregon............................. 60

26. A Visual Comparison of Reference Data (CIR Aerial Photo) and the Classified Image Showing the Amount of Vegetation . . . . . .

27. A Visual Comparison of Reference Data (CIR Aerial Photo) and the Classified Image Showing the Type of Vegetation . . . . . . .

28. The Formula for Standard Error is Shown Along with its Use to Determine the Confidence Interval. . . . . . . . . . . . . . 68

29. Flowchart Summarizing Steps to Obtain Reference Data for Comparison Against the Classified Maps of Urban Vegetation. . .

30. Portland (in Gray), the Study Area Boundary (Bold Line) and

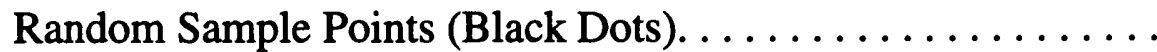

31. Vegetation as Divided by Two Image Cells and Covered by a

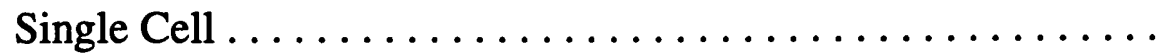




\section{CHAPTER I}

\section{INTRODUCTION}

The urban forest is increasingly being recognized for its importance to people and the environment. Because of this, comprehensive management is seen as needed to ensure the benefits urban forests provide. A fundamental concept of this management is being able to visualize the complexities of the urban forest (Grey, 1996). To help meet this need, a method is presented in this thesis to use LANDSAT Thematic Mapper satellite imagery to map the amount (percent coverage) and general vegetation types (grass, deciduous, conifer) of the urban forest.

As part of this work, earlier studies of urban forest mapping were reviewed and summarized. Methodology, which was partially based on these earlier studies, was then developed around techniques to reduce and manage the satellite image's spectral variation that was due to the extreme heterogeneous nature of urban land cover. Digital image classification then resulted in two maps of urban vegetation. As a final step, statistical accuracy assessment was conducted on the maps to measure how well the methods produced a correct representation of the urban forest. 


\section{THE URBAN FOREST DEFINED}

The concept of a spectrum can be used to describe the range of conditions under which forests exist. The position of a forest on this spectrum largely depends on the amount of human interaction on the forest's environment. At one end (Figure 1), where there is minimal human influence, forests tend to be "self managing." This condition can be described as the forest maturing through

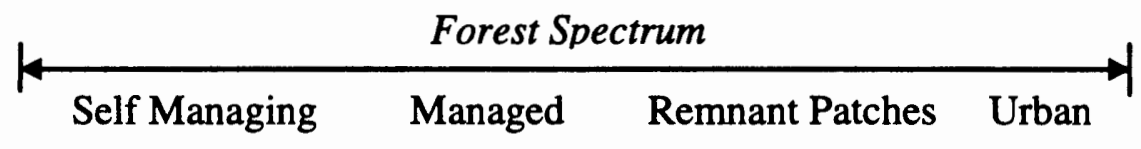

Figure 1. The forest spectrum displaying different forest conditions.

successional stages toward a climax state. (Early stages of succession often follow events of natural disturbance such as fire, wind, etc.). The full capacities for diversity and biomass generation in this environment are limited by the amount of sunlight, water, nutrients and temperature, as well as competitive advantages / disadvantages of individual species.

Moving from left to right along this simple spectrum, limitations to growth and diversity tend to increase due to the influence of people (holding all other variables constant). For example, the next condition on this spectrum is "managed forests." Here, forests are managed for wood products and are kept from reaching upper levels of succession. Biomass generation and diversity are therefore limited. 
Next on this spectrum might be "remnant forest patches" found near farm lands or even near the urban environment. Here, isolation and defined boundaries (e.g., plowed fields or roads) further limit growth and diversity.

Finally, on this spectrum are "urban forests." Here, in the urban environment, the limitations are likely the greatest due to the relatively high densities of pavement, buildings and people.

Despite these limitations for trees and other vegetation, they are considered an important part of the urban environment in the United States. The mere presence of dedicated park lands and public gardens in the city demonstrates that the natural environment matters to people (Kaplan, 1984). However, the urban forest consists of more that just these designated areas. The urban forest has been defined as "the sum of all woody and associated vegetation in and around dense human settlements, ranging from small communities in rural settings to metropolitan regions" (Miller, 1997).

According to Moll (1989), the urban forest begins at the suburban fringe where rural forest land (e.g., self managed, managed or non-urban forest patches) is beginning to be valued more for housing and business sites than for lumber, firewood and wilderness values. From there, the urban forest can be traced to the city center with growing space shrinking and becoming increasing dependent on riparian zones, parks, yards, boulevards and sidewalk cutouts. 
Generally, U.S. urban areas have greatly expanded over time and in doing so, have converted rural forests to urban forests. With this growth and conversion has also come an increasing awareness of urban forest values and research interest.

\section{URBAN FOREST BENEFITS DOCUMENTED}

Many tangible and intangible benefits are derived from the urban forest.

Often, when these are listed, the tangible benefits are placed first. While important, the intangible benefits such as the aesthetics of vegetation and "the experience that trees offer" should not be undersold! People have strong ties to trees that cannot (yet) be scientifically explained by tangible measures. The sights, sounds and smells of trees provide real benefits. For example, they offer contrast and relief from densely built-up city environments (Dwyer, et al., 1994).

An important part of the human experience of trees are the opportunities they provide for viewing wildlife in an urban environment. Remnant patches of forest provide habitat in the form of food and cover to a wide range of urban wildlife such as birds, squirrels, rabbits, and frogs. These areas offer opportunities for education and viewing of wildlife. Street tree and backyard components of the urban forest also contribute to these opportunities as they broaden habitat opportunities for very mobile species such as birds and squirrels. 
Dead trees in the urban forest can offer prime habitat for birds and small mammals. However, removal of dead trees often forms part of the basic justification for urban forestry programs. Clearly there is a need to remove hazardous trees, but the urban forester who is concerned about habitat will look for opportunities to let dead trees stand (Tylka, 1989).

In addition to the intangible benefits, there are many tangible and quantifiable benefits that the urban forest provides. For example, tree roots provide double benefits by both improving the water filtration through soil and by holding soil in place during storms. These benefits decrease storm runoff, sewer loads and soil erosion (Schoeneman and Doyle, 1992).

Vegetation in the urban environment filters air and absorbs various air pollutants including dirt and dust, carbon monoxide, nitrogen oxides, sulfur dioxide and carbon dioxide (McPherson, 1992; McPherson, et al., 1994). Rowntree (1989) makes a special point concerning urban trees in the context of global warming. Even though the urban forests of the world are only a small portion of the land surface, they do make a contribution to the storage of the greenhouse gas carbon dioxide. For example, a project in Canada involved the "community tree planting" of 8.5 million trees in NW Canada over four years. The planted trees will have the potential for sequestering " 4000 tonnes" of carbon per year (David, 1996). 
The urban forest lowers energy consumption for home cooling and heating. A study in Chicago, Illinois found that sheltering a house from the sun in summer reduced energy used for air conditioning by $7 \%$ per tree. Also, thermal cover and wind protection from nearby trees (especially conifers) during the winter reduced heating needs by $1.3 \%$ per tree (McPherson, et al., 1994; see also Rowntree, 1989).

Finally, Anderson and Cordell (1988) demonstrate, both from their own research and summaries of other research projects, that the presence of trees on residential property in the eastern United States is strongly associated with a 3.5\% $-4.5 \%$ increase in sales price. Kielbaso (1989) goes even further stating that the presence of trees increases the average value of a house by 5\%-10\%.

\section{MANAGEMENT OF THE URBAN FOREST}

Urban forest management has been defined as doing "that which must be done to make trees compatible and functional in the urban environment" (Grey, 1996). Ideally, this would involve the components of:

- Central coordination

- Knowledge of the total urban forest environment

- Knowledge of urban forest needs

- Plans to meet the needs

- A budget

- Effective implementation 
At some level, city government has historically filled the role of urban forest manager, at least with street trees and trees on park lands. Depending on the city, care of the urban forest may range from simply removing hazard trees to a funded program employing tree care professionals that lead regularly scheduled planting and maintenance efforts. As an example of this range, Oregon's 240 communities were surveyed to learn about their tree care programs. Results showed that only $25 \%$ of respondents had an institutionalized tree planting and care program, and only $29 \%$ of respondents said they employed a person with professional training (Reichenbach, 1992).

To help city programs, there has been a growth of state programs, federal funding and coordination programs. The 1990 federal Farm Bill provided for the America the Beautiful program, which directs financial support to states, who in turn distribute grants to local communities and groups for urban tree education, maintenance and planting.

Citizen groups are also forming and growing local "grass root" urban tree organizations. Programs such as TreePeople (Lipkis and Lipkis, 1990) in Los Angeles, California and Friends of Trees in Portland, Oregon have developed national reputations. Their goals are to educate communities about the importance of trees, as well as organize volunteer neighborhood tree planting and maintenance. Larger nonprofit organizations such as The American Forestry 
Association and The National Arbor Day Foundation (Tree City USA program) serve to raise the visibility of urban forest issues at a national level. The urban forest benefits noted earlier provides support for the contention that the money and time invested by these organizations in the urban forest is one of the few public expenditures whose value appreciates rather than depreciates over time.

\section{MEASURING THE URBAN FOREST}

It is clear that the existing urban forest has been and is paying dividends to the urban environment. Also, there is growing recognition for the need of urban forest management to ensure the continuation and growth of these benefits. A fundamental urban forest management concept is to visualize the complexities of location, ownership and condition (Grey, 1996). In other words, having an idea of how much vegetation exists and where it is. From this concept, questions arise. How many stems line a certain street? What neighborhood has the highest, or lowest canopy coverage and what is the variation in between? What percentage of a city's area is covered by vegetation? What is the biomass of trees in a city? To begin answering these questions, managers and researchers have a variety of methods and tools, depending on what is to be measured and the geographic extent of the area of concern. 
Methods using on-ground techniques usually focus on counting trees (stems). This can be as easy as driving a street and counting the number of trees per block or with more time, recording measurable tree attributes such as diameter, height and canopy size. For larger study areas, it is often impractical to count every tree, so instead, a number of samples are taken across the area. The samples can then be statistically compiled into estimates for the entire area.

Another method for determining estimates involves inferring tree numbers and / or canopy cover from a different variable that is much easier to measure or whose measurement already exists. Rowntree (1984) examined this potential when he compared city land use and canopy cover values for four United States cities within Kuchler's (1962) Eastern Mixed Hardwood Region (see also Sanders and Rowntree, 1983). Using land use maps and aerial photos, he showed that the urban forest's canopy cover can be a predictable function of land use and can vary from two percent over industrial land to 60 percent cover over park land. However, even among cities within the same forest region (as this study was), there were differences in climate and forest type (a subunit of forest region). These and other differences such as population density and city age produced forest canopy variation within similar land use classes between the cities. To use this data for other research projects, the research question would have to be constructed to accept that variation. 
A final method of measuring the urban forest involves remote sensing with either aerial photography or satellite imagery. Aerial photos have a solid reputation for being useful for mapping features that can be recognized by a human interpreter. These features can include buildings, roads, the amount of homogenous forest cover, or even individual trees. However, photo interpretation can be labor intensive. If more than one photo is used, edgematching is required between photos and results can vary due to differences in human perception of the features on the photo. There are also positional accuracy issues with photos, due to distortion caused by camera lens and terrain elevation variations.

Satellite imagery has an established place in mapping large rural areas. Its overall advantages include the ability to map large areas in a consistent, relatively accurate and efficient manner and then bring the digital data into a Geographic Information System (GIS) for further display, reclassification and analysis. Also, its positional accuracy can be established by georeferencing and terrain correction within the GIS environment.

These same advantages could also apply to mapping urban areas, but the usefulness of satellite systems for mapping urban areas has shown only mixed results. Problems primarily stem from the fact that the spatial resolution of the satellite systems can be considered coarse (20 - 30 meters), so small objects or land cover types blend in with surrounding features. 
One component of satellite-based urban mapping studies has been urban forest / vegetation mapping. The amount of vegetation detail able to be mapped (distinguished) is still uncertain, partly due to the fact that an assessment of classification accuracy has not been found in the literature. However, if these aspects of mapping urban vegetation could be documented as being reasonable, overall benefits would include being able to identify and map certain levels of vegetation for an entire city such as finding the least and most vegetated neighborhoods. With the consistency that satellite imagery offers, monitoring of the urban forest over time is possible. Also, major cities could be compared and contrasted in terms of urban vegetation (Sanders and Rowntree, 1983), even where climate and population density differ.

The next chapter will review mapping efforts of the urban forest using satellite remote sensing, as a prelude to describing the methodology which forms the core of this thesis. 


\section{CHAPTER II}

\section{LITERATURE REVIEW}

\section{REMOTELY SENSED MEASUREMENTS OF URBAN AREAS}

In July 1972, NASA launched the first of a series of spaceborne scanners, the LANDSAT Multispectral Scanner (MSS). MSS has since been joined by NASA's Thematic Mapper (TM), the French SPOT, and an Indian scanning system (IRS-1C). All of these sensors have demonstrated their effectiveness in mapping forest and agricultural land which are generally homogenous for tens, hundreds or thousands of acres. However, in mapping urban lands, the coarse resolution of the satellite image and the heterogeneity of urban areas have yielded mixed results.

It was hoped that as spatial resolutions become finer (from MSS's 79 meters to TM and SPOT's $30 \& 20$ meters), mapping accuracy of satellite imagery would improve in urban areas. However, in a comparison of MSS and TM for urban mapping, Haack, et al., (1987) concluded that this was not the case. While TM data provided better accuracy for homogeneous rural areas, the extreme heterogeneity of urban areas caused the spectral variation of TM data to be higher 
within individual urban land classes (e.g., residential) than that of MSS data. Therefore, the TM results were "less useful" than that of the MSS. The same conclusion was reached by Toll (1984) when he compared simulated TM with MSS. For urban residential lands, MSS provided higher accuracies because its "larger field of view," relative to TM, tended to "average the response from the heterogeneous" areas (Haack, et al., 1987), thereby reducing spectral variation. A possible reason for the difficulty is the fact that these satellite scanning systems are designed to optimize vegetation discrimination, not necessarily different types of "hard surface." This is likely a reason why some studies reported that the land cover feature believed to contribute most to the spectral heterogeneity of residential lands was vegetation (Toll, 1984; Cook and Iverson, 1991).

These findings on spatial resolution and accuracy in the urban environment showed that as the image resolution became more fine (from 79 to 30 meters), accuracy worsened. On the other hand, Gaydos (1991) examined the effects of digital image resolution (from 1 to 128 meters) on mapping the amount of urban vegetation and found accuracy to improve as the resolution became more fine (Figure 2).

In fact, Gaydos found "two distinct scale regions" with a "break at 8 meters." Finer resolutions (less than 8 meters) produced generally accurate results, 


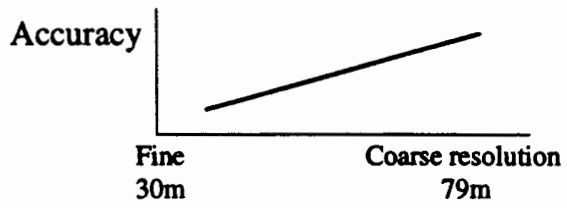

Haack, et al., (1987) and also Toll's (1984) findings

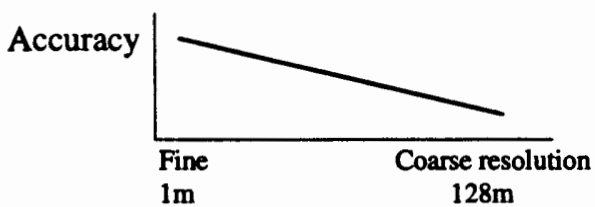

Gaydos' (1991) findings

Figure 2. Relationship between accuracy and image resolution.

but more coarse resolutions (pixels greater thar. 8 meters in size) inaccurately increased the amount of vegetation measured. How can the conflicting results of these two studies be reconciled? One explanation lies in the questions each was asking. Gaydos' study only focused on urban vegetation while the previous studies focused on a broad range of urban categories.

This provides another reason (besides image resolution) for the disappointing urban mapping results in Haack, et al. and Toll's studies. There is an important distinction between land cover and land use. Land cover consists of land surface features directly observable from above and is a function of the physical characteristics of the material. Examples include forest, grass, concrete, roof material, etc. Land use refers to the (generally) economic function that the land plays (Campbell, 1996). Examples include residential, industrial and agriculture. These are categories that cannot be "seen" by the satellite, but must be inferred from a combination of other factors. Haack, et al. and Toll were both attempting to map residential and commercial land use, even though they called it 
land cover. A focus on mapping land cover features (including vegetation) may improve the accuracy of the resulting urban area maps.

The distinction between mapping land use and land cover was also noted by Tateishi and Mukouyama in 1987. Their work used SPOT imagery to map both land use and land cover near Tokyo, Japan. The analysis showed the "poor possibility of land use classification from SPOT data," but that land cover classification, which was mostly based on varying levels of vegetation, worked well.

\section{RESEARCH BRIEFS ON MAPPING URBAN VEGETATION}

The earliest study found with a deliberate focus on mapping urban vegetation with satellite imagery was in 1987. Sadowski, Sturdevant and Rowntree examined mapping urban vegetation with MSS imagery. They found that the relatively coarse spatial resolution of MSS yielded poor results, especially in discriminating woody and herbaceous vegetation.

Four studies since have used finer resolution digital imagery to map urban vegetation and have produced promising results. The first three studies used satellite TM imagery and the fourth used a color digital orthophoto. 
The first study's objective (Wang, 1988) was to use Landsat TM to locate and analyze urban tree communities of Mobile, Alabama. In an area of 9 by 9 miles, the image analysis showed 23 spectrally distinct tree communities. Ground checking showed that these classes were distinguishable tree communities varying in species composition, age, crown closure and vertical structure. The 23 classes are a sub-group of a total of 183 classes representing all land cover types and were identified using an unsupervised strategy. The tree communities were found by comparing the raster cells of each class with reference information from photo interpretation.

Wang's 23 classes fell into one of two basic classes: 8 classes in remnant natural forests and 15 in cultivated residential trees mixed with other vegetation. The spectral response of the residential areas differed significantly from that of remnant natural forests because of the mixing of roof tops and pavement with vegetation.

The remnant natural forests usually exist where physical features such as steep slopes and wetlands preclude other urban land uses. Examples of distinct tree communities include mature pine, young mixed hardwoods and mature mixed hardwoods along with pine. Each class was associated with a crown closure percentage (e.g., 10, 20-30, 40, etc.). 
The 15 residential forest classes had two distinct groups, both of which existed mostly in neighborhoods of single-family dwellings. The first group of classes was a loose mixture of hardwoods and pine with low, but specific canopy closure values ranging from $20 \%$ to $40 \%$. Grass land cover "reflected through the tree canopy" of some classes while other classes had cars and other artificial features beneath or around the trees.

Dominant oak was the other group of classes representing residential forest communities. Mostly in affluent neighborhoods, the canopy cover of these classes ranged from $30 \%$ to $70 \%$ and were mostly mature trees. The researcher attributed the success of this study to the "high-resolution" TM data.

The second study (Cook and Iverson, 1991) focused on vegetation in Chicago. Like Wang, it used Landsat TM with an unsupervised strategy. However, the goals of this study were broader, the classes of land cover more general and the size of the study area was much larger ( 60 by 60 miles). This study's main goal was change detection using classified maps. Therefore, maps of urban vegetation cover and other land cover types (10 types in all) were made from imagery acquired at two different dates, 1985 and 1988. Examples of their land cover classes include:

- forest, crown closure $>50 \%$

- forest, crown closure $25-50 \%$

- residential $\mathrm{w} / \mathrm{veg}$ dominating 
- residential $\mathrm{w} /$ non-veg dominating

- cropland

To achieve this, an image was first stratified into two groups: "mostly urban ... and mostly rural..." using digital land use maps to make the distinction. This was done to reduce the size of the image ( 150 megabytes) into more manageable subdivisions of the image. Once the unsupervised classification was complete on each image, the urban and rural maps were merged, forming 195 spectral clusters. Aerial photos and field visits were then used to find the land cover information for each cluster, resulting in the aggregation of the clusters into the 10 land cover types.

Results of mapping were simply displayed as land cover percentage for the area (i.e., residential with vegetation dominating was $24 \%$ of the area, etc.). The change detection indicated that six percent of the region had been converted from cropland to urban uses over the three years of the study period.

The third paper (Bell, Gaydos and Rowntree, 1993) demonstrates the use of Thematic Mapper to assess urban growth and vegetation structure of a large urban region (Sacramento, California). Urban growth was measured by manually delineating urban boundaries on screen from satellite images of different dates, then comparing the two delineations. 
Vegetation structure was measured by using an unsupervised strategy where ten classes within the urban area and another ten classes outside of the urban area were constructed. Then, percentage of vegetation cover information was identified for each land cover class. The percentage of cover was found by sampling homogenous class locations on aerial photos. An example of a particular class is a residential area having tree canopy cover ranging from $5 \%$ to $16 \%$ and grass cover ranging from $20 \%$ to $36 \%$.

In their summary, Bell, et al. state that perhaps urban forest measurements could be achieved using only a single band or a linear combination such as a normalized difference vegetation index (NDVI) to calibrate the percentage of trees and grass without as much "calibration" (reference data) from aerial photos.

The fourth paper (Gaydos, 1991) had the objective of measuring the changes in urban vegetation mapping accuracy as a function of digital image resolution. While the study did not use satellite imagery, the techniques used on the digital image to map urban vegetation could be used with a satellite image.

Gaydos began with a three band digital orthophoto that included an infrared band. The cell size of the initial image was one meter, then the image was resampled multiple times to construct additional images with increasingly coarse resolutions. With each image, a vegetation ratio band was made using the infrared 
and red bands. Map classes of "vegetation," "non-vegetation" and "shadow" were established using the ratio band data and aerial photos for reference.

Results showed that the amount of vegetation mapped was consistent when the resolution ranged between 1 and 8 meters. However, as the resolution became more coarse ( $>8$ meters), the mapped amount (or area) of urban vegetation increased. One of the study's conclusions was that this finding has important implications for mapping the amount of urban vegetation with coarse imagery such as satellite imagery. The coarse resolution will likely overestimate the amount of vegetation reported.

The four studies have been summarized for comparison in Table I.

\section{DISCUSSION AND CONCLUSIONS}

Among the studies presented here, there was a significant variation in the kind of land cover categories, some mixing of land cover \& land use categories and varying degrees of the amount of vegetation cover mapped. Cook and Iverson produced general vegetation cover ranges (e.g., $25 \%-50 \%,>50)$ and grouped them along with land use categories such as residential. Bell, et al. had more specific vegetation cover percentages by class, but also mixed in land use categories with each class. Wang seems to have extracted as much urban forest 
TABLE I

\section{SUMMARY OF DIGITAL REMOTE SENSING STUDIES OF URBAN FOREST AREAS}

\begin{tabular}{|c|c|c|c|c|}
\hline Authors & $\begin{array}{l}\text { Wang } \\
\text { (1988) }\end{array}$ & $\begin{array}{l}\text { Cook and Iverson } \\
\text { (1991) }\end{array}$ & $\begin{array}{c}\text { Bell, et al. } \\
(1993)\end{array}$ & $\begin{array}{c}\text { Gaydos } \\
(1991)\end{array}$ \\
\hline City & Mobile, AL & Chicago, II & Sacramento, CA & Portland, OR \\
\hline $\begin{array}{l}\text { Study Area } \\
\text { Size }\end{array}$ & $9 \times 9$ miles & $60 \times 60$ miles ( 6 county area) & $36 \times 36$ miles & $\begin{array}{l}\text { USGS } 7.5 \text { minute } 1 / 4 \\
\text { quad }\end{array}$ \\
\hline Project Goal & $\begin{array}{l}\text { Locating and analyzing } \\
\text { urban tree communities with } \\
\text { satellite imagery }\end{array}$ & $\begin{array}{l}\text { - Urban / rural land cover } \\
\text { change study using images } \\
\text { of two dates } \\
\text { - Map urban forest cover }\end{array}$ & $\begin{array}{l}\text { - Compute urban growth } \\
\text { rates (change } \\
\text { detection) using } \\
\text { images of two dates } \\
\text { - Map and measure } \\
\text { urban forest }\end{array}$ & $\begin{array}{l}\text { - Determine scale } \\
\text { dependency of } \\
\text { vegetation in urban } \\
\text { areas } \\
\text { - Characterize urban } \\
\text { place using } \\
\text { vegetation and road } \\
\text { density data }\end{array}$ \\
\hline $\begin{array}{l}\text { Classification } \\
\text { Method }\end{array}$ & $\begin{array}{l}\text { Unsupervised and } \\
\text { Minimum Distance after } \\
\text { dividing the image into } 6 \\
\text { equal geographic areas (to } \\
\text { reduce heterogeneity). } \\
\text { Pieces were put back } \\
\text { together after classification }\end{array}$ & $\begin{array}{l}\text { Unsupervised after separating } \\
\text { "mostly urban" imagery from } \\
\text { "mostly rural" imagery. The } \\
\text { separation was done using } \\
\text { image polygon data from } \\
\text { local municipalities. }\end{array}$ & $\begin{array}{l}\text { Unsupervised and } \\
\text { Maximum Likelihood } \\
\text { after separating urban } \\
\text { image from non-urban } \\
\text { image using urban } \\
\text { boundary polygons } \\
\text { digitized on screen by } \\
\text { visually interpreting } \\
\text { image }\end{array}$ & $\begin{array}{l}\text { Construct an } \\
\text { Infrared / red band } \\
\text { ratio, then find the } \\
\text { threshold that } \\
\text { separates vegetated } \\
\text { and non-vegetated } \\
\text { cells }\end{array}$ \\
\hline Bands Used & TM $2,3,4,5$ & $\begin{array}{l}\text { TM (specific bands not } \\
\text { mentioned) }\end{array}$ & TM 2, 5, NDVI (3 \& 4) & $\begin{array}{l}3 \text { spectral band } \\
\text { digital orthophoto } \\
\text { (included infrared } \\
\text { and red) }\end{array}$ \\
\hline $\begin{array}{l}\text { Class } \\
\text { Descriptions }\end{array}$ & $\begin{array}{l}8 \text { "remnant natural forest" } \\
\text { classes - examples } \\
\text { - Mature Pine, 20\% crown } \\
\text { closure } \\
\text { - Young mixed hardwoods, } \\
\text {-50\% crown closure } \\
\text {-Etc. } \\
15 \text { "cultivated residential } \\
\text { forest" classes - examples } \\
\text { - Mature Oak, 50\% crown } \\
\text { closure } \\
\text { - Young Sycamore, 20\% } \\
\text { crown closure } \\
\text {-Etc. } \\
160 \text { non-forest classes } \\
\end{array}$ & $\begin{array}{l}\text { 10 Classes - Examples: } \\
\text {-Forest }>50 \% \text { cover } \\
\text { - Forest } 25-50 \% \text { cover } \\
\text { - Residential with trees } \\
\text { dominating } \\
\text { - Residential with impervious } \\
\text { dominating } \\
\text {-Etc. } \\
\text { (No veg mixtures) }\end{array}$ & $\begin{array}{l}10 \text { urban and } 10 \text { non- } \\
\text { urban classes } \\
\text { Examples: } \\
\text { - Wooded residential } \\
\text { - Grass residential } \\
\text { - Residential - low veg } \\
\text { - Commercial } \\
\text { - Wooded non- } \\
\text { residential } \\
\text { Classes supplemented } \\
\text { with additional photo } \\
\text { interpretation to find } \\
\text { each classes } \\
\text { composition of trees, } \\
\text { grass, etc. }\end{array}$ & $\begin{array}{l}3 \text { classes: } \\
\text { - vegetated } \\
\text { - non-vegetated } \\
\text { - shadow }\end{array}$ \\
\hline $\begin{array}{l}\text { Assessed } \\
\text { Accuracy }\end{array}$ & Not mentioned in paper & Not officially done & Not done & N/A \\
\hline Conclusions & $\begin{array}{l}\text { - Useful for promoting } \\
\text { neighborhood planning for } \\
\text { balanced forest structure } \\
\text { - Ready for GIS } \\
\text { - Useful for comparative } \\
\text { research }\end{array}$ & $\begin{array}{l}\text { - Inexpensive and accurate } \\
\text { data for land cover } \\
\text { - Change detection is error } \\
\text { prone due to problems with } \\
\text { matching two different } \\
\text { images }\end{array}$ & $\begin{array}{l}\text { - Ideal for examination } \\
\text { of whole urban forest } \\
\text { ecosystem } \\
\text { - Ideal for monitoring }\end{array}$ & $\begin{array}{l}\text {-Urban vegetation } \\
\text { mapping consistent } \\
\text { between } 1-8 \text { meter } \\
\text { resolution. Amount } \\
\text { mapped increases } \\
\text { with more coarse } \\
\text { resolution. }\end{array}$ \\
\hline
\end{tabular}


detail out of the TM imagery as possible, including specific species, and then grouped them as "native remnant" and "cultivated."

Taken as a group, these studies begin to define a methodology that is likely to provide the most useable final classification for urban forest cover. For example, all studies stratified the original imagery into subsets before using unsupervised methods to classify the image. This was done by either cutting the image into equal geographic pieces or by stratifying it with GIS polygon data from other sources. They did this to reduce variation in the spectral data during the classification work. Also, by increasing focus on the land cover classifications and minimizing land use issues, they avoided the problems of inference-induced errors associated with land use classifications (even though some of the studies still mixed in land use).

A shortcoming of these studies is that they only described their methodologies and presented the resulting classified map. None of them did a formal accuracy assessment. This obviously leaves them open to question with regard to both their absolute and relative accuracies.

In the next chapter, a study methodology is outlined for performing a vegetation based land cover classification for an urban area. The methodology seeks to incorporate the lessons learned from the studies described in this chapter, as well as to: 
1) More effectively stratify the multispectral image

2) Use a strict vegetation classification scheme

3) Statistically assess the mapping accuracy

4) Provide another test of the utility of the overall urban vegetation mapping procedure 


\section{CHAPTER III}

\section{RESEARCH AND METHODS}

\section{INTRODUCTION}

A study was conducted to examine urban forest mapping methods using image stratification and urban forest map classes that were strictly focused on vegetation-based land cover instead of land use. Following map construction, the map was statistically assessed for accuracy.

\section{STUDY AREA}

The study area is the City of Portland, Oregon (Figure 3). In 1991 (the year of the satellite image), the City of Portland covered 87,000 acres (136 square miles). The total metropolitan area is approximately 271,000 acres (423 square miles) as measured by the area's Urban Growth Boundary (in Oregon) plus the greater Vancouver, Washington area. The city's 1990 population was 435,385 (U.S. Bureau of the Census 1991a). The greater metropolitan region included 31 cities and totaled approximately $1,240,000$ people. 


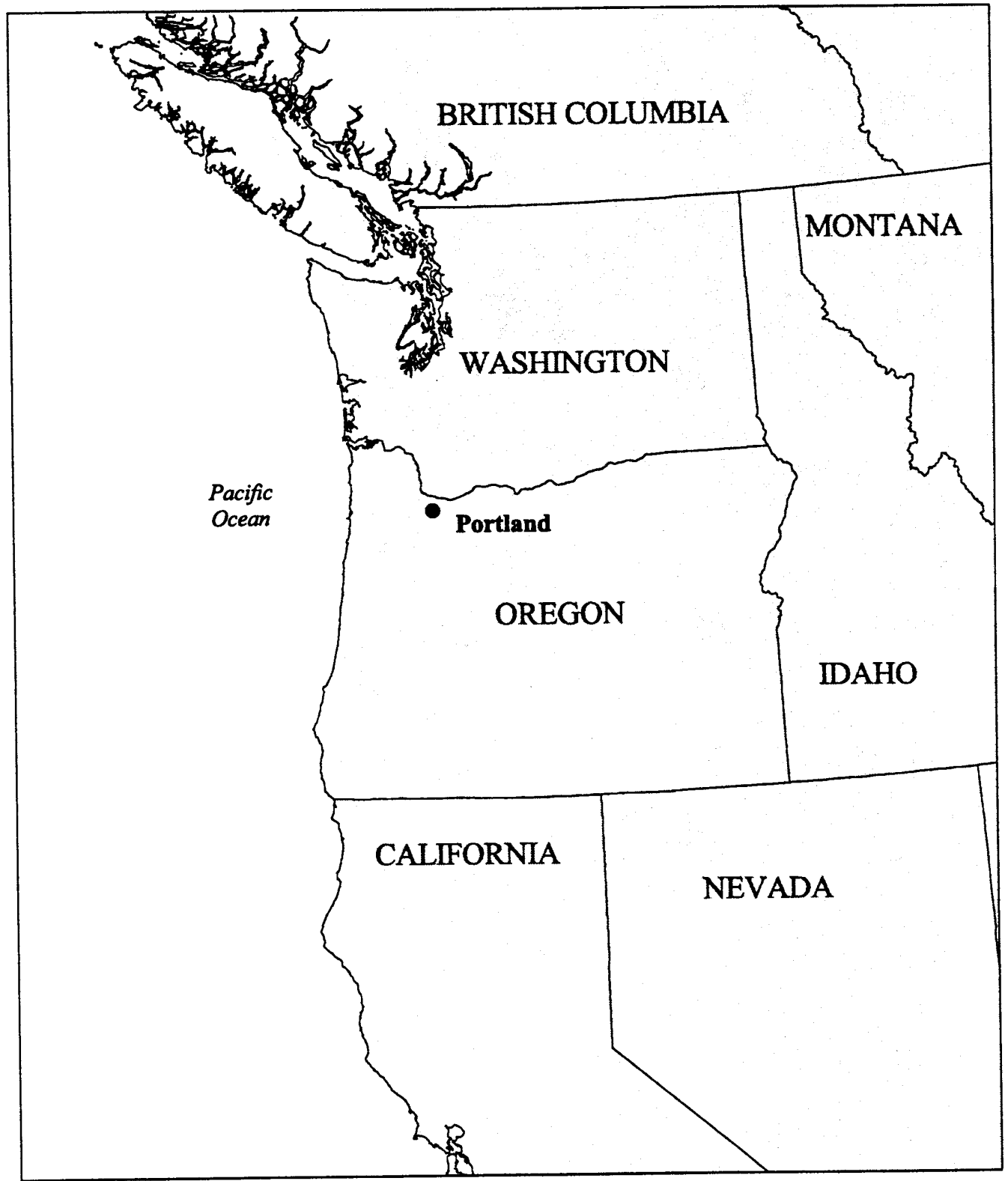

Figure 3. Portland, Oregon and the west coast of the United States and Canada. 
Figure 4 shows the City of Portland relative to the area that was mapped for this project (the image area). All summary statistics (e.g., map classes by area) in the body of this thesis will be given using the area of the image. Summary statistics for just the City of Portland will be given in Appendix B.

Portland was established in 1851 at the north end of the Willamette Valley near the confluence of the Columbia and Willamette Rivers (Figure 4). To the east lies the Cascade Mountain Range and to the west lies the Coast Range. The city's climate is characterized by wet, mild winters and warm, dry summers.

The native vegetation was strongly dominated by conifers. In the foothills, the area's historic vegetation consisted of Douglas fir (Pseudotsuga menziesii) dominated forests that also contained smaller amounts grand fir (Abies grandis),

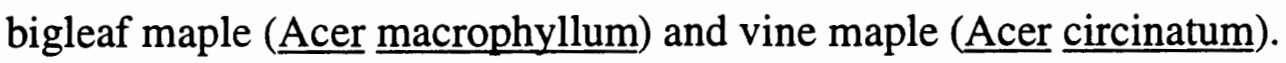
Cottonwood (Populus trichocarpa) existed (and in some areas still does) in nearly pure stands on flood plains of low gradient streams. Red alder (Alnus rubra) dominates along higher gradient streams (Franklin, 1973).

Portland is split by the north-flowing Willamette River. The east side of the city is generally flat with occasional dormant-volcanic buttes rising to 1500 feet in elevation. The west side, which contains the central business district near the river, is dominated by the Tualatin Mountains, a NW - SE trending ridge which 


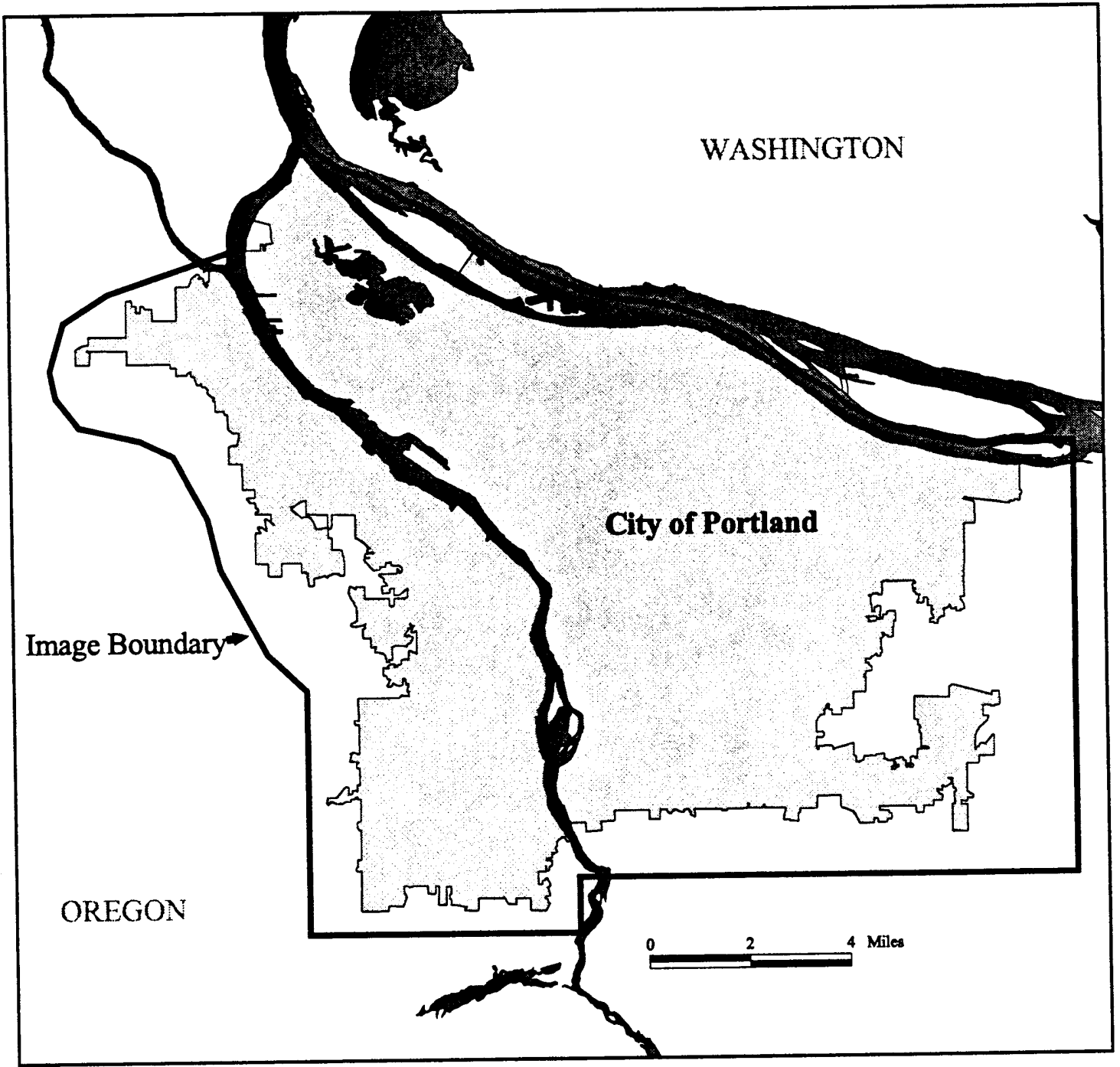

Figure 4. The City of Portland, Oregon, area rivers and the satellite image boundary for the study area. In most areas, the image boundary extends well beyond Portland's city boundary. Total image area is 128,028 acres. 
rises from a narrow flood plain at 30 feet above mean sea level (at the river) to approximately 1000 feet elevation.

\section{THE SATELLITE IMAGE}

The first goal was to produce a map from satellite imagery showing the amount and type of urban forest vegetation across the study area. This was done using a LANDSAT Thematic Mapper (TM) image dated July 7, 1991 (NASA scene ID 92141008-01) which was available for use. Figure 5 shows the full image which extends beyond the City of Portland's boundary (Figure 4). Figure 6 shows a closer view of the central portion of the image.

The satellite based sensor that captured the image has been in use since 1984 (LANDSAT V) and measures the amount of spectral reflectance of the earth's surface within a systematically sampled raster of square cells. These are also known as pixels. The spatial resolution of this sensor is 30 by 30 meters and the radiometric resolution is 8 bit (256). This means that in a raster format, each cell represents an area on the ground measuring $30 \times 30$ meters and contains a number ranging from 0 to 255 that records the reflectance for that portion of the earth's surface (Figure 7). The higher the number, the greater the reflectance or brightness. 
These preprocessing operations were done, simply as a matter of convenience for working within the UTM coordinate system.

The first step was to extract the study area data from the larger image. The image was cut from the full scene to a boundary approximately 1 mile beyond Portland's city boundary (see Figures 4 and 5). Total area of the study area image was 128,050 acres $(829,120$ raster cells $)$.

Reference information was obtained from interpretation of color infrared aerial photography. The photography varied in date from June, 1989 to July, 1991 and in scale from 1:32,000 to 1:24,000 (Figure 10). Image processing was done with ERDAS 7.5 software on a UNIX workstation.

Four of the seven available bands were chosen to make up the multispectral image. Included were TM bands 2 (visible green), 4 and 5 (infrared bands), as well as a ratio of 3 (visible red) and 4 (near infrared). These bands were found to be useful in distinguishing between trees, shrubs, and grass. The ratio band by itself, similar to a vegetation index, indicates the density of vegetation and was used to mask out non-vegetated raster cells from the initial image. During preliminary signature generation, it was found that bands 1 (visible blue), 3 (visible red), 6 (thermal) and 7 (infrared) did not add any additional data to discern vegetation types. This was found by using a tool in ERDAS, called Diverge, that 


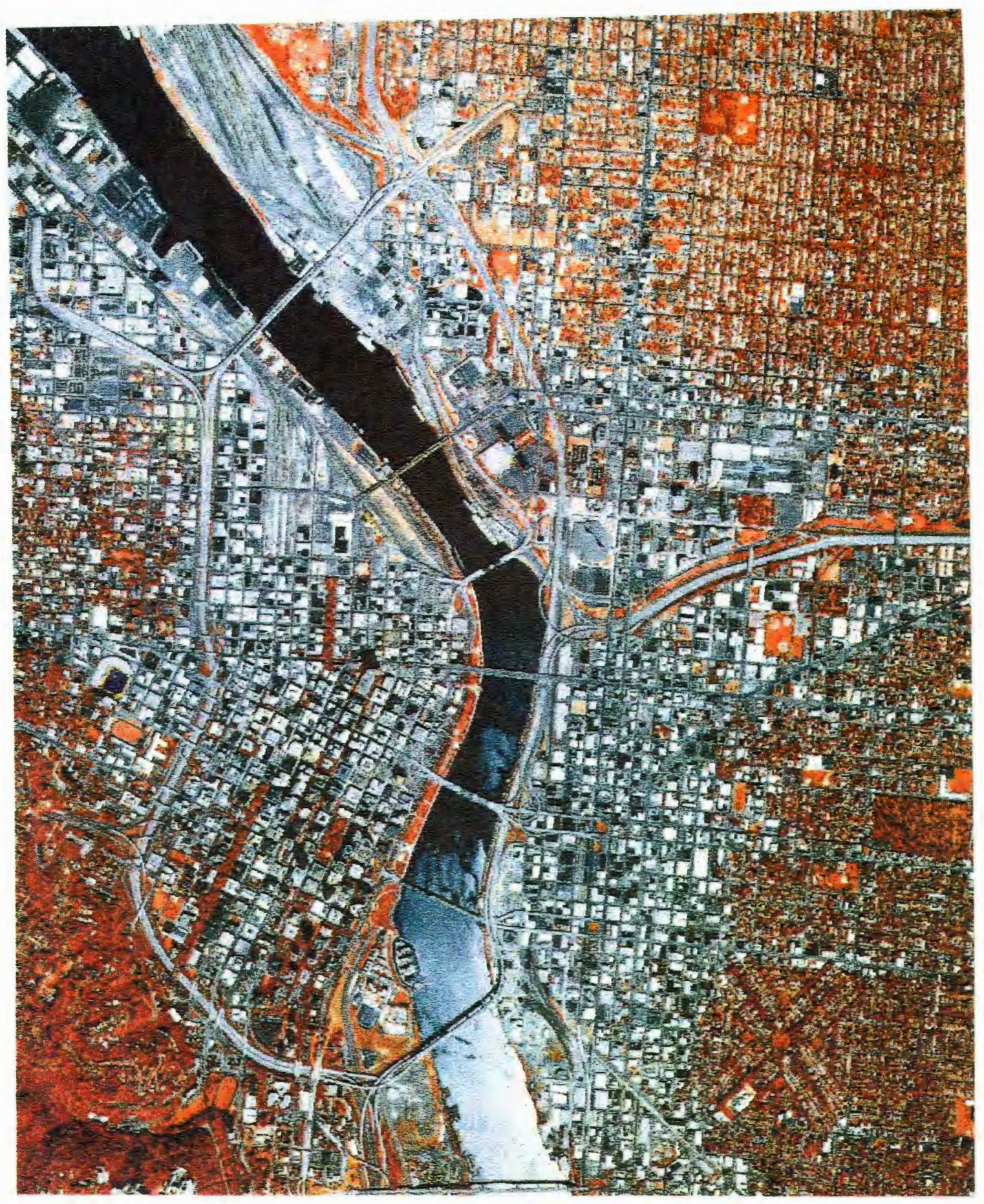

Figure 10. Color infrared aerial photo of the Centeral Business District and surrounding residential areas in Portland, Oregon. The Willamette River is flowing through the middle of the photo. Photos like this were used as reference information during image classification of the satellite image. 
examines sample clusters of key land cover types for how much each band contributes to the uniqueness of each class.

\section{Step 2: Image Processing Strategy}

Image processing is the task of using specialized computer software to make a link between land cover classes and a unique spectral signature. There are two basic strategies used to do this, unsupervised and supervised, summarized in Figure 11.

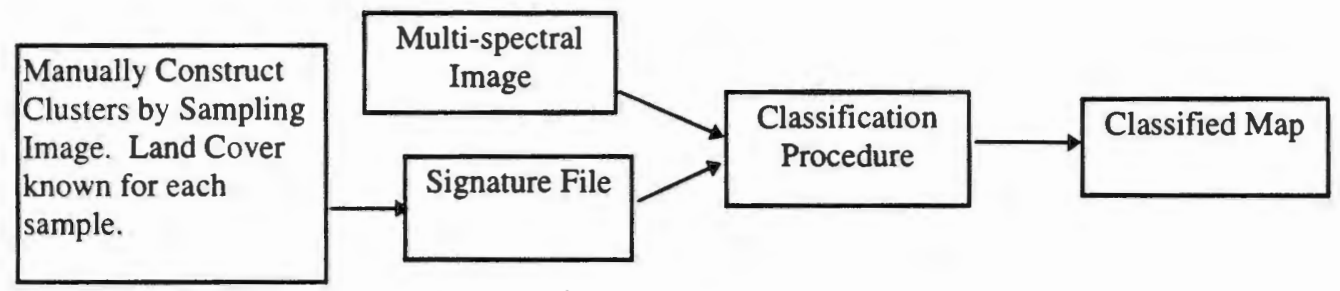

Supervised Classification strategy.

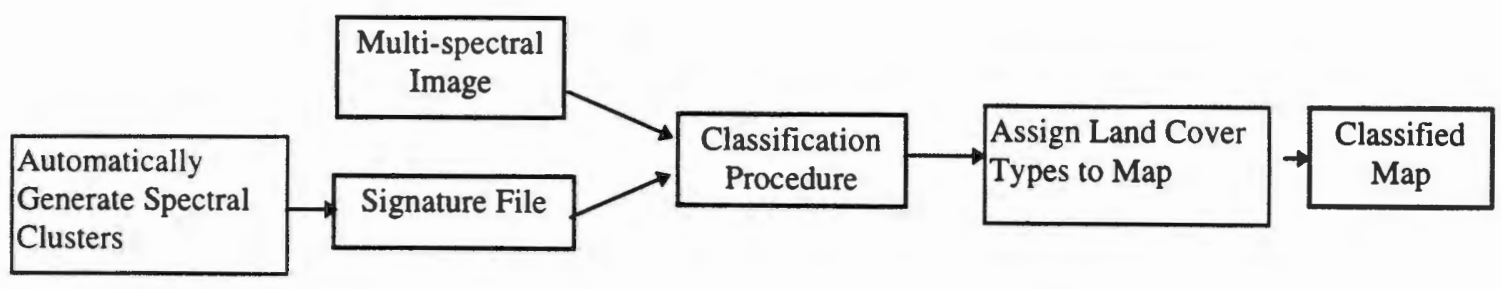

Unsupervised Classification strategy

Figure 11. A comparison of supervised and unsupervised classification strategies. 


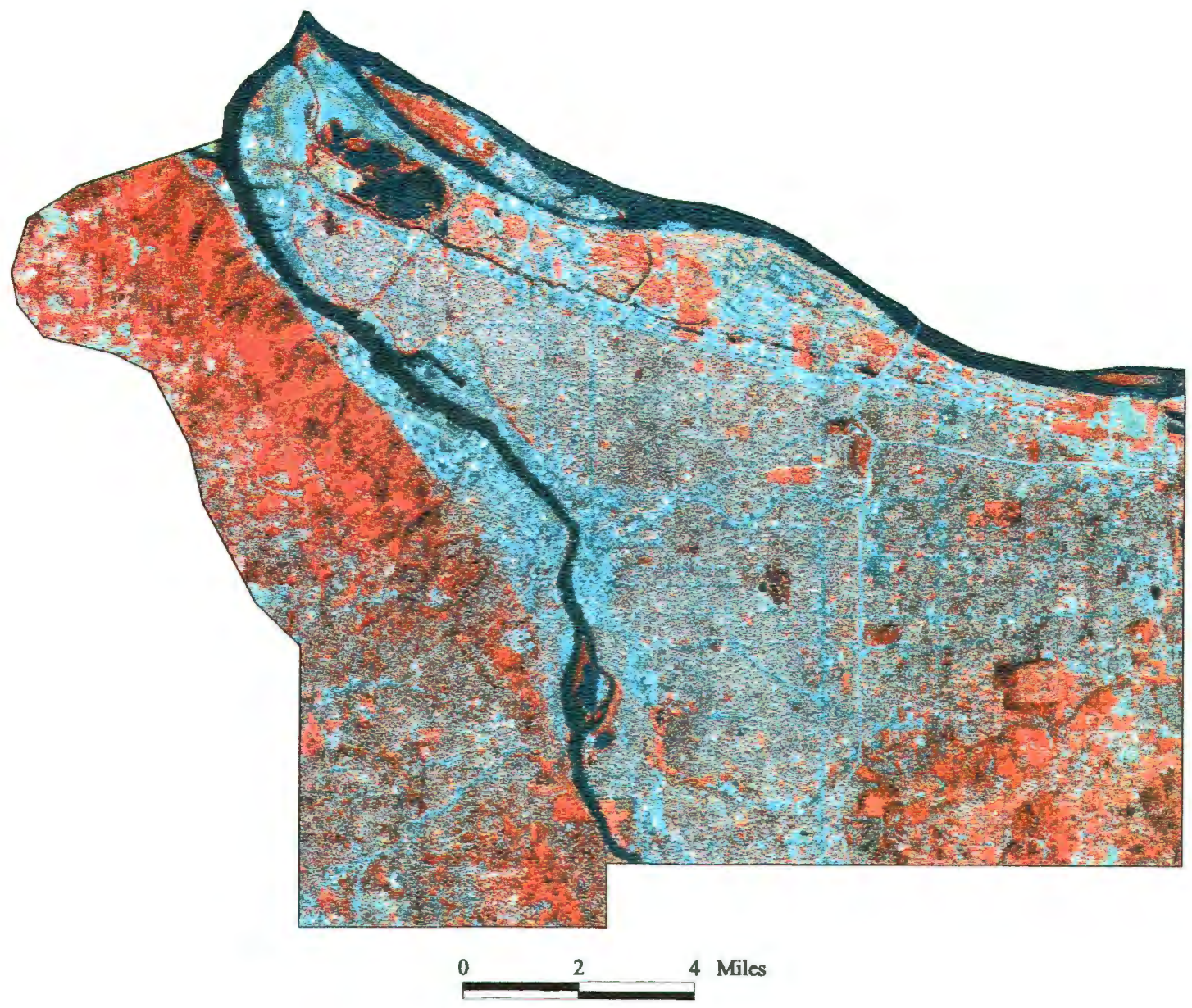

Figure 5. LANDSAT Thematic Mapper (TM) image of Portland, Oregon. The image boundary roughly follows the city boundary. TM bands 4, 3 and 2 (RGB) are displayed here. Orange-reds denote vegetation and blue-greens denote hard surface. The Willamete River is seen flowing north through the center of the image. A portion of the Columbia River is seen on the north edge of the image. 


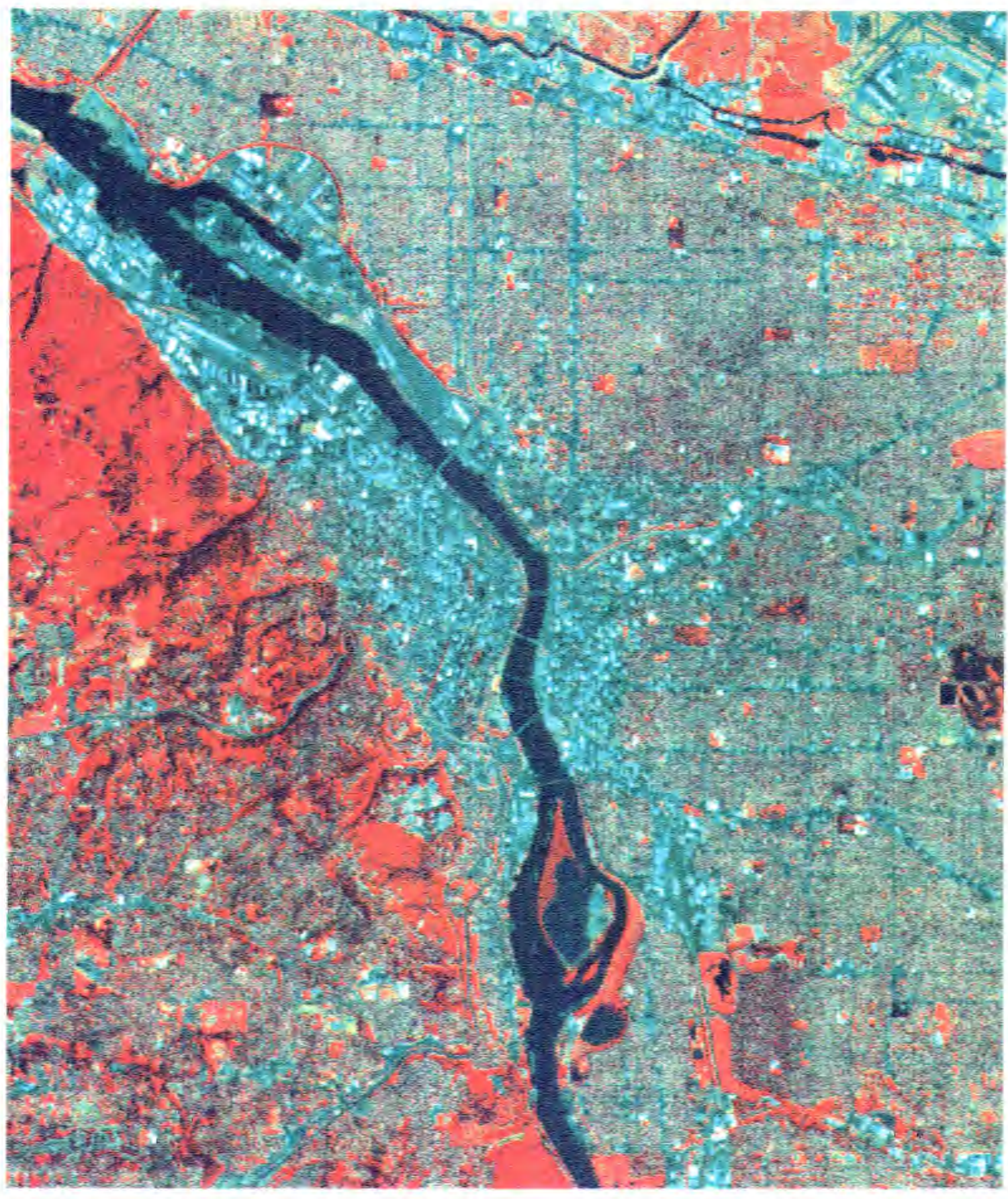

0

12

3 Miles

Eigure 6. LANDSAT Thematic Mapper (TM) image of the central area of Portland, Oregon. Orange-reds denote vegetation and blue-greens denote hard surface. The Central Business District is in the center of the image and a forested park area (deep red / orange) is in the upper left. The Willamette River flows north through the center of the image. 


\begin{tabular}{|c|c|c|c|}
\hline 67 & 78 & 89 & 156 \\
\hline 70 & 83 & 134 & 145 \\
\hline 76 & 91 & 155 & 180 \\
\hline
\end{tabular}

Figure 7. An example of an image in raster format showing recorded reflectance values.

The scanner measures the amount of energy within specific wavelength ranges. The width of the range is referred to as spectral resolution (with a narrow range indicating high resolution and a wide range indicating low resolution). Also referred to as bands, the amounts of blue, green and red are measured separately. Beyond the visible portion of this spectrum, reflected infrared energy is also measured in three additional bands and thermal infrared in another band. TM imagery thus has a total of seven bands and provides seven different data sets for a given image or scene.

In the raster format, the data can be represented in multiple raster files, one for each band. When two or more bands are used together, the data is referred to as multispectral imagery (Figure 8).

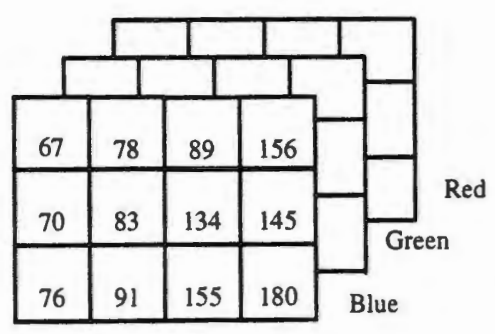

Figure 8. Three spectral bands, each its own file are combined into a multispectral image, covering the same area. 
These separate measures of energy (bands) assist in the identification of different land cover types. Because different land cover types reflect differing amounts of energy, a link can be made between a land cover type and its recorded reflectance in a combination of bands. For example, forest cover reflects infrared energy to a high degree whereas water has a relatively low reflectance of infrared. However, in the red portion of the spectrum, the reflectance for both these features is low. With knowledge of each land cover type's unique spectral response pattern (also known as spectral signature), a map of land cover types can be generated from the satellite image by matching the spectral response pattern for each image cell with the spectral response pattern for the land cover types, and identifying the image cell with the cover type that most closely matches the cell's response pattern.

\section{CLASSIFICATION PROCESS}

There are a total of six steps in the analysis (Figure 9). They will be discussed in sequence.

\section{Step 1: Image Set Up and Preprocessing and Tools Used}

When received for this project, the satellite image had already been georeferenced, terrain corrected and resampled to a cell size of 25 meters from 30 . 


\section{Step 1}

Cut image to

the study area

Step 2

Identify image

classification

strategy

Step 3

Remove image

cells not associated

with vegetation

using ratio image

Subdivide remaining

"vegetated cells" into 10

spectral subgroups using

ISODATA, Max Class and Mask

(Spectral Stratification)

Step 5

Unsupervised

Classification of each

image subgroup for

vegetative land cover

(vegetation classes and

amount of vegetation)

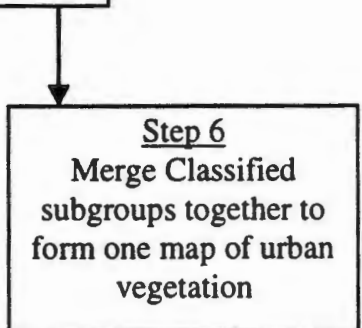

Figure 9. Major steps followed to produce urban forest map from satellite imagery. 
The unsupervised strategy looks to identify natural clusters in the numeric data, then (the user) determines what features they represent. Using an algorithm called ISODATA, groups or clusters of relatively homogenous spectral data are formed using all bands selected. The number of clusters to be formed is determined by the user. Once the spectral clusters are formed, each cell in the raster image file is classified to the "cluster class" most similar to it (using a separate algorithm called maximum likelihood classification). This produces a new digital map of the classes. In this mapped format, each class is examined to find out if it represents a specific land cover type (versus a mix of land cover types) that is desired. If it does, the land cover type is assigned to that cluster class (Table II).

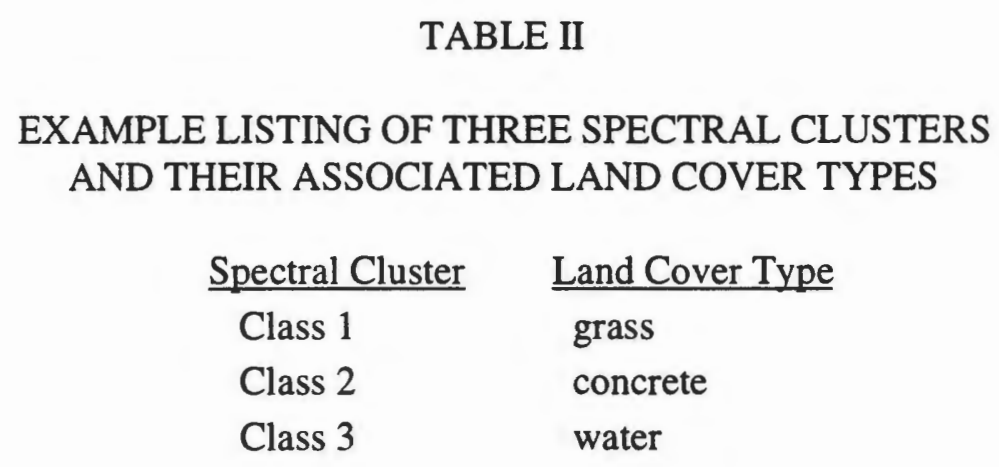

The supervised strategy begins with a pre-determined set of features, identifies their numeric (spectral) data characteristics and then assigns each cell in the image to the feature it most closely resembles. Instead of automatically generating spectral clusters and then assigning land cover information, 
homogenous land cover types are first sampled on the multispectral image for their spectral identification or signature. These sample areas are also known as "training sites." (These spectral samples are synonymous with the clusters generated with ISODATA, only they are manually constructed.) With this collection of signatures and their associated land cover types already known (Table III), the maximum likelihood algorithm is used to match each multispectral raster cell in the image with the signature most similar to it (and the land cover type assigned to it). This strategy is often preferred to unsupervised because it allows for greater control of the spectral sample's statistics. (As each sample is taken, the statistics can be examined and the sample rejected if the standard is not met). This is important because of the need for the band values of each signature to have a small standard deviation and a normal distribution. However, this method can be difficult to use in an urban setting as it requires homogenous land cover of at least 2-3 acres to take a spectral sample.

\section{TABLE III}

EXAMPLE LISTING OF SPECTRAL SAMPLES AND CORRESPONDING LAND COVER TYPES ASSOCIATED DURING THE SAMPLING PROCESS

\begin{tabular}{cl} 
Spectral Sample & Land Cover Type \\
\hline Sample 1 & grass \\
Sample 2 & roof top \\
Sample 3 & deciduous forest
\end{tabular}


To summarize, the unsupervised method automatically generates homogenous spectral clusters, then land cover types are attached to each cluster. Supervised classification starts by first finding areas of homogenous land cover, then manually sampling spectral data to form spectral clusters later used to classify the image.

The heterogeneous nature of urban land cover makes supervised classification unworkable because of the need to have a 2-3 acre area of homogenous land cover to obtain a spectral sample (training site) of each land cover type. Because of this, the unsupervised strategy was determined to be most appropriate for this study.

\section{Step 3: Removing Nonvegetated Image Cells}

Satellite imagery examined as a whole can be viewed as a population of reflective energy measurements. The spectral variation of the population increases with the increased variation of land cover. For example, imagery of just forest land will have relatively low variation, while spectral measurements of urban lands has a high variation. Clusters of the spectral data, whether generated by the unsupervised method or sampled in the supervised method, are constructed for use in identifying targeted land cover types. An important characteristic of these clusters is that they have a statistically normal distribution and that the band ranges 
in each cluster (spectral response pattern) have relatively low standard deviations (SD). Clusters with low SDs are important because they provide increased certainty that the cluster will associate with only one of the targeted land cover classes and not be confused (or overlap) with clusters of other land cover types.

In the unsupervised method, the sizes of the SDs in each generated cluster are inversely related to the total number of clusters generated in the ISODATA phase. So, a large number of clusters will yield clusters with low SDs. The "cost" of lower SDs, however, is that large numbers of clusters require additional time and human effort to find and attach land cover types to.

A method used to reduce the number of clusters needed to produce clusters with low SDs is to first reduce the variation in the original image. Traditionally, this has been done by physically cutting the original imagery to the geographic extent of the study area, cutting the image to ecoregions if the study area covers a large area, or dividing the image among major landuses such as urban and rural. Whichever strategy is used, the goal is to reduce the image's spectral variation.

In this work, besides cutting the image to the project area (Figure 4), the spectral variation in the image was reduced by removing (or purging) spectral data that was not associated with any vegetation. This was done using a vegetation ratio of TM red and near infrared bands 3 and 4 (Figure 12) obtained from the satellite image and then "masking" out the non-vegetated cells. 


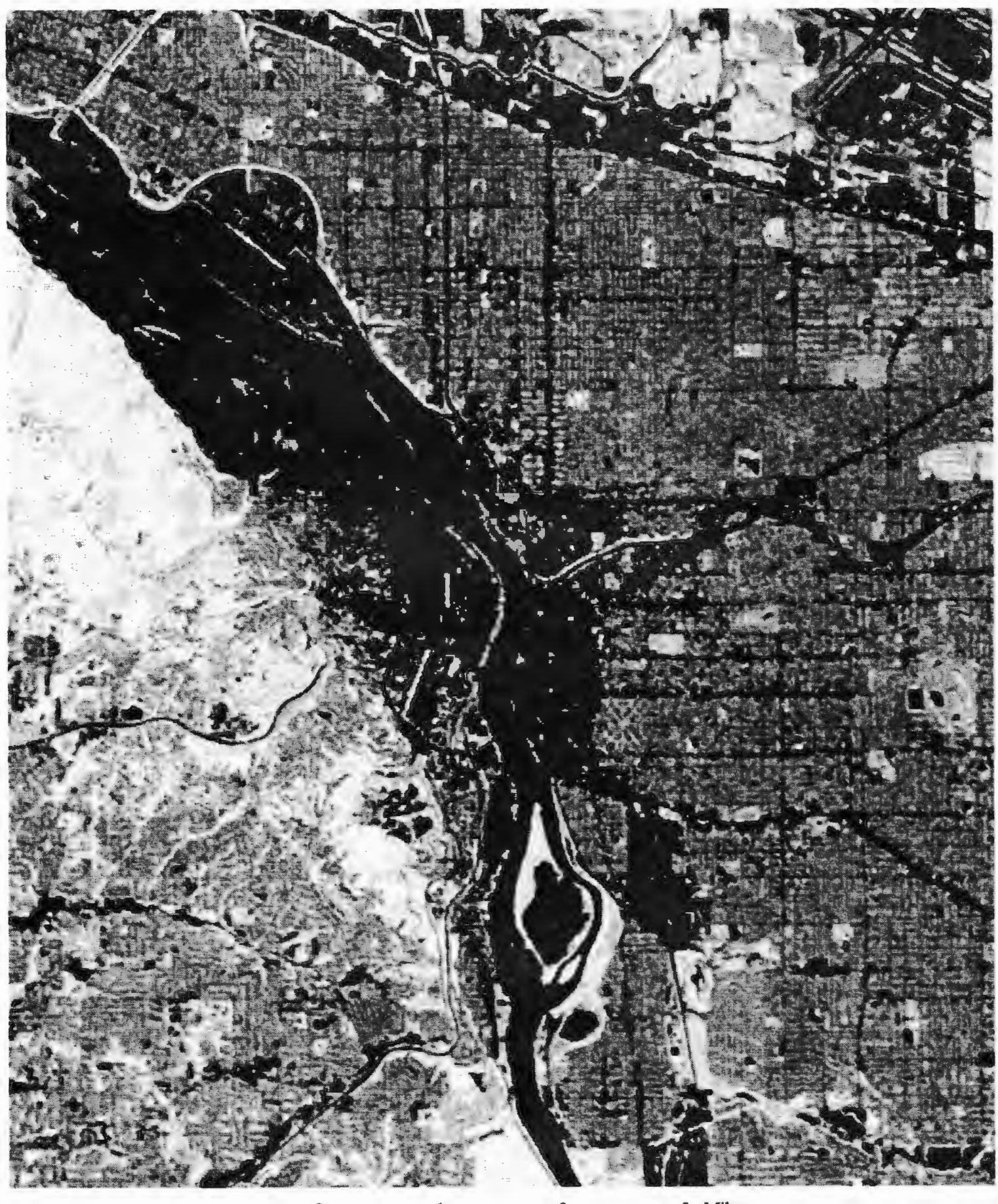
3 Miles

Figure 12. LANDSAT TM image of Portland, Oregon showing the results of a vegetation ratio (bands 3/4) and "purging" all non-vegetated cells. Black indicates areas of no vegetation. Gray tones indicate areas of varying intensities of vegetation (increasing lightness indicates more vegetation reflectance). 
The ratio band is an image enhancement technique that can make vegetation stand out more clearly due to vegetation's great capability of reflecting infrared energy, but absorbing visible energy (such as that in the red portion of the spectrum). With the ratio map, the "threshold" of where cell values no longer represented any level of vegetation was found by comparing the cell values to reference information obtained by interpreting CIR aerial photos for the presence of vegetation. Even where cells were partially vegetation and partially hard surface (Figure 13), this technique preserved cells even if a small portion of the cell covered live vegetation. All cells of complete water, soil, concrete or other hard surface were deleted from the multispectral image (Figure 14).

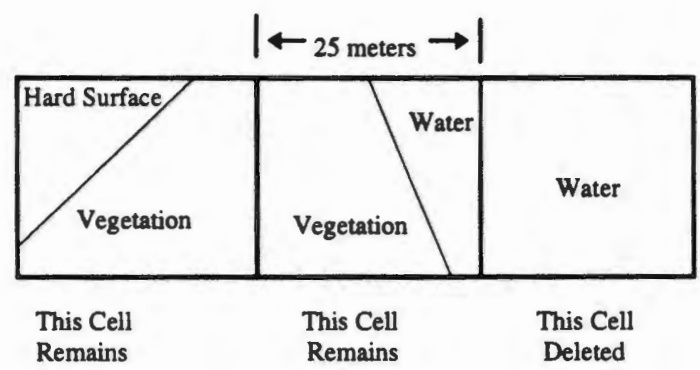

Figure 13. Raster cells, the land cover types they cover and what cells were deleted.

\section{Step 4: Spectral Stratification}

While removing non-vegetated cells from the image reduced spectral variation, a great deal of variation still remained. Urban vegetation cover ranges 


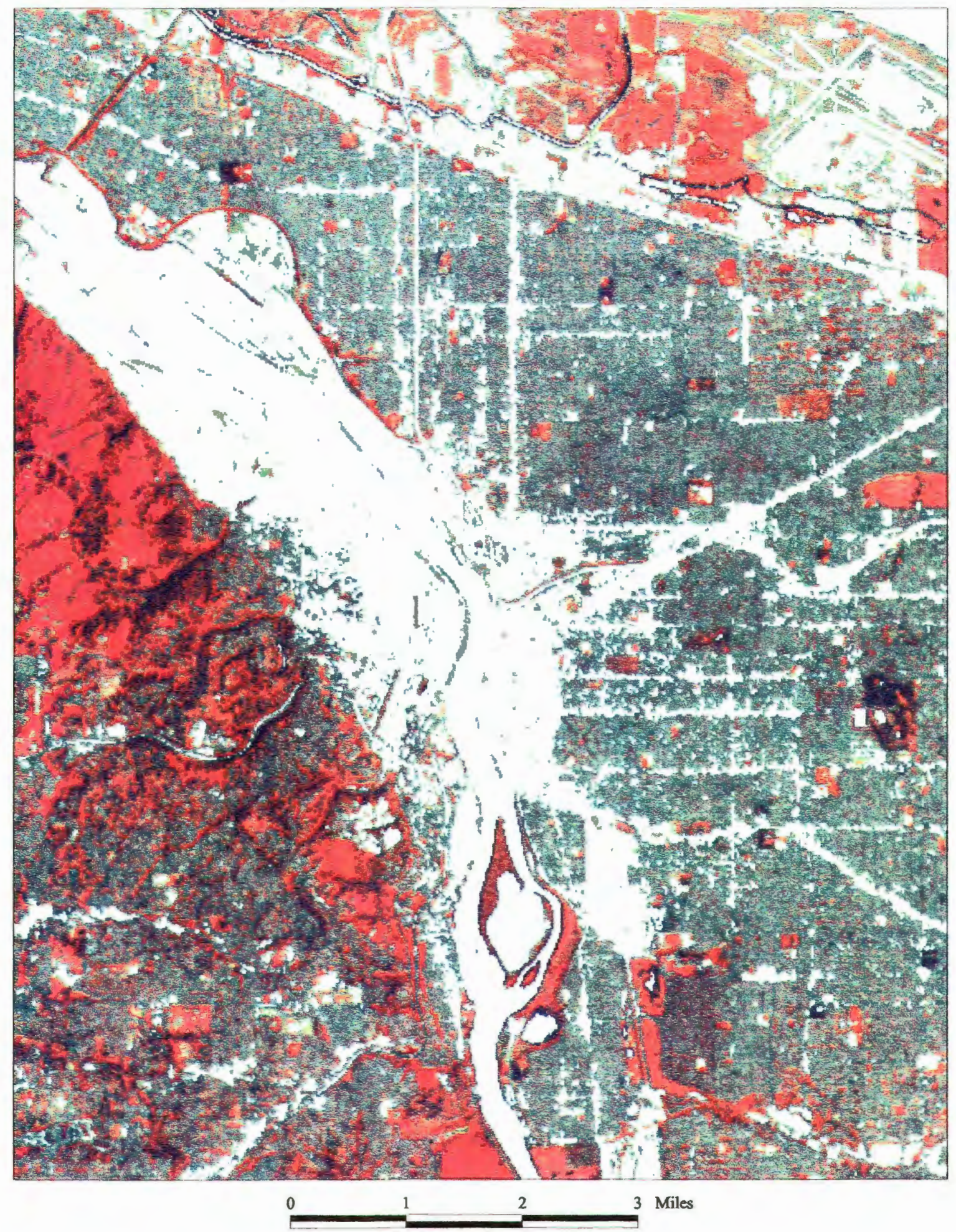

Figure 14. TM multispectral image with non-vegetated cells masked out. 
from stands of native forest to a single tree surrounded by pavement, from lush golf course grass to spots of dry grass closely surrounded by buildings. This variation in land cover naturally translates into variation in the image. To better manage the variation, the idea of spectral stratification was used.

Generally with geographic data, stratification means subdividing an area into continuous, homogenous units, such as forest stands. The idea of spectral stratification is to form subdivisions of relatively homogenous spectral data (Figure 15). When mapped, these subdivisions will not necessarily be in one

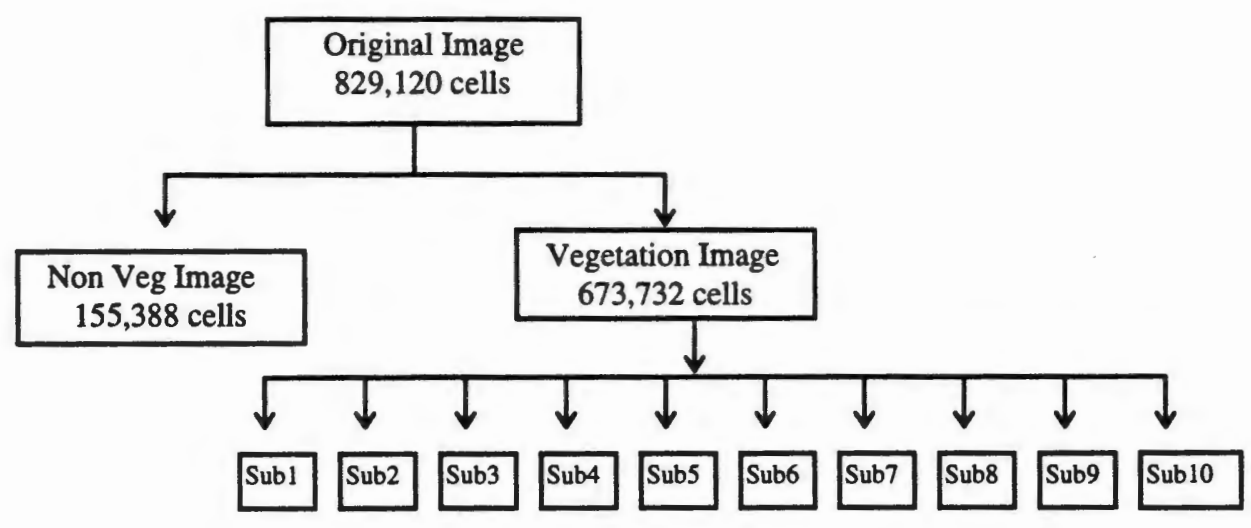

Figure 15. Spectral stratification within the multispectral image and the resulting subdivisions of the imagery.

continuous area, but each subdivision (or strata) will be spectrally similar. The usefulness of the subdivisions is that they can then be used to mask the original imagery for further unsupervised classification. 
The number of desired subdivisions of the vegetated image was chosen to be 10. This choice was guided by the goal of simply generating general clusters of conifer, deciduous, grass and mixtures of vegetation and hardsurface. Ten classes were chosen by roughly doubling the number of desired general vegetation classes.

To construct these subdivisions, 10 clusters were first generated from the spectral data by using the ISODATA algorithm. The output of this process was a signature file that represented the 10 relatively homogenous spectral clusters. Then, the maximum likelihood algorithm was used along with the signature file and the multispectral image of vegetation to produce a digital map of the 10 general classes (Figure 16). These classes represent the 10 strata (shown individually in Appendix A).

For a quick evaluation of general vegetation class separation, the mapped 10 general classes were compared to photo interpreted reference information and the general land cover types were assigned to each class. This showed that distinct groups of general vegetation were "broken out" (or separated). What follows is a listing of the general classes. Again, this is only an intermediate step on a path to a final, detailed classification. As can be seen in Table IV, the classes did "break out" the general land covers. In fact, the results show that fewer classes probably could have been used. 


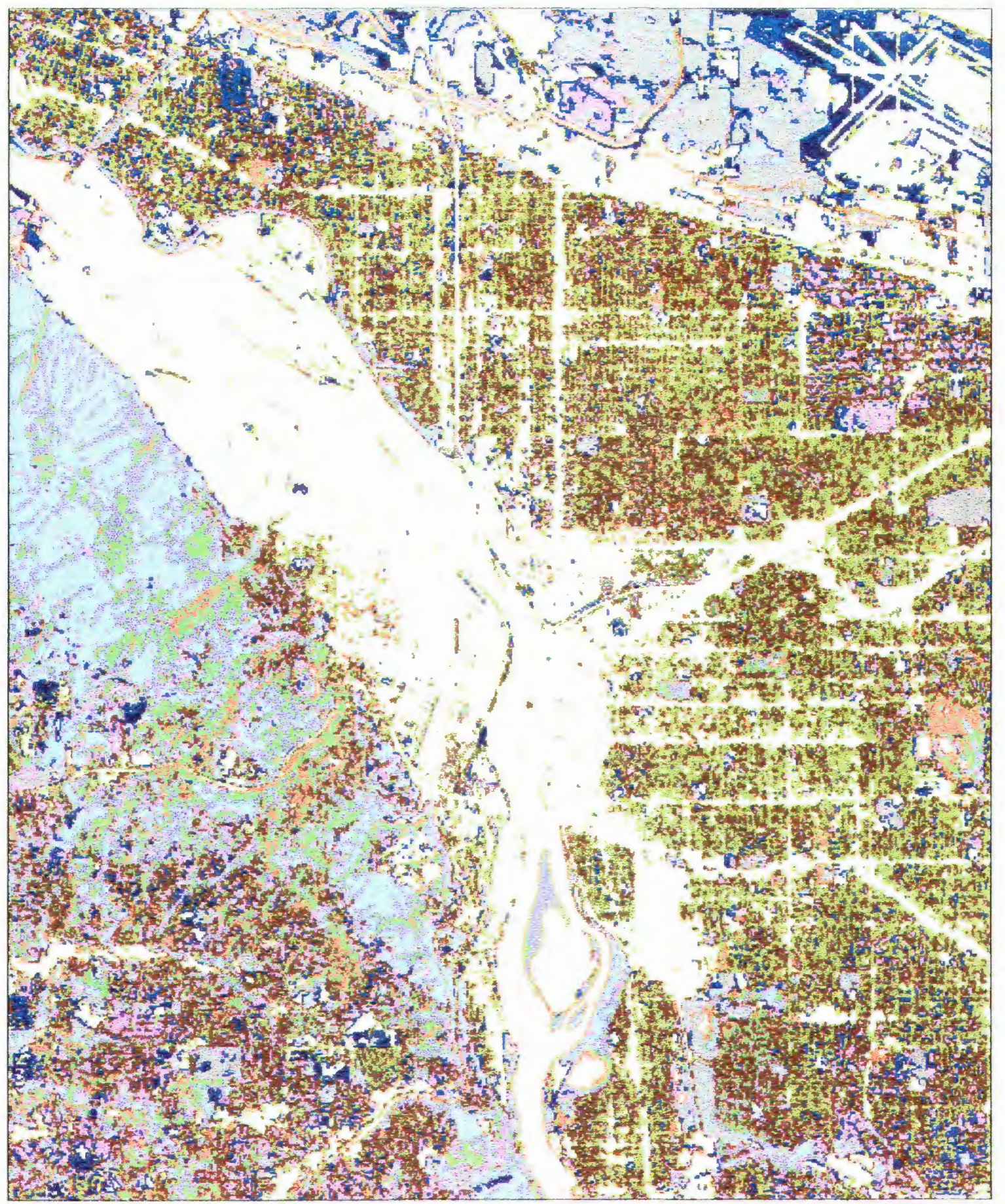
。 1 2 3 Miles

Figure 16. Classified map of 10 "general" classes. Constructed using unsupervised strategy. Each class is a "spectral strata" used later to subdivide the multispectral image. 


\section{TABLE IV}

\section{LISTING OF GENERAL VEGETATION CLASSES *}

\begin{tabular}{rlr} 
Class \# & General Land Cover Type & $\%$ cells \\
\cline { 2 - 3 } 1 & Conifer, shadow or waters edge & $4.2 \%$ \\
2 & Conifer, water's edge or vegetation with mixtures of hard surface & $7.5 \%$ \\
3 & Deciduous Forest & $10 \%$ \\
4 & Deciduous Forest & $12.1 \%$ \\
5 & Vegetation (grass and trees with mixtures with hard surface) & $11.6 \%$ \\
6 & Vegetation (grass and trees with mixtures with hard surface) & $16.9 \%$ \\
7 & Vegetation (grass and trees with mixtures with hard surface) & $18.8 \%$ \\
8 & Grass & $7.7 \%$ \\
9 & Grass (golf course) & $7.7 \%$ \\
10 & Grass & $3.5 \%$ \\
\hline & TOTAL & $100 \%$ \\
* This is not the final classification, but a general description \\
of cells that make up each strata.
\end{tabular}

As a final step in the stratification, the digital map of the 10 general classes was used to subdivide the vegetated multispectral imagery. Masking tools were used with each class to produce a computer file of multispectral measurements of only those cells within a particular general class. This process resulted in 10 files (one for each class) of multispectral imagery (Figure 17) where each file was a subdivision corresponding to the raster cells of its particular "general class." Each subdivided image was a strata because within each subdivision, the variation of spectral measurements was smaller than that of the entire vegetation image. 


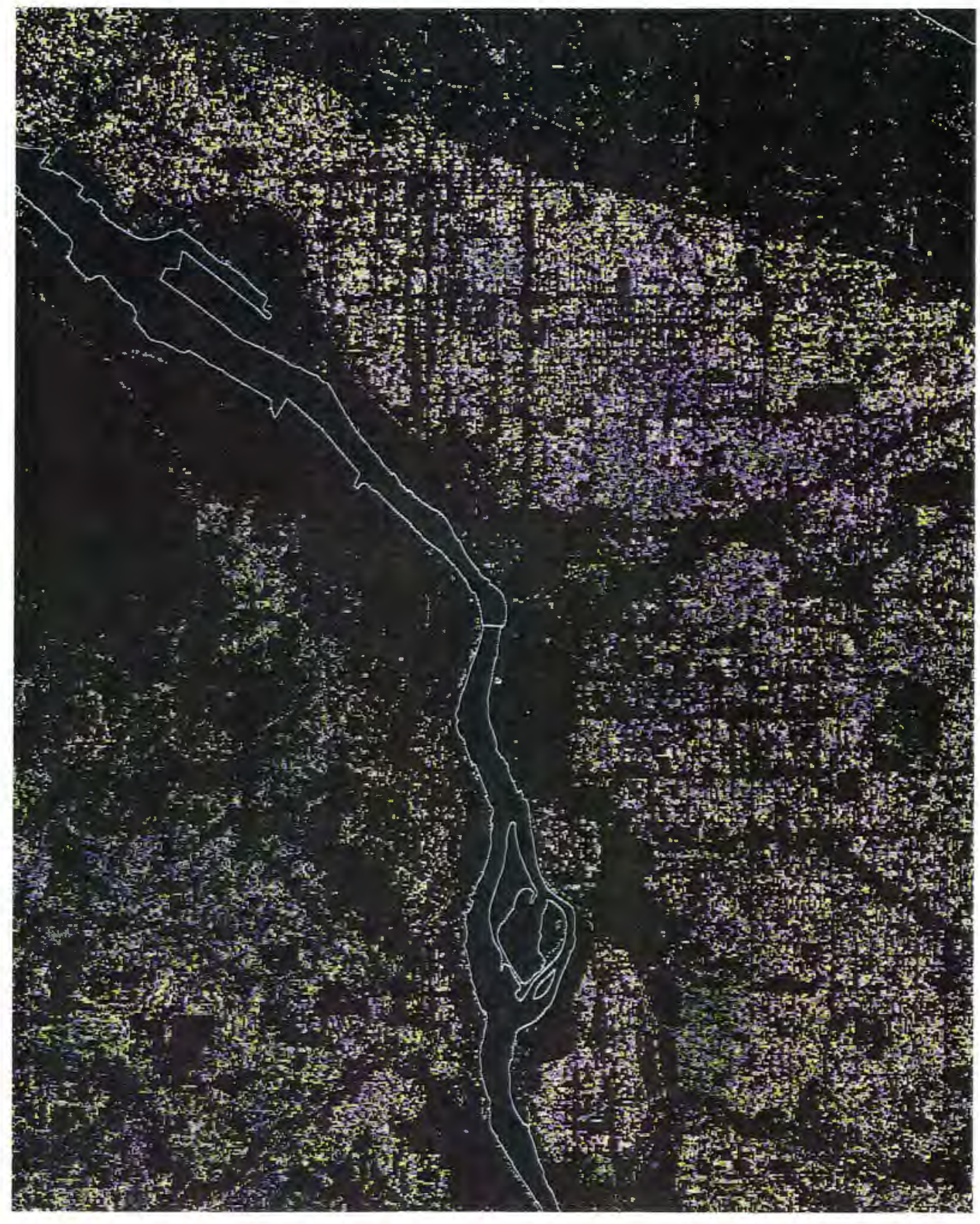

0

2

3 Miles

Figure 17. A masked TM multispectral image showing "spectral strata" or subdivision number "six" out of the ten "general" classes. The outline of the area's major rivers are shown in cyan. 
Step 5: Final Spectral Cluster Generation

Each of the 10 subdivisions was then processed with ISODATA to generate the final clusters for land cover classification. The number of classes generated for each subdivision varied from 20 to 40 . The number of clusters chosen for each image subdivision depended on the number needed to reach a standard deviation of 4 for each class.

The generated clusters (spectral response patterns) and their corresponding image subdivision (Figure 17) were used as input to a Maximum Likelihood classification algorithm to produce classified maps of each subdivision (where each class represented a spectral cluster). Then, land cover types were assigned to the classes of each of the 10 classified maps as the final step in the unsupervised method.

Two types of classes were used in the final classification. One for the amount of vegetation as defined by the amount of ground covered by vegetation. Classes Minor, Partial, Medium \& Full, along with their associated percentages are used to describe vegetation cover. The second type of class is "Vegetation Type" which is Conifer, Deciduous, Grass, or a combination. Table V displays the classes. The numbers in parentheses are the codes found on the raster map. 


\section{TABLE V}

\begin{tabular}{|c|c|c|c|}
\hline Minor $(<25 \%)$ & Partial $(25 \%-50 \%)$ & Medium $(50 \%-75 \%)$ & Full $(>75 \%)$ \\
\hline Mixed Vegetation (1) & $\begin{array}{l}\text { Grass (2) } \\
\text { Deciduous /Grass (11) } \\
\text { Deciduous (12) }\end{array}$ & $\begin{array}{l}\text { Grass (14) } \\
\text { Deciduous /Grass (4) } \\
\text { Deciduous }(5) \\
\text { Deciduous / Conifer (X) } \\
\text { Conifer (9) } \\
\text { Conifer / Grass (10) }\end{array}$ & $\begin{array}{l}\text { Grass (3) } \\
\text { Deciduous / Grass (13) } \\
\text { Deciduous (6) } \\
\text { Deciduous / Conifer (7) } \\
\text { Conifer (8) } \\
\text { Conifer / Grass (X) }\end{array}$ \\
\hline
\end{tabular}

* The " $\mathrm{X}$ " indicates the class was not used.

A full range of vegetation types was intended for the "Minor" column, but it was found that these classes were not discernible where vegetation coverage was less than $25 \%$. So, the vegetation types were collapsed into a general "Mixed Vegetation" class.

The greatest challenge in assigning land cover types to cluster classes was correctly associating a chosen geographic location on the map of cluster classes with the same geographic location on the reference information. In general terms, this is done by visually comparing the map of cluster classes with the reference data (an aerial photo) and finding the same location on each of them (Figure 18). If the cluster classes occur in large blocks of pixels, visual comparison can be easily performed. But if the cluster classes occur in small areas (salt and pepper patterns) then simply finding the location of a pixel on the photo can be difficult. The display scale of the two may be the same, but the rough resolution of the 

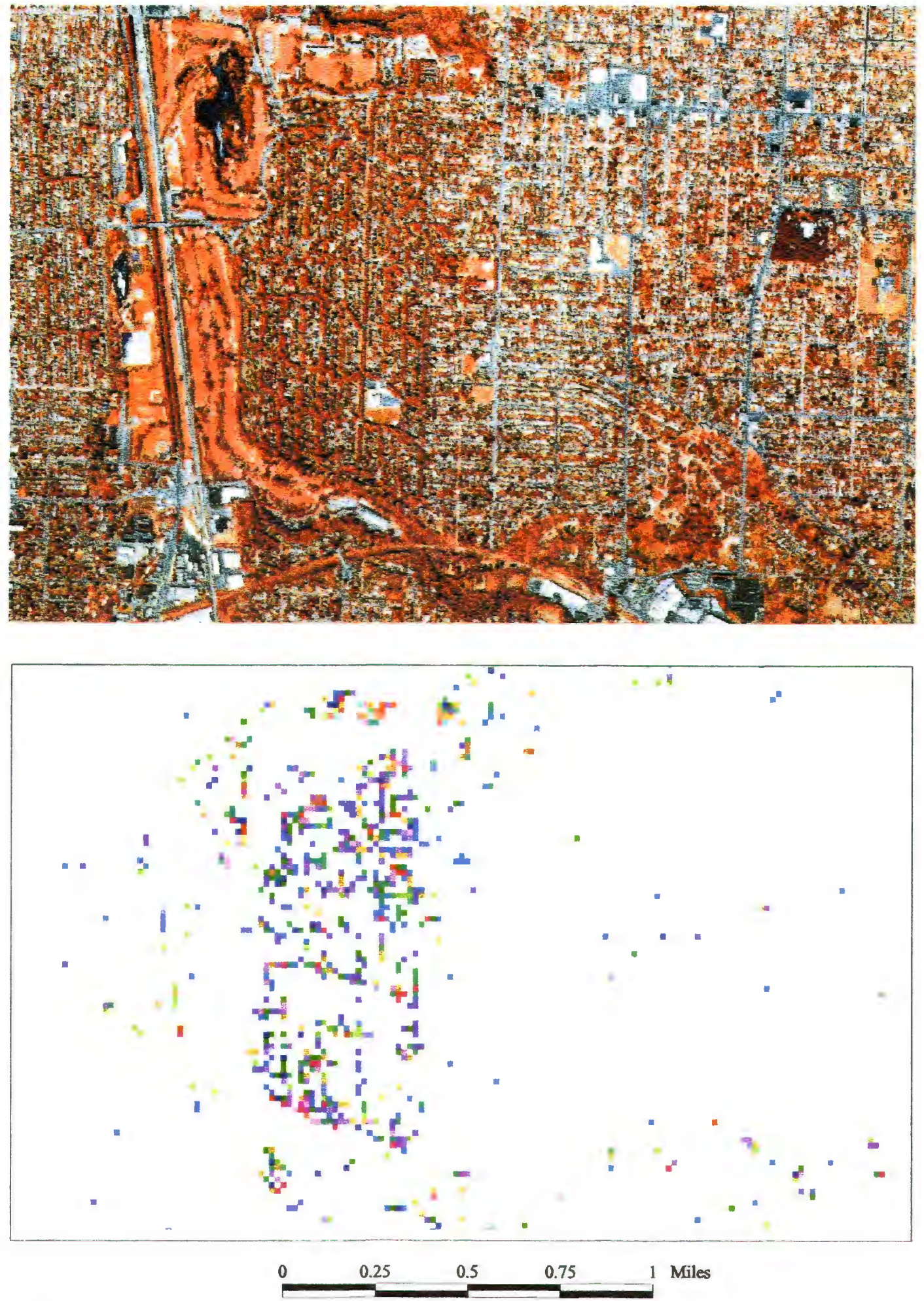

Figure 18. Color Infrared aerial photo (top) and a classified map from one of the 10 TM image "subdivisions" that cover the same area. 
cluster classes (25 meter cells) and the fine resolution of a photo makes it difficult to find landmarks to associate the same location. To aid the task, a GIS layer of city roads was laid on top of the map of cluster classes (Figure 19). This greatly aided the geographic association of ground truth and the cluster classes.

On a computer screen, each of the 10 cluster class maps were individually displayed with the city roads. Also, instead of showing all cluster classes, only one was shown at a time. Two or three samples of each cluster class were chosen. The same locations were then found on the aerial photo. Using a loupe (10x) or magnified stereo viewer, land cover information was interpreted from the photos and associated with the cluster class. To help view the photo's land cover as the satellite based sensor viewed land cover, a "fishnet" grid was constructed and plotted on mylar to place on the photo during interpretation. The grid spacing was 25 meters at the photo's scale (Figure 20). The examination of each cluster class at several locations confirmed a consistent land cover interpretation.

Viewing the photos with the magnifying glass and the fishnet grid did reinforce the fact that even within one raster cell, land cover is not homogenous. Often, tree and grass cover can be mixed together, or grass and roof tops, grass and pavement, etc. (Figure 21). When interpreting the land cover, judgments were made as to the percent coverage of vegetation and the dominant vegetation 

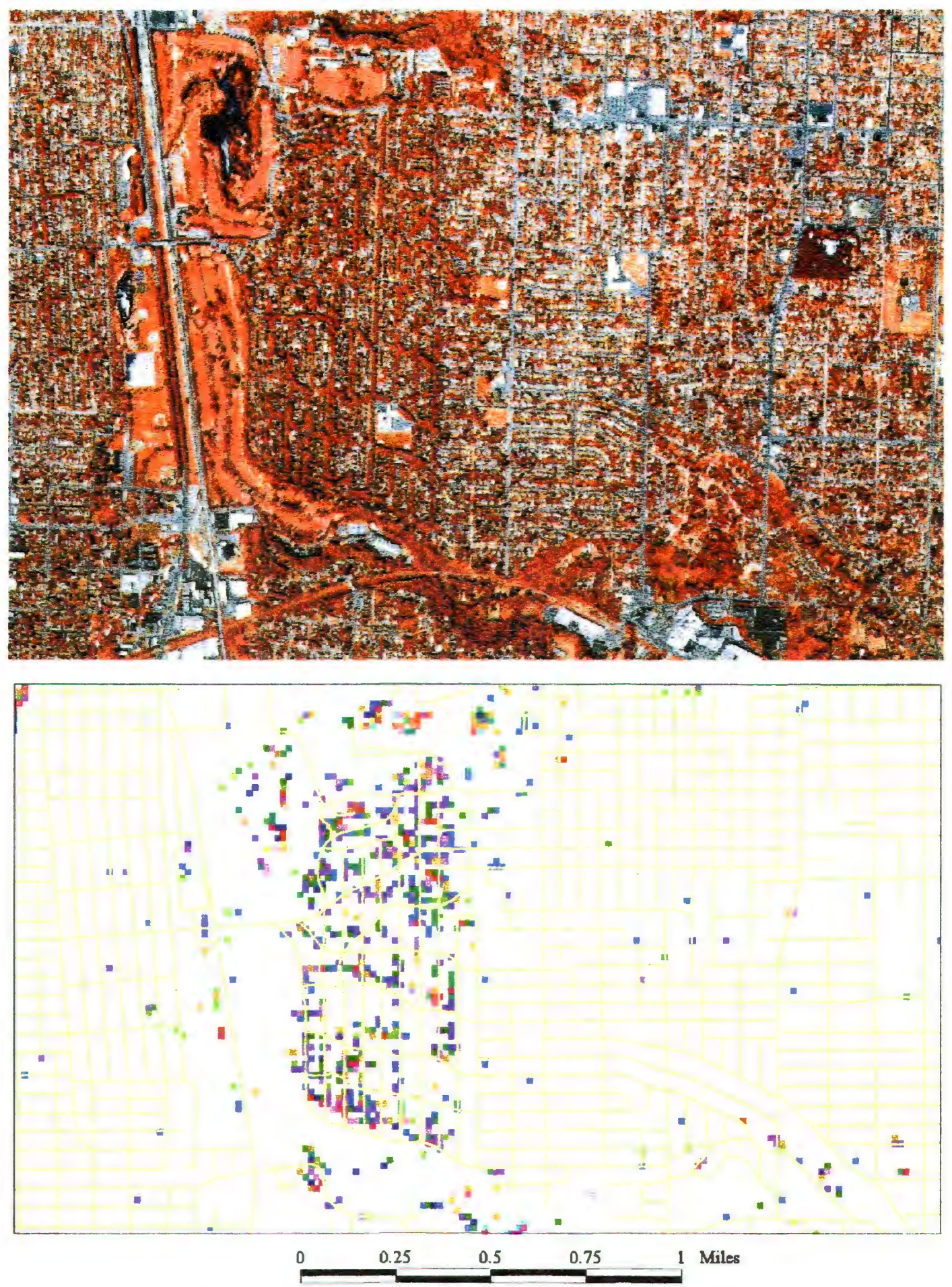

Figure 19. Classified map (of one of the 10 image subdivisions) with roads (yellow) overlaid to help reference the map with aerial photos. Each color indicates a different cluster class to which a land cover class was assigned using aerial photos as a reference source. 


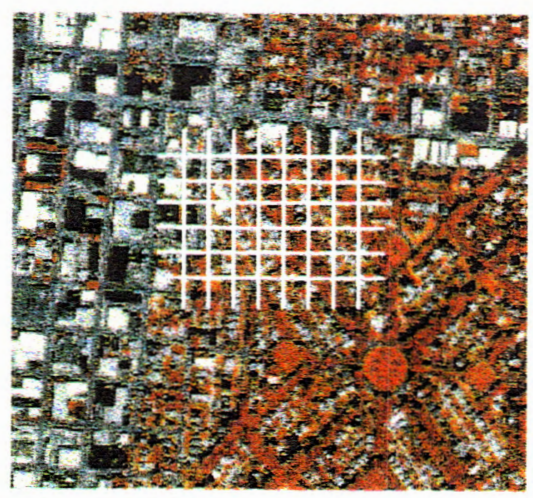

Figure 20. Example of fishnet grid used during photo interpretation. Cells represent 25 meters at photo scale. 
type (i.e., grass, deciduous, conifer). If no vegetation type was deemed dominant, it was called a mixture.

25 meter cells

\begin{tabular}{|l|l|l|l|}
\hline Hard Surface & Water & \\
vegetation & vegetation & Water \\
\hline
\end{tabular}

Figure 21. Example of raster cells covering mixtures of vegetation and hard surface.

\section{Step 6: Assembling the Final Vegetation Map(s)}

Once all cluster classes of the 10 digital maps had land cover types associated with them, the 10 were merged into a single file to produce a complete digital map of vegetation-based land cover types. This completes the process and makes the digital maps ready for use in a Geographic Information System which opens an additional realm for analysis, manipulation, and display of the data.

\section{SUMMARY STATISTICS AND MAPS}

Table VI displays the final vegetation classes with each map class's acreage within the study area (image area). (See Appendix B for summary statistics and maps covering just the City of Portland, Oregon.) 


\section{TABLE VI}

\section{FULL LISTING OF VEGETATION BASED LAND COVER CLASSES WITH ACREAGE REFLECTING CLASS COVERAGE FOR THE IMAGE AREA COVERING THE CITY OF PORTLAND, OREGON}

\author{
Vegetation Class \\ Non-Vegetated Land Cover \\ Water \\ Other \\ Minor $(<25 \%)$ \\ Mixed Vegetation (1) \\ Partial (25\%-50\%) \\ Grass (2) \\ Deciduous /Grass (11) \\ Deciduous (12) \\ Medium $(50 \%-75 \%)$ \\ Grass (14) \\ Deciduous /Grass (4) \\ Deciduous(5) \\ Deciduous / Conifer (X) \\ Conifer (9) \\ Conifer / Grass (10) \\ Full $(>75 \%)$ \\ \begin{tabular}{l} 
Grass (3) \\
Deciduous / Grass (13) \\
Deciduous (6) \\
Deciduous / Conifer (7) \\
Conifer (8) \\
Conifer / Grass (X) \\
\multicolumn{1}{c}{ Total }
\end{tabular}
}

\section{Percentage \\ Acres of Area}

$\begin{array}{rc}8,512 & 7 \% \\ 15,466 & 12 \%\end{array}$

$10,084 \quad 8 \%$

$15,644 \quad 12 \%$

$10,837 \quad 8 \%$

$2,048 \quad 2 \%$

$\begin{array}{rc}713 & 1 \% \\ 11,997 & 9 \% \\ 11,531 & 9 \% \\ 0 & 0 \% \\ 2,333 & 2 \% \\ 324 & <1 \%\end{array}$

\begin{tabular}{rc}
16,477 & $13 \%$ \\
3,551 & $3 \%$ \\
13,161 & $10 \%$ \\
3,664 & $3 \%$ \\
1,686 & $1 \%$ \\
0 & $0 \%$ \\
\hline 128,028 & $100 \%$
\end{tabular}

Notice that the classification scheme covers two major areas: vegetation amount and vegetation type. Classes belonging to these two major areas were separated into two distinct maps. What follows are Figures 22, 23, 24, 25 that display these two maps for Portland, Oregon. 


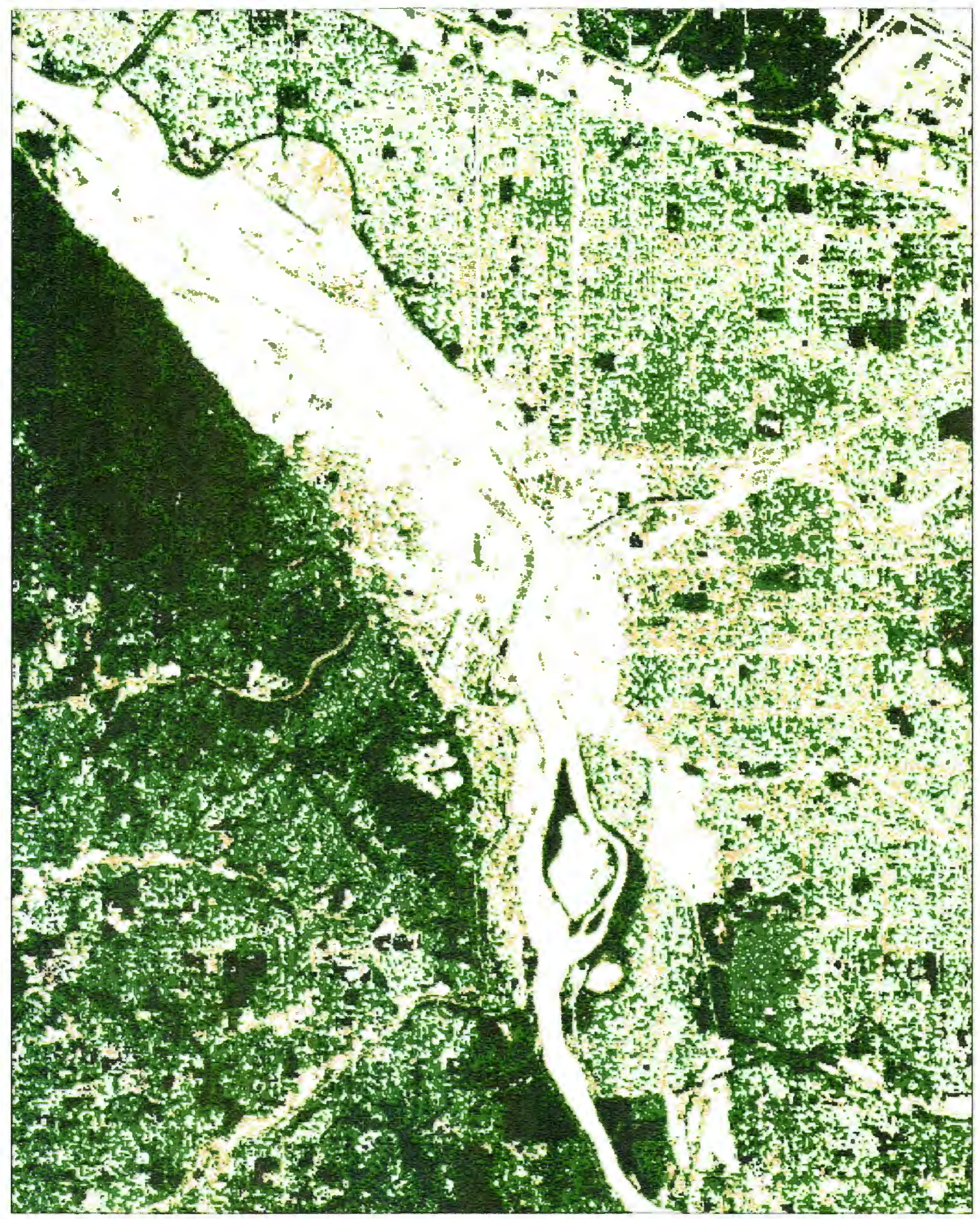
2 3 Miles

Vegetation Amount

Figure 22. The percent of vegetative cover in the central portion of Portland, Oregon. Vegetation includes grass where open fields of grass can be classified as $>75 \%$ coverage.

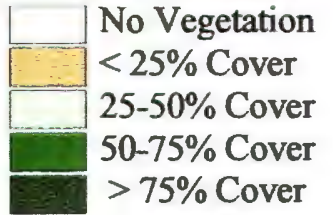




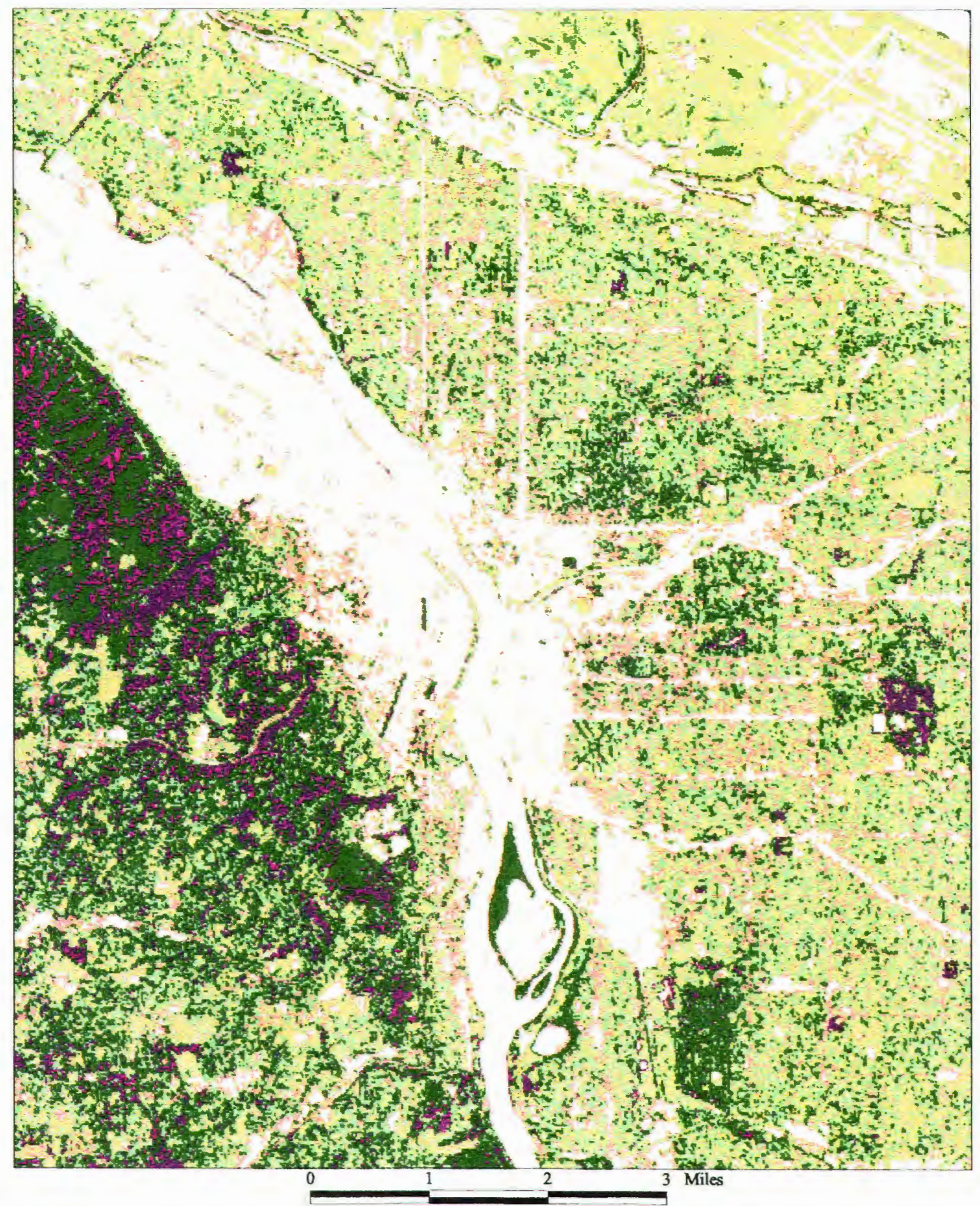

Figure 23. Vegetation Types in the central portion of Portland, Oregon.

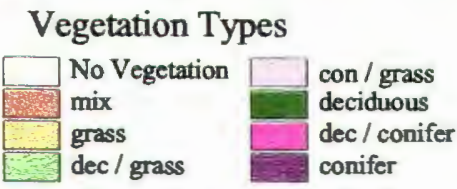




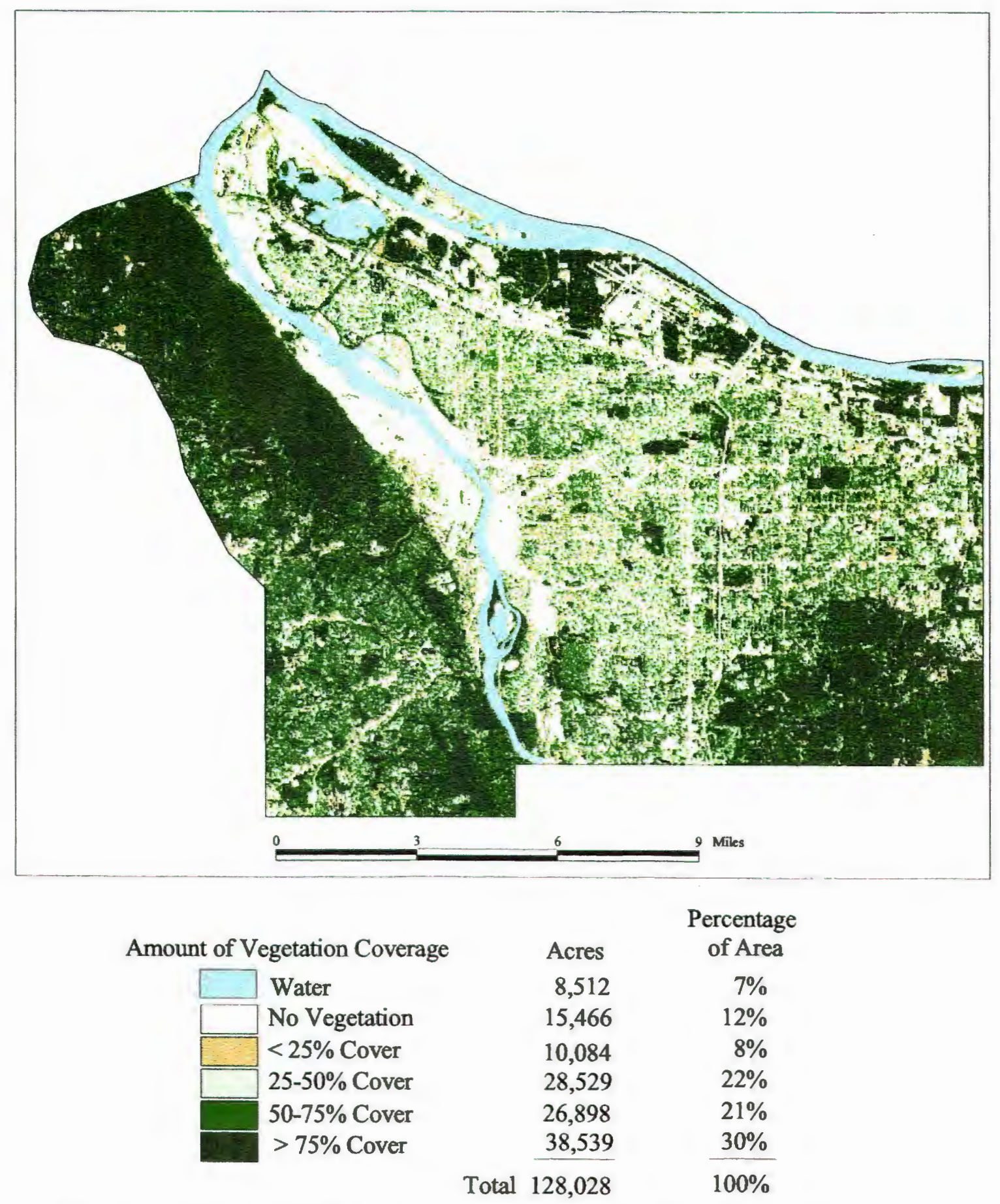

Figure 24. Mapped amounts of vegetation coverage with associated acres and percentage of area for the image area covering the City of Portland, Oregon. Vegetation cover includes grass. Therefore, areas that have $>75 \%$ vegetation cover may be areas of grass. 


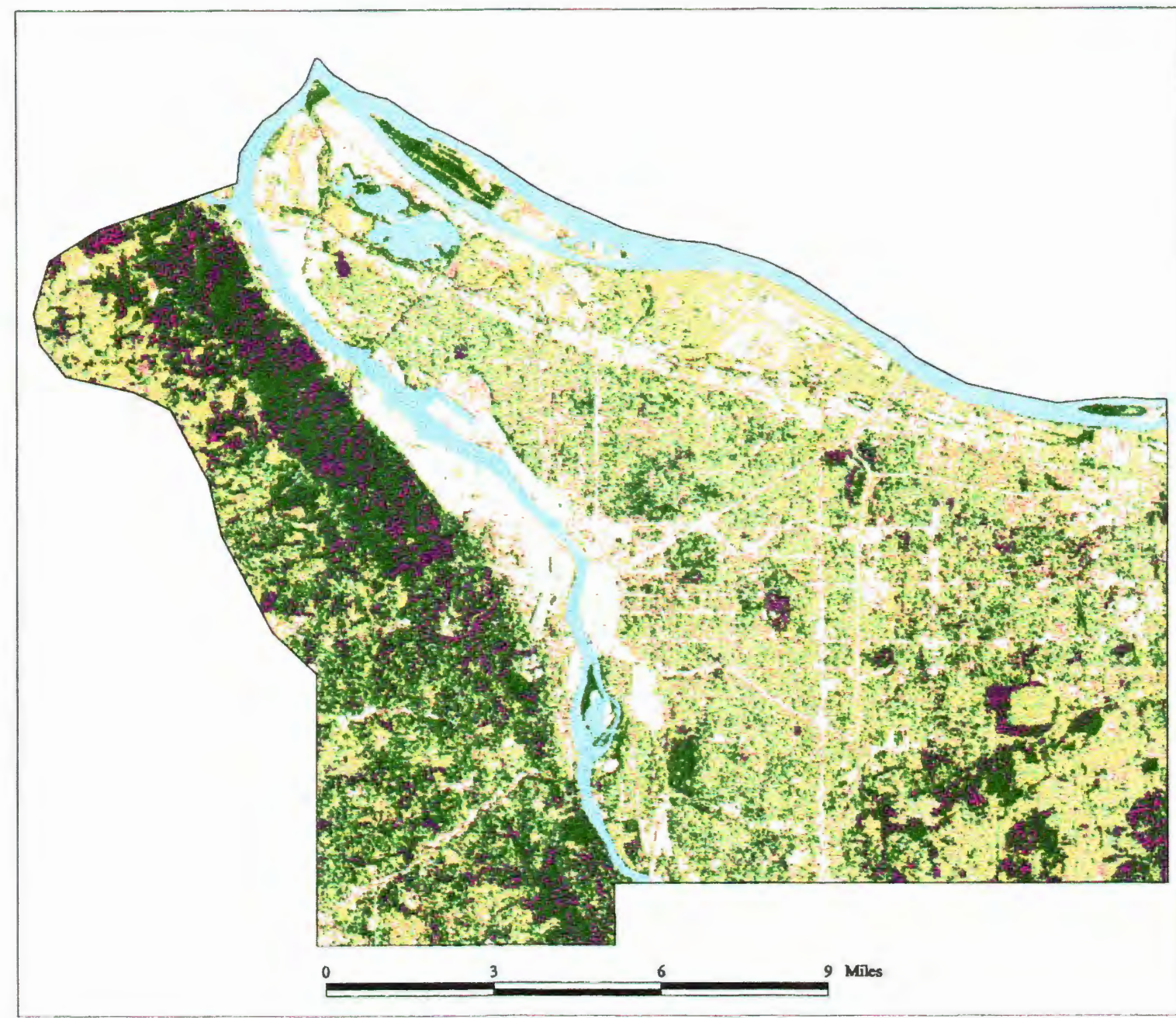

\begin{tabular}{|c|c|c|}
\hline VegetationTypes (and water) & Acres & $\begin{array}{c}\text { Percentage } \\
\text { of Area }\end{array}$ \\
\hline Water & 8,512 & $7 \%$ \\
\hline No Vegetation & 15,466 & $12 \%$ \\
\hline Mix & 10,084 & $8 \%$ \\
\hline Grass & 32,834 & $26 \%$ \\
\hline Deciduous / Grass & 26,385 & $20 \%$ \\
\hline Conifer / Grass & 324 & $<1 \%$ \\
\hline Deciduous & 26,740 & $21 \%$ \\
\hline Deciduous / Conifer & 3,664 & $3 \%$ \\
\hline Conifer & 4,019 & $3 \%$ \\
\hline Total & 128,028 & $100 \%$ \\
\hline
\end{tabular}

Figure 25. Mapped vegetation types with associated acreage and percent of area for the image area covering the City of Portland, Oregon. The acreage should be interpreted as the amount of land containing a variable amount of vegetation coverage. For example, the grass category may include mixtures of grass and concrete. So, it would not be accurate to conclude that there are 32,834 acres of solid grass. Instead, it would be accurate to conclude that there are 32,834 acres with an amount of grass ranging from $1-100 \%$ coverage. 


\section{CHAPTER IV}

\section{ACCURACY ASSESSMENT}

\section{ASSESSING TWO MAPS}

The previous chapter described the process of preparing two maps representing the amount of vegetation cover and the type of vegetation for the City of Portland, Oregon from satellite imagery. As with any type of mapping, the results from computer-based image analysis can contain error. Therefore, it is important that the image classification method that produced these maps be assessed for accuracy. When assessing the accuracy or correctness of a map, the general method is to compare each class on the map against a sample of reference data (which is assumed to be correct) for the same area covered by the map. In this thesis, the reference data was CIR aerial photos of a scale of $1: 24,000$. These photos were acquired in 1991, making them nearly identical in time with the 1991 imagery used for this work.

Accuracy assessment can be approached either visually or statistically. In the visual approach, a comparison can be performed between the map and the reference data, seeking to identify general similarities and differences. When 
comparing each of the two vegetation maps with the reference data, there were definite similarities. Where the amount of vegetation cover was visually sparse on the aerial photo, it also appeared sparse on the map (figure 26). Vegetation types such as deciduous, conifer, grass, and mixtures also exhibited similarities between the photo and map (figure 27). Visual inspection also revealed errors in some areas, such as along rivers banks where deciduous trees were misclassified as conifer.

Despite its simple and intuitive usefulness, the visual method has definite shortcomings. The primary issue relates to subjectivity and reliability. One person's visual assessment may conclude "high" accuracy while another person's assessment may conclude "low" accuracy. Who is correct? Also, a person may be inclined to only examine an area with which he or she is familiar, rather than obtain a sense for the entire map. It is also difficult to use this method to assess how well each individual class predicts the vegetation. For example, class A may be judged to be correct more often than Class B and class C, and class B may be correct more often than class $\mathrm{C}$. Is the difference between $\mathrm{A} \& \mathrm{~B}$ greater than between B \& C?

To avoid the inherent subjectivity of a visual assessment, a statistical assessment was also performed. The advantages of the statistical assessment are several. First, an assessment replaces the imprecise "high" or "low" accuracy 

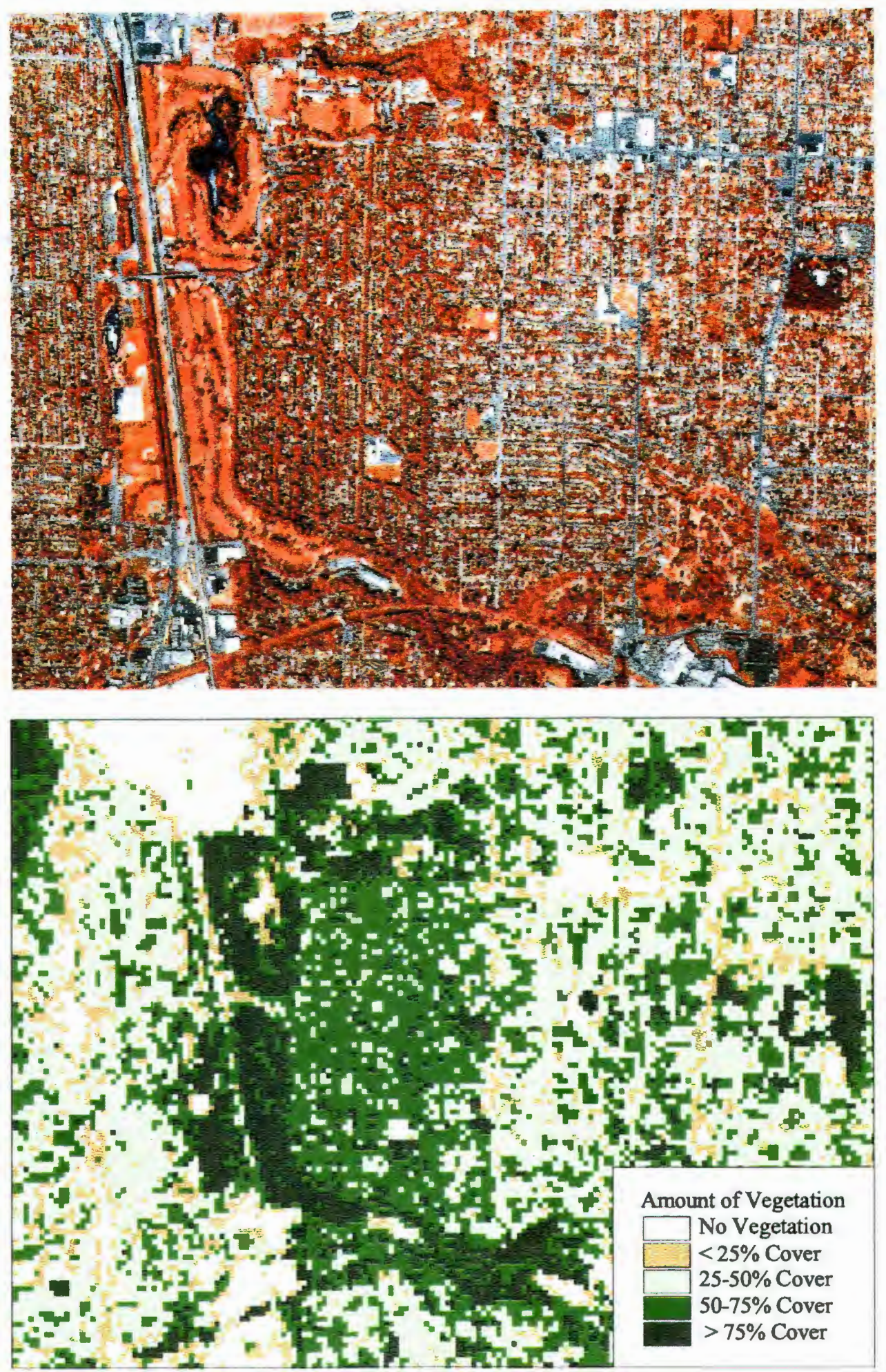

Figure 26. A visual comparison of reference data (CIR aerial photo) and the classified image showing the amount of vegetation. 

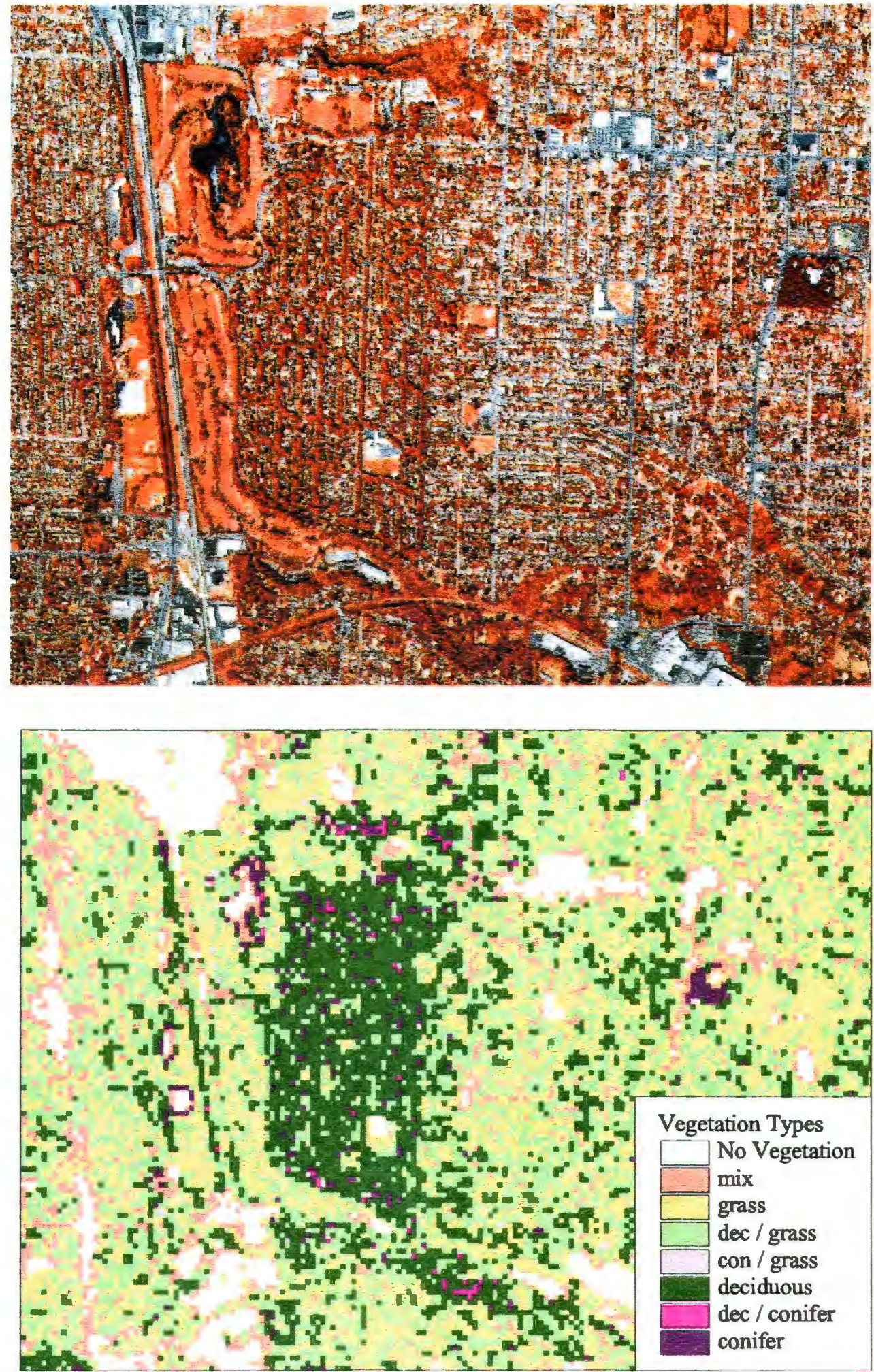

Figure 27. A visual comparison of reference data (CIR aerial photo) and the classified image showing the type of vegetation. 
judgments with a numerical estimate of map correctness. Second, it indicates the correctness of each map class and reveals classes that are difficult to distinguish, or separate from each other, using this study's image classification methods. Third, it yields an indication of what classes may be over-allocated or underallocated, thus providing clues about how to improve the classifications.

This chapter will focus on the details of the quantitative accuracy analysis and present the results of the analysis. Following this, sources of likely error will be discussed along with how these sources of error not only influenced the vegetation map construction, but also the sampling for quantitative assessment. Finally, methods to possibly further reduce error if this work were done again will be presented.

\section{SAMPLING}

A significant portion of mapping and remote sensing literature focuses on accuracy assessment and provides guidelines for sampling strategy and sample size determination, as well as presentation and analysis of the results (e.g., Hord and Brooner, 1976; van Genderen and Lock, 1977; Hay, 1979; Ginevan, 1979; Congalton, 1988; Campbell, 1996). The work presented here will be based on the recommendations presented in these papers. 
Accuracy assessment is the task of comparing a map against reference data. Ideally, this would involve comparing the maps produced in this work against other full maps of the same vegetation classes covering the study area. However, such maps are not available; and if they were, there would be little need for this classification research. In place of a full reference map, vegetation cover was sampled at point locations on larger scale, and therefore, more detailed air photos. At each sample location, a judgment was made of the amount of vegetation and vegetation type and using the same vegetation classes employed on the digital maps. Once established, the samples were compared to both vegetation maps to estimate their accuracy.

\section{Sampling Strategy}

Sampling strategy focuses on how the locations of sample points are selected. Alternatives for selection include random, systematic, random stratified, and systematic-stratified. Many researchers, including both Hay (1979) and Congalton (1988) recommend a stratified random approach where a desired number of sample points are generated within each map strata or class. An advantage of this method is that it assures that all map classes are well represented in the sample while using a minimum number of sample points. This strategy was chosen for this work. 


\section{$\underline{\text { Sample Size }}$}

The next step in the process of accuracy assessment is to determine the number of sample points needed to produce a reasonable assessment. When choosing the number of sample points, there is no absolute "correct answer," though, in general, the larger the sample, the greater the reliability of conclusions based on the sample. The sample size question is more often a matter reaching a compromise between cost (the number of sample points) and the confidence interval desired from the answer. Confidence interval specifies the accuracy range within which the true answer is likely to be found and is calculated using the formula for Standard Error for binomial data (Figure 28, Part A).

For example, consider a situation where from a sample of 50, a particular map class was found to be correct at 40 observations, or $80 \%$ of the time.

(Correct means that when compared, the map class for the sample site and the map being assessed agree.) Assuming a confidence limit (CL) of $95 \%$, the confidence interval for this result would be $80 \%+/-11 \%$ (Figure 28 , Part B). This means that the map user can be $95 \%$ confident that the level of correctness for the particular class lies somewhere in the range between $69 \%$ and $91 \%$ correct. Continuing the example, if more samples were established, such as 100 , the confidence interval would narrow to $+/-8 \%$ (i.e., $72 \%$ to $88 \%$ ) given the same result of $80 \%$ correct (Figure28, Part C). 


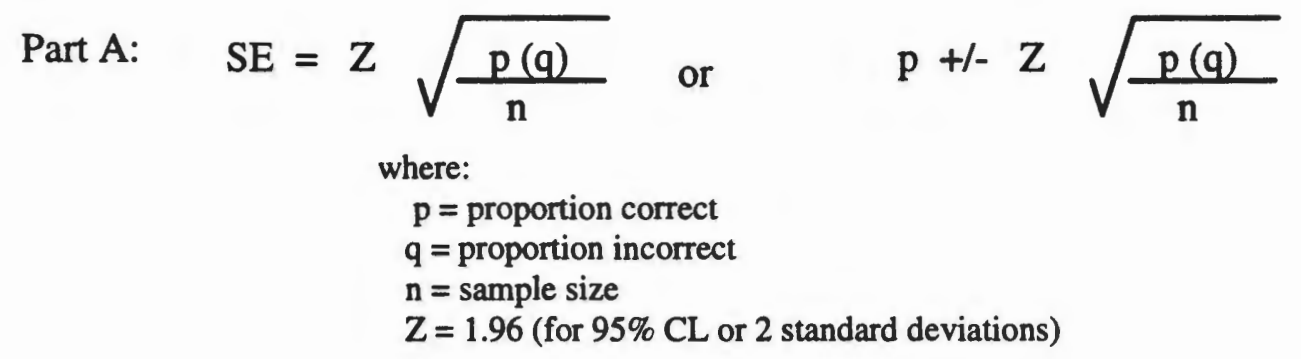

Part B: $\quad$ Confidence interval with a sample of 50 :

$$
0.8+/-1.96 \sqrt{\frac{0.8(0.2)}{50}}=80 \%+/-11 \%
$$

Part C: $\quad$ Confidence interval with a sample of 100 :

$$
0.8+/-1.96 \sqrt{\frac{0.8(0.2)}{100}}=80 \%+/-8 \%
$$

Figure 28. The formula for Standard Error is shown along with its use to determine the Confidence Interval.

The size of a confidence interval is also a function of the proportion of correct samples. For a given sample size, the confidence interval narrows as the proportion of correct samples increases. So, the more accurate the map, the fewer samples are needed to reach a desired confidence interval.

For assessing map class correctness, Hay (1979) recommends 50 samples per map class as an absolute minimum. A key assumption of this method is that the errors are normally distributed. This will not likely be the case if the sample is less than 50. This guideline of 50 samples (minimum) was accepted for this 
project. With the vegetation type map having 8 classes (including no vegetation), the total sample size was 400 points. The same sample points were used on both the vegetation type and vegetation amount maps.

Figure 29 displays a flow chart that summarizes the next steps of sampling for accuracy assessment.

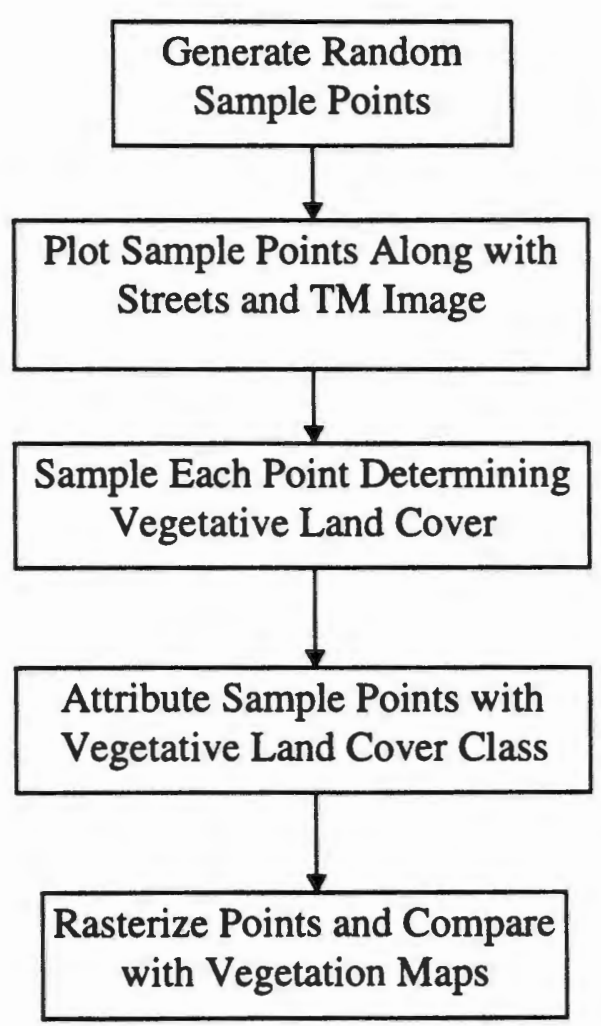

Figure 29. Flowchart summarizing steps to obtain reference data for comparison against the classified maps of urban vegetation. 
Generation of Stratified Random Points

Geographic Information System (GIS) software (ESRI's ARC/INFO) was used to construct all sample points within the project area (Figure 30). To do this in a stratified random manner, raster map management tools (GRID) were used to isolate each class and then choose 50 raster cells at random within just that class. After the random cells were chosen for each class, they were converted to vector points and appended into one GIS map (layer) of 400 points.

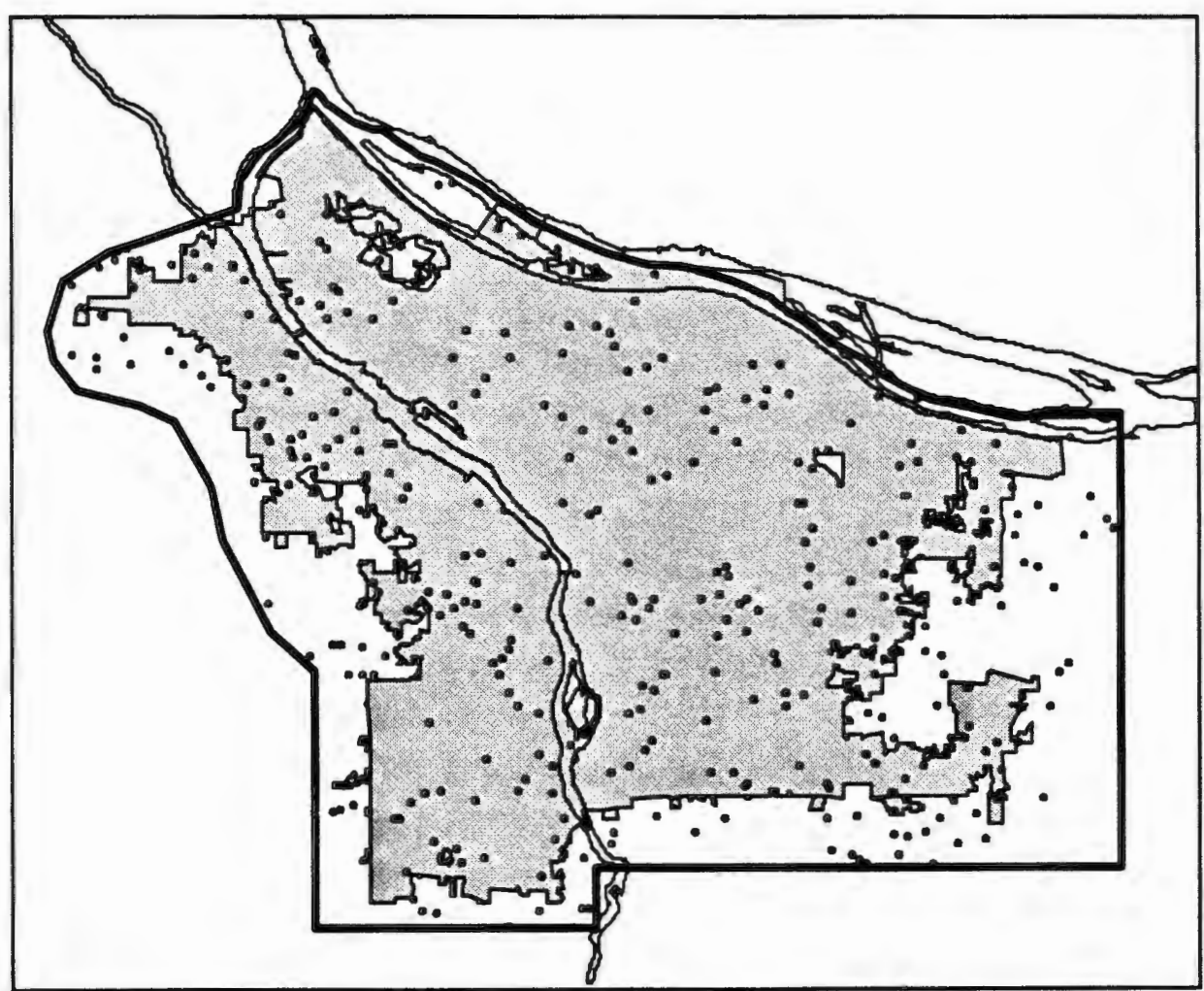

Figure 30. Portland (in gray), the study area boundary (bold line) and random sample points (black dots). 


\section{Determining Land Cover at Sample Locations}

Vegetated land cover (type and amount) at each sample point location was determined in the same manner as it was determined for the image classification work. Sample points and their unique ID numbers were plotted along with streets and the unclassified TM image. Both the streets and the unclassified image were used to help find the proper position of the sample point on the CIR aerial photo, which provided the reference data. Photo interpretation was done using a 10x loupe.

The intention of the sampling was to "blindly" determine (without consulting vegetation maps) the vegetative land cover of the sample point (using the photos) and then compare it to the two full maps of urban vegetation. It could be argued that using the unclassified TM image as a backdrop to the sample points could reduce the validity of "blind sampling". However, the image played an important role in finding the location of the sample point on the photo. Without it, significant error would have been introduced by sampling the wrong location.

As with the original image classification work, a grid (on mylar) representing the TM cells was laid on top of the CIR photos during interpretation to help gauge how the satellite "sees" the ground and to aid in finding the pixel representing each sample point. For each point, vegetative land cover (both vegetation amount and type - according to the classification scheme) was recorded 
along with the point's identification number. The data was then entered into the point layer's attribute table.

\section{Comparison of Samples and Maps}

When all the points were sampled and vegetated land cover classes attached as attributes, the GIS point layer was converted back to a raster format where each point was represented by a raster cell. Other raster cells were NODATA (null). The raster file of samples was then "combined" in GRID with the full vegetation raster files.

Unlike traditional raster formats where only one attribute can be associated with each cell, GRID allows multiple attributes to be attached, so, the results of the GRID "combine" stored both the vegetative class from the original map and the sampled vegetation data. This allowed easy comparison of the two within a database environment.

\section{ERROR MATRICES}

The error matrix, the standard method to report accuracy assessment, "is required for any serious study of accuracy" (Campbell, 1996; Jensen, 1996). This tabular display compares the classes of the "map to be evaluated" with the "reference data obtained from sample points". The matrix generally has reference 
classes listed in rows and the digitally-derived classes listed in the columns. Thus, in the example shown in Table VII, there were 34 pixels that the reference data says belong in Class $\mathrm{A}$ that were correctly put in Class $\mathrm{A}$ by the digital analysis, and one incorrectly placed in class B and one in Class C. A primary component of the error matrix is the diagonal line of cells. These cells display the number of sample points whose vegetative land cover classification was placed in the correct class on the digitally interpreted map. These values are summed in the lower right cell.

\section{TABLE VII}

\section{EXAMPLE ERROR MATRIX *}

\begin{tabular}{|c|c|c|c|c|c|}
\hline \multirow{5}{*}{$\begin{array}{l}\text { Reference } \\
\text { data from } \\
\text { sample } \\
\text { points }\end{array}$} & \multicolumn{5}{|c|}{ Map Classes being evaluated } \\
\hline & & Class A & Class B & Class C & Total \\
\hline & Class A & 34 & 1 & 1 & 36 \\
\hline & Class B & 3 & 45 & 3 & 51 \\
\hline & Class C & & 2 & 56 & 58 \\
\hline & Total & 37 & 48 & 60 & 135 \\
\hline
\end{tabular}

*Diagonal Cells Highlighted

The accuracy results for each map class are also represented by the “producer's accuracy" (PA\%) and “consumer's accuracy" (CA\%) (Campbell, 1996), standard errors (confidence interval) for the PA\% \& CA\%, as well as the errors of omission and commission for each class. 
The consumer's accuracy "forms a guide to the reliability of the map class as a predictive device" (Campbell, 1996). It tells the user what percent of the areas placed in a particular class by a digital analysis, actually corresponds to that class on the ground. It thus indicates to the map user or "consumer," how reliable a map is on a class-by-class basis. The producer's accuracy, on the other hand, indicates how much of the "true" land cover classes were actually mapped by the classification process. It thus indicates to the map maker or "producer," how good a job has been done in capturing each of the correct classes.

In a statistical sense, to take the percentages of consumer's and producer's accuracy as absolute answers would be incorrect. The results represent a likely average level of certainty with a corresponding confidence interval, or range within which the real level of likely correctness falls.

Closely related to the consumer's and producer's accuracy are the errors of commission (EC\%) and errors of omission (EO\%). These measures estimate how much was left out of each class (omitted) and how much "error" was assigned to each class (committed). They can be thought of as the opposite of consumer's and producer's accuracy because they are inversely related to the CA\% and PA\%, respectively. (In other words $\mathrm{EC} \%+\mathrm{CA} \%=100 \%$ and $\mathrm{EO} \%+\mathrm{PA} \%=100 \%$.) The PA\% and CA\% communicate how much is correct, while the EC\% and EO\% communicate how much is incorrect. 


\section{Vegetation Cover Error}

As shown in Table VIII, the overall accuracy or correctness of the map representing the amount of vegetation cover is $80 \%$. In both the consumer's and producer's accuracy categories, the map class with the highest level of accuracy is "No Vegetation". In the consumer's accuracy category, the poorest accuracy level was the class of " $50-75 \%$ " with a level of $64 \%$. This level of accuracy is also reflected by a $36 \%$ in the error of commission for the same map class (an estimated $36 \%$ of the " $50-75 \%$ " map class belongs to other map classes - mostly in the " $>75 \% "$ map class).

The poorest producer's accuracy level was the $25-50 \%$ map class with a level of $72 \%$, meaning $72 \%$ of all actual vegetation of this class was mapped. This was reflected in the error of omission, meaning $28 \%$ of the existing amount of this class was missed or omitted.

The map class of " $>75 \%$ " had a consumer's accuracy of $89 \%$ and a producer's accuracy of $76 \%$.

Across the error matrix, $96 \%$ of the map class confusion is between "neighboring" classes. This is important because these classes are "interval" in nature, meaning there is a set order and distance between each class, much like degrees of temperature (Unwin, 1981). Here, if a map class is incorrect, it is very 
TABLE VIII

\section{ERROR MATRIX REPORTING THE ACCURACY STATISTICS FOR THE MAP REPRESENTING THE AMOUNT OF VEGETATION COVER}

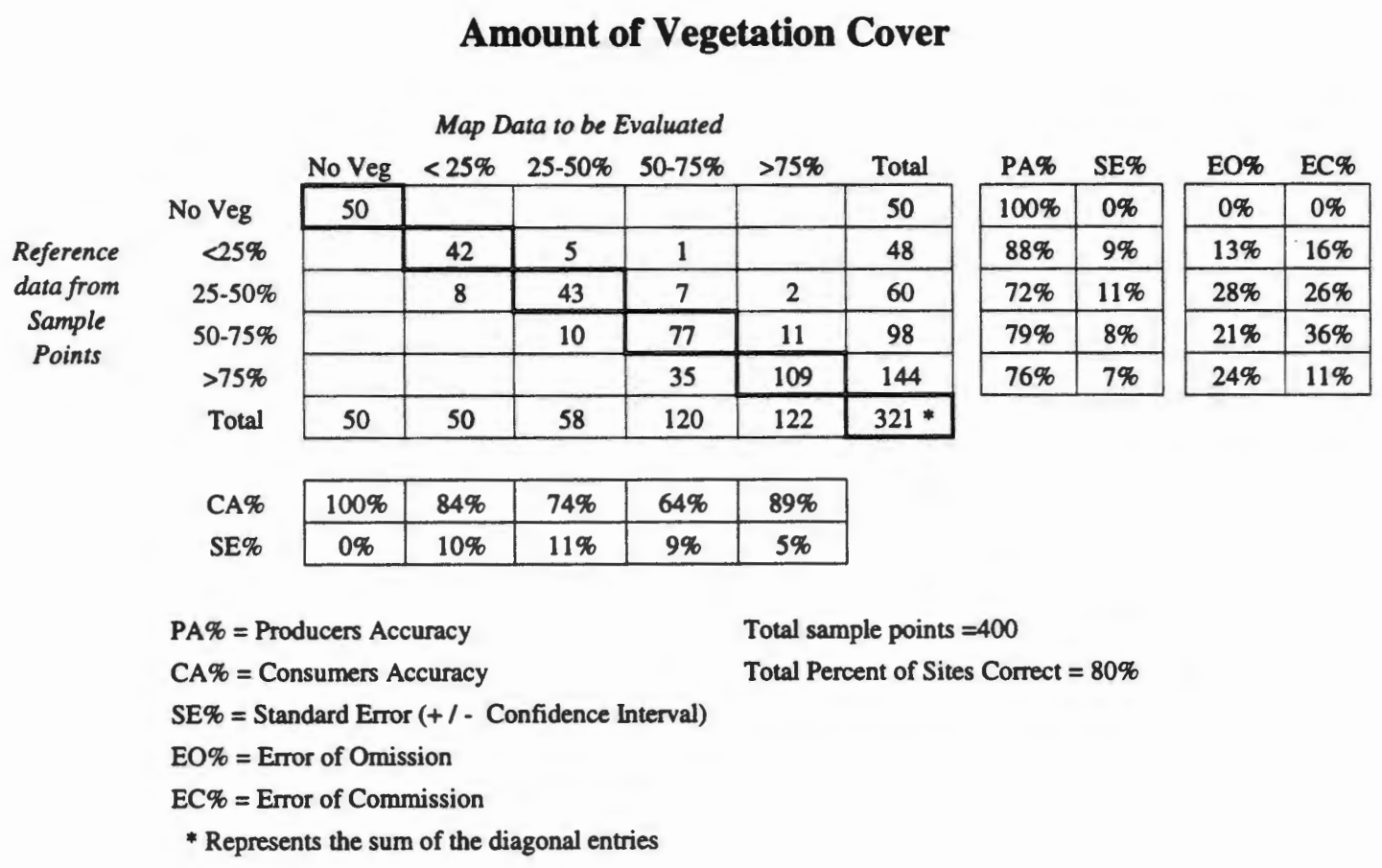

likely to be only one class above or below, rather than two or more classes removed from the target map class.

The confusion between the " $50-75 \%$ " category and the " $>75 \%$ " category was unexpected. Generally in mapping vegetation with satellite imagery, the more vegetation, the higher the accuracy level. Visual inspection of this group of points following accuracy assessment showed that most were located in very fragmented 
landscapes, composed of developed areas with buildings and yards as opposed to areas of unfragmented landscape, such as continuous and largely undisturbed rural forest.

Table IX summarizes each map class's proportion of represented area on the full map of vegetation amount. Although the smallest proportion is " $<25 \%$ " with $8 \%$ of the area, together with the "No Vegetation" class, almost a $1 / 3$ of the mapped area has little or no vegetation.

The " $>75 \%$ " class covers $30 \%$ of the area (almost another $1 / 3$ of the area). Because vegetation "amount" includes all vegetation types, grass fields will contribute to this amount for the " $>75 \%$ " class along with patches for full tree cover.

\section{TABLE IX}

\section{PROPORTION OF MAP AREA COVERED BY EACH MAP CLASS WITHIN THE PROJECT AREA}

\begin{tabular}{|c|c|}
\hline Class & $\begin{array}{c}\text { Proportion of } \\
\text { Study Area }\end{array}$ \\
\hdashline No Veg & $19 \%$ \\
\hdashline $25 \%$ & $8 \%$ \\
\hdashline $25 \%-49 \%$ & $22 \%$ \\
\hdashline $50 \%-75 \%$ & $21 \%$ \\
\hdashline$>75 \%$ & $30 \%$ \\
\hline
\end{tabular}




\section{Vegetation Type Error}

Table X shows that the overall accuracy of the map representing the type of vegetation is $73 \%$. As with the vegetation cover error, the "No Vegetation" map class had the highest level of accuracy (100\%) for both consumer's and producer's accuracy. The lowest levels of consumer's accuracy belong to the map classes of “Grass" (58\%) and "Deciduous" (52\%). Lowest levels for producer's accuracy were the "Grass" class (58\%) and "Deciduous / Grass" map classes (51\%).

The low levels of accuracy for both "Grass" and "Deciduous" were a surprise, especially after the initial visual assessment which found them to be of a much higher accuracy level. However, the visual assessment likely focused on large, easy to identify, nearly homogenous areas of these two cover types. What is reflected here in the quantitative assessment is a random sample and likely includes areas that are much less homogenous than those examined during the visual analysis.

Other classes ranged from $60 \%$ to $84 \%$ for consumer's accuracy and $60 \%$ to $88 \%$ for producer's accuracy.

Unlike the error matrix for the vegetation cover map classes, these map classes are not interval in nature, but rather nominal ( categorical). This means that there is no order or regular "distance" between map classes (Unwin, 1981). 


\section{TABLE X}

\section{ERROR MATRIX REPORTING THE ACCURACY STATISTICS FOR THE MAP REPRESENTING THE TYPE OF VEGETATION}

\begin{tabular}{|c|c|c|c|c|c|c|c|c|c|c|c|c|c|c|}
\hline & & & & & $\begin{array}{r}\text { Typ } \\
\text { Map Dat }\end{array}$ & of of & $\begin{array}{l}\text { eget } \\
\text { aluate }\end{array}$ & ation & & & & & & \\
\hline & & $\begin{array}{l}\text { No } \\
\text { Veg } \\
\end{array}$ & Mix & Grass & $\begin{array}{l}\mathrm{Dec} / \\
\text { Grass }\end{array}$ & $\begin{array}{l}\text { Con I } \\
\text { Grass }\end{array}$ & Dec & $\begin{array}{c}\mathrm{Dec} / \\
\mathrm{Con}\end{array}$ & $\mathrm{Con}$ & Total & PA\% & SE\% & EO\% & EC\% \\
\hline & No Veg & 50 & & & & & & & & 50 & $100 \%$ & $0 \%$ & $0 \%$ & $0 \%$ \\
\hline Reference & Mix & & 42 & 4 & 2 & & & & & 48 & $88 \%$ & $9 \%$ & $13 \%$ & $16 \%$ \\
\hline data from & Grass & & 4 & 29 & 5 & 9 & 2 & & 1 & 50 & $58 \%$ & $14 \%$ & $42 \%$ & $42 \%$ \\
\hline sample & Dec / Crass & & 1 & 12 & 35 & 8 & 9 & & 4 & 69 & $51 \%$ & $12 \%$ & $49 \%$ & $30 \%$ \\
\hline points & Con/Grass & & & & 1 & 30 & 3 & 2 & 1 & 37 & $81 \%$ & $13 \%$ & $19 \%$ & $40 \%$ \\
\hline & Deciduous & & 3 & 5 & 5 & & 26 & 2 & 2 & 43 & $60 \%$ & $15 \%$ & $40 \%$ & $48 \%$ \\
\hline & $\mathrm{Dec} / \mathrm{Con}$ & & & & 2 & 3 & 10 & 41 & 5 & 61 & $67 \%$ & $12 \%$ & $33 \%$ & $18 \%$ \\
\hline & Conifer & & & & & & & 5 & 37 & 42 & $88 \%$ & $10 \%$ & $12 \%$ & $26 \%$ \\
\hline & Total & 50 & 50 & 50 & 50 & 50 & 50 & 50 & 50 & $290^{*}$ & & & & \\
\hline & CA\% & $100 \%$ & $84 \%$ & $58 \%$ & $70 \%$ & $60 \%$ & $52 \%$ & $82 \%$ & $74 \%$ & & & & & \\
\hline & SE \% & $0 \%$ & $10 \%$ & $14 \%$ & $13 \%$ & $14 \%$ & $14 \%$ & $11 \%$ & $12 \%$ & & & & & \\
\hline & Dec $=$ Decidu & & & & & Total Sar & ples $=$ & 400 & & & & & & \\
\hline & $\operatorname{Con}=$ Conife & & & & & Total Pe & cent of & Sites C & arrect: & $=73 \%$ & & & & \\
\hline & PA\% = Prod & ters Acar & racy & & & & & & & & & & & \\
\hline & $C A \%=\mathrm{Cans}$ & mers $\mathrm{ACx}$ & turacy & & & & & & & & & & & \\
\hline & $\mathrm{SE} \%=\mathrm{Stand}$ & rd Error & $+1-C$ & Confiden & ce Interva & & & & & & & & & \\
\hline & $\mathrm{EO} \%=\mathrm{EnTr}$ & & & & & & & & & & & & & \\
\hline & $\mathrm{EC} \%=\mathrm{Enr}$ & f Comm & ission & & & & & & & & & & & \\
\hline & * Represents & & & agana & & & & & & & & & & \\
\hline
\end{tabular}

However, it can be observed that most of the map class confusion is between classes that share similar characteristics. For example, the deciduous class, with its consumers accuracy of $52 \%$ and was often confused with other classes that contained deciduous trees as a part of the mixture. (Twenty percent of the "Deciduous" sample was confused with the "Deciduous/ Conifer" class and $18 \%$ of the sample was confused with the "Deciduous/Grass" class.) In fact, across 
much of the vegetation type error matrix, confusion can be seen between the mixtures, even though the percent correct is dominant. The same type of confusion or overlap between classes can also be seen on the error matrix of vegetation amount.

Finally, a surprise was the accuracy level for the "Conifer / Grass" map class. Even though this category was identified during the unsupervised classification as a unique cluster class, it was not expected to have much success in the final map classification. Due to this expectation, the level of $60 \%$ (CA\%) was a pleasant surprise.

Table XI summarizes each map class's proportion of represented area on the full map of vegetation types. The classes of "Grass," "Deciduous / Grass Mix" and "Deciduous" make up over $2 / 3$ of the study area. From the standpoint of vegetation amount, this does not mean that these vegetation types cover $100 \%$ of the area, but that $2 / 3$ of the study area has varying levels of these components.

The "Mix" class is a mixture of vegetation and hard surface with the hard surface occupying a majority of the area. In this case, there is not likely enough vegetation to get a good "reading" as to its specific vegetation type. 
TABLE XI

\section{PROPORTION OF MAP AREA COVERED BY EACH MAP CLASS WITHIN THE PROJECT AREA}

\begin{tabular}{|c|c|}
\hline Class & $\begin{array}{c}\text { Proportion of } \\
\text { Study Area }\end{array}$ \\
\hdashline No Veg & $19 \%$ \\
\hdashline Mix & $8 \%$ \\
\hdashline Grass & $26 \%$ \\
\hdashline Dec/Grass & $21 \%$ \\
\hdashline Con / Grass & $1 \%$ \\
\hdashline Deciduous & $20 \%$ \\
\hdashline Dec/Con & $3 \%$ \\
\hline Conifer & $3 \%$ \\
\hline
\end{tabular}

\section{DISCUSSION OF ERROR}

Both visual and quantitative methods show that the methods used to construct the two maps of urban vegetation produced reasonable overall results. However, there was significant error found, particularly with certain classes. What are some factors that contributed to error?

\section{Causes of Error}

Map error in the work of producing the two maps of vegetation can likely be traced to four main causes;

1) Incorrectly identifying a vegetation class during photo interpretation

2) Misregistration of photo and image (sampling in the wrong location)

3) Spectral confusion between map classes (land cover not discernible) 
4) Blunder (i.e., entering wrong map codes, etc)

Photo interpretation (PI) is a human process that can yield great results along with potential errors. One source of error in the PI process is the aerial photos themselves. While the CIR aerial photos used for this work were generally of high quality, variation in color tones might mislead photo interpretation for vegetative land cover. This tonal variation results from 3 general influences (Campbell, 1996):

1) Vignetting - a condition where the center of the photo is brighter than the edges of the photo.

2) Angle of illumination - the angle of the sun obviously changes during an aerial photo flight producing variation between photos.

3) Processing of the film - because they are produced individually, aerial photo prints are not necessarily "tone matched" and may show tonal differences between photos.

Tonal variation has the potential to result in photo interpretation errors. To the interpreter, what looks like deciduous land cover on one photo, may appear as conifer on another photo. Some of the tonal variation may be minimized through processing of the film and prints, but the interpreter must still be alert to the potential variation so that it can be minimized. 
Misregistration between the image and the reference data is also a source of error. As mentioned earlier, the extreme heterogeneous nature of urban land cover adds difficulty to finding each point of reference on aerial photos. During the unsupervised classification work, the distance of one cell could be the difference between a match and a mismatch between a PI sample point and the image cell to be classified associated with the land cover data. Using the additional data of streets and raw imagery as guides to the sample point minimized this error.

Spectral confusion between vegetative land cover classes is what the methods of "spectral stratification" and unsupervised classification attempted to minimize. If this is a source of error, there is the potential that generating more spectral clusters could lower the error. There is also the likelihood that no more information can be extracted from the image.

"Blunders" are a potential in any work. The chance of a blunder is minimized by preplanning work strategies and double checking work.

\section{Other Errors}

There were two other specific errors that should be noted. "Mixels," as described in chapter 3 , are pixels or cells that cross land cover boundaries. They are not themselves an error, but will lead to error in the mapping results. They should be readily expected in the heterogeneous urban environment because of the 
image cell size ( 30 meters resampled to 25 meters). They are likely most noticeable in the vegetation cover (amount) classification because they can "divide" areas of what would be a high amount of cover into a smaller category. For example, what is "25\%-50\%" cover could be divided class to the "less than $25 \% "$ cover category (Figure 31 ).
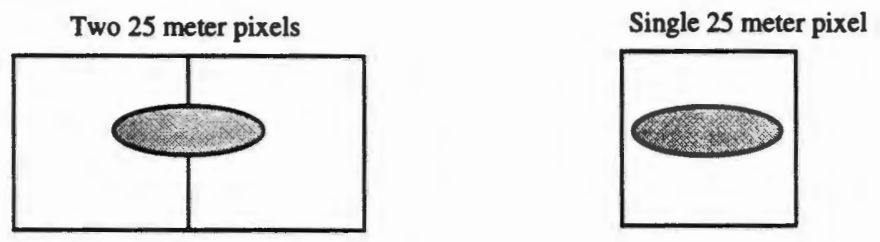

Figure 31. Vegetation as divided be two image cells and covered by a single image cell.

The other observed problem (related to mixels) was that mixtures of water (including wetland) and vegetation (deciduous and also grass) would often be confused with the pure conifer class or mixtures including conifer. There is little that can be done to prevent these two specific error observations . (This was not reported in the error matrix, but was noted during visual assessment.)

\section{Error in the Accuracy Assessment}

Quantitative accuracy assessment (such as done here) provides a valuable measurement of the map products generated from remotely sensed imagery. It 
gives an objective sense for overall accuracy, as well as the accuracy of individual classes. It also provides clues that could direct changes if this work were to be replicated (such as looking to better defined spectral samples of deciduous).

However, it should also be noted that accuracy assessment sampling is just another method of measuring the vegetative land cover and likely contains errors in itself. Many of the same sources of error that influenced the initial map classification work could also influence the accuracy assessment results. An example would be the factor of misregistration. The distance of one cell could be the difference between a match and a mismatch between the sample point and the classified map.

These factors certainly do not invalidate accuracy assessment, but demonstrates that the assumption of reference data being fully without error is likely to be not correct.

What could be done differently to increase accuracy?

By examining the trends on the error matrices, it was concluded that a majority of the error is likely attributed to spectral confusion and to a smaller degree, photo interpretation. As discussed earlier, there was significant "overlap" between certain classes (such as deciduous and deciduous/grass). This infers spectral confusion. 
Future work of this nature may be able to produce generally higher accuracy rates by generating more unsupervised classes for the vegetative land cover types whose accuracy level is less than $70 \%$. However, there is a limit to how much information can be extracted from LANDSAT Thematic Mapper imagery due to its coarse spatial resolution relative to the heterogeneous nature of the urban environment. For some of these map classes, this limit may have been reached.

\section{ACCURACY SUMMARY AND CONCLUSIONS}

Besides being able to communicate a relative level of confidence in the accuracy of maps produced, accuracy assessment is also useful for providing insight as to what could be done better the next time the map is produced. It is also useful to better "frame" the summary statistics of map class areas for what they really mean - that they are only estimates, not absolute numbers.

\section{Comparison to Other Studies}

The lack of assessed accuracy in other efforts that produced maps of urban vegetation prohibits the comparison of this study's assessed accuracy with other similar studies. ( This lack of assessed accuracy in many remote sensing studies is unfortunate because it often misleads people into thinking that the results of the mapping method are $100 \%$ correct.) 
In more traditional uses of LANDSAT Thematic Mapper imagery (e.g., rural forest, agricultural lands, etc.), accuracy levels are reported more frequently and generally vary depending on the desired land cover type detail. Table XII summarizes a selection of studies that reported mapping accuracies (all of which used LANDSAT Thematic Mapper imagery). This summary is not exhaustive, but its range of reported accuracy $(73 \%-93 \%)$ provides a reference for being able to judge reasonableness of map accuracy produced from other satellite imagery based projects.

Based on this reference, the overall accuracy level of the maps produced in this thesis ( $80 \%$ for vegetation cover and $73 \%$ for vegetation type) have been conservatively termed "reasonable". 


\section{TABLE XII}

\section{SUMMARY OF REPORTED ACCURACIES OF MAPS PRODUCED FROM SATELLITE IMAGERY}

\begin{tabular}{|c|c|c|c|}
\hline Location of Study & Mapping Objective & $\begin{array}{l}\text { Reported } \\
\text { Accuracies }\end{array}$ & Author(s) \\
\hline $\begin{array}{l}\text { National Forests of } \\
\text { western Oregon and } \\
\text { western Washington }\end{array}$ & $\begin{array}{l}\text { Forest crown cover, } \\
\text { tree species and tree } \\
\text { size / structure to } \\
\text { determine amount and } \\
\text { location of "old } \\
\text { growth" forests }\end{array}$ & $\begin{array}{l}82 \% \text { (overall } \\
\text { accuracy for } \\
\text { determining "old } \\
\text { growth" forest) }\end{array}$ & $\begin{array}{l}\text { Congalton, Green and } \\
\text { Teply (1993) }\end{array}$ \\
\hline $\begin{array}{l}\text { Lassen Volcanic } \\
\text { National Park, } \\
\text { California }\end{array}$ & $\begin{array}{l}\text { "Genus-level" maps } \\
\text { (e.g., fir, pine, etc.) of } \\
\text { forest lands }\end{array}$ & $73 \%$ & $\begin{array}{l}\text { White, Kroh and } \\
\text { Pinder (1995) }\end{array}$ \\
\hline $\begin{array}{l}\text { New Hampshire } \\
\text { (southeast) }\end{array}$ & $\begin{array}{l}\text { Forest cover types } \\
\text { (major species) }\end{array}$ & $74 \%$ & $\begin{array}{l}\text { Schriever and } \\
\text { Congalton (1995) }\end{array}$ \\
\hline Wisconsin (northern) & $\begin{array}{l}\text { Forest Cover Types } \\
\text { (major species) } \\
\text { Generalized forest } \\
\text { cover types (conifer, } \\
\text { hardwood, mix) }\end{array}$ & $\begin{array}{l}83 \% \\
93 \%\end{array}$ & $\begin{array}{l}\text { Wolter, Mladenoff, } \\
\text { Host and Crow } \\
(1995)\end{array}$ \\
\hline $\begin{array}{l}\text { Olympic National Park, } \\
\text { Washington }\end{array}$ & $\begin{array}{l}\text { Forest crown cover } \\
\text { Forest tree species } \\
\text { Forest tree size / } \\
\text { structure }\end{array}$ & $\begin{array}{l}87 \% \\
90 \% \\
82 \%\end{array}$ & $\begin{array}{l}\text { Pacific Meridian } \\
\text { Resources (1997) }\end{array}$ \\
\hline
\end{tabular}




\section{CHAPTER V}

\section{SUMMARY AND CONCLUSIONS}

This thesis has added to the body of work that supports urban forest management by showing that urban forest information can be extracted from LANDSAT Thematic Mapper imagery to produce maps of vegetation type and amount. In summary, this effort has:

1. Examined and summarized available urban mapping literature.

2. Outlined a methodology that makes use of, but extends those used in earlier studies (particularly in the realm of image stratification).

3. Developed a land cover classification scheme based solely on vegetation.

4. Performed a statistical assessment to measure the level of accuracy of the maps produced (something that was missing from earlier work).

Overall map accuracies were $80 \%$ for amount of vegetation and $73 \%$ for vegetation type. Based on this, the maps were judged to exhibit a reasonable level of accuracy. Though higher accuracy levels would be desired for particular 
classes, the relatively low-cost of the approach might make it an acceptable tradeoff for busy urban forest managers.

These maps have many potential uses, benefits and clear limitations. What follows is a discussion of these.

\section{$\underline{\text { Usefulness }}$}

- Urban Forest Macro Assessment - Urban forest management requires an organized, planned approach to managing a city's vegetation. This is true whether administered by government, utility or private (non-profit) organizations, or whether it be park lands, street right-of-ways, or vegetation in residential yards. As with management of any entity, the first step is often to take inventory of current conditions. The maps produced here can provide an overall view (or "first assessment") of a metropolitan area showing where, what and how much vegetation exists, as well as where it does not exist.

- Urban Forest Multistage Sampling / Inventory - These maps provide a means to stratify cities into major vegetation categories to help organize further surveys of higher detail inventory sampling.

- Recycling - Estimates of yard debris generation, based on the types and amount of vegetation by neighborhood, can aid collection routing and scheduling. 
- Locate Potential Wind Hazard - Residential areas can be rated according to susceptibility of trees being blown down in a storm and blocking roads.

- Estimating Carbon Sequestering Potential - Biomass and carbon sequestering capabilities of the urban forest can be estimated. Recently, there has be a great deal of interest in this area as a way of reducing greenhouse gases (Rowntree and Nowak, 1991).

- General Evaluation of Urban Ecosystem Health - Vegetation as a practical environmental indicator of urban ecosystem health has been discussed by several Portland agencies.

- Public Education - These maps would also be useful to establish or enhance the public's vision of the urban forest. Whether at public meetings or in brochures, these maps capture people's attention, are easy to read and can instill a tangible view of the variation and extent of the urban forest.

- Further Urban Forest Studies - This map data could be used for analysis questions such as helping estimate relationships between neighborhood vegetation cover and seasonal energy use, find optimal population density / vegetation density relationships, property value / vegetation relationships as well as land use / vegetation relationships. 
- Comparative Urban Studies - This method of urban vegetation map production can likely be used in other cities enabling the vegetative comparison of cities.

- Vegetation Change - Variation of vegetation over time can be estimated. The imagery used for this project (LANDSAT Thematic Mapper) has been continuously collected since 1984 . Imagery back to this date can be obtained, classified and compared to the vegetation maps produced from this work (which used a 1991 image), current imagery, or future imagery. Satellite imagery does exist previous to 1984 , but the image resolution (cell size) is much more coarse than TM imagery and a valid comparison would be difficult.

\section{Limitations}

Beyond the accuracy levels obtained in this work, there are other limitations as to what information can be derived from the satellite imagery. Most are a function of the level of detail (spatial resolution) that the original imagery provides. Small vegetation features may be hidden by structures or may only appear as "Mixed Vegetation" as the area is dominated by hard surface and there is not enough vegetation to get a good "reading" of vegetation type. This concept would also apply to small trees (crown diameter $<5$ feet). If surrounded by grass and / or hard surface, it may be difficult to identify the trees. This would make it 
difficult to distinguish between recently planted areas and areas that have not been planted.

It would also be difficult to make a distinction between yard and street trees as well as the direct estimation of the number of individual trees in an area.

\section{Efficiency of Production}

Compared to ground surveys or pure aerial photo interpretation, this form of mapping provides an efficient means of mapping metropolitan area vegetation for the vegetation classes presented here. Assuming satellite imagery and aerial photography is available, it is estimated that two person-months would be required to produce these maps from start to finish. This time advantage stems from two facts. One, only a small portion of the study area needs to be visited by a person or photo interpreted. Second, assuming a GIS layer is desired, the direct output of this process is a digital map ready for a GIS. Other manual methods require additional time to digitize the hardcopy maps produced from their efforts.

Finally, a safety feature of the image classification method is the ability to easily correct systematic error in the mapping process if it is discovered. For example, if a map class was found to be generally in error due to a photo interpretation error, the correction could be accomplished "globally" across the image area. 


\section{Additional Study}

This work is certainly not the ending point for urban forest mapping. Further study should be encouraged in at least two areas; urban forest mapping through continued remote sensing / image processing work, and further exploration of urban forest characteristics through GIS analysis.

As new, finer resolution sources of multispectral satellite imagery become available, the imagery should be examined for its ability to increase the accuracy of mapping urban vegetation. With this imagery, the technique presented in this thesis should be examined for its transferability.

"EarlyBird" multispectral imagery (EarthWatch, Inc.) with a 15 meter cell size, will be available in late 1997. Although this imagery is four times the spatial resolution of LANDSAT Thematic Mapper, the extreme heterogeneity of the urban environment will likely still be a factor during classification of urban land cover types. For example, while testing differing image resolutions to map urban vegetation, Gaydos (1991) found that there is a "break" at 8 meters. Finer resolutions produced accurate mapping results, but as resolutions became more coarse, mapping accuracy declined. This suggests that urban land cover heterogeneity only becomes less of a problem with image resolutions of 8 meters 
or finer. Therefore, the method presented in this thesis will most likely be needed to manage this condition as it did for LANDSAT Thematic Mapper imagery.

With the map product of this thesis being directly available to a GIS, as well as the availability of other GIS layers that represent urban features, there is potential for further estimation of urban forest characteristics. For example, it is possible to estimate available growing space (AGS) for urban forest vegetation, a topic explored by Rowntree (1984). He used aerial photos to estimate not only the amount of urban vegetation, but also the total amount of growing space available for vegetation. From these estimates, he could then say, for example, if an area was found to have $30 \%$ canopy cover and $45 \%$ AGS, the amount of vegetation could be increased by $50 \%$ (to $45 \%$ canopy cover).

This same approach could be applied using a GIS, and thematic layers of roads, land use, population and building "foot prints." This information could be used to construct a "hard surface density index" map which could be compared with maps of vegetation amount and type to determine an association between the maximum amounts of vegetation possible with various levels of "hard surface density." This technique could draw attention to areas that have reached a maximum level of vegetation, as well as areas that appear under-vegetated relative to other areas of the same hard surface density that are supporting more vegetation. 
The maps produced by the methods documented in this thesis offer tangible benefits towards meeting the information needs of urban forest management. However, it is essential that the technique and the maps it produces are used with a clear understanding of their limitations. These maps can provide an overview of urban forest characteristics and a means of identifying regions or areas within the urban matrix that are relatively homogeneous with regard to types and amount of vegetation cover. As such, the maps have great utility for overall evaluation and planning, and as a tool to indicate where and what kinds of action might be needed. However, detailed determination of specific activities will still require site visits and field observation by urban forestry personnel. These maps can be an invaluable asset to the study and management of the urban forest, but decisions about individual trees and site situations must be made on the site. 


\section{REFERENCES}

Anderson, L. M. and H. K. Cordell. 1988. Influence of Trees on Residential Property Values in Athens, Georgia (USA): A Survey Based on Actual Sales Prices. Landscape and Urban Planning 15:153-164.

Bell, C., L. Gaydos and R. Rowntree. 1993. Measuring the Urban Growth and Changing Vegetation Structure of Sacramento, California using LANDSAT Digital Data. GIS '93 Symposium Proceedings, Vancouver, BC. 1193-1200.

Campbell, J. B. 1996. Introduction to Remote Sensing, $2^{\text {nd }}$ ed. New York: The Guilford Press.

Chakravarti, A. and R. Riwari. 1990. A Basic Research Paradigm in Geography. Journal of Geography March-April:53-57.

Congalton, R. G. 1988. A Comparison of Sampling Schemes Used in Generating Error Matrices for Assessing the Accuracy of Maps Generated from Remotely Sensed Data. Photogrammetric Engineering and Remote Sensing 54:593-600.

Congalton, R. G., K. Green and J. Teply. 1993. Mapping Old Growth Forests on National Forest and Park Lands in the Pacific Northwest from Remotely Sensed Data. Photogrammetric Engineering and Remote Sensing 59:529-535.

Cook, E. A. and L. R. Iverson. 1991. Inventory and Change Detection of Urban Land Cover in Illinois Using LANDSAT Thematic Mapper Data. Champaign, IL: Illinois Natural History Survey.

David, W. 1996. Community Tree Planting: Early Survival and Carbon Sequestering Potential. Journal of Arboriculture 22:222-228.

Dorney J. R., G. R. Guntenspergen, J.R. Keough, and F. Stearns. 1984. Composition and Structure of an Urban Woody Plant Community. Urban Ecology 8:69-90.

Duggin, M. J., R. Rowntree, M. Emmons, N. Hubbard, A. W. Odell, H. Sakhavat, and J. Lindsay. 1986. The Use of Multidate Multichannel Radiance Data in Urban Feature Analysis. Remote Sensing of Environment 20:95-105. 
Dwyer, J. F., Schroeder, H. W., and P. H. Gobster. 1994. The Deep Significance of Urban Trees and Forests. In The Ecological City: Preserving and Restoring Urban Biodiversity, ed. R. Platt, R. Rowntree and P. Muick. Amherst: University of Massachusetts Press. 251-267.

Ebdon, D. 1988. Statistics in Geography. Oxford: Basil Blackwell Ltd.

Environmental Systems Research Institute, Inc. (ESRI). 1997. ArcDoc (on line help), ARC/INFO 7.1. Redlands, CA.

ERDAS, Inc. 1991. ERDAS Field Guide, $2^{\text {nd }} \mathrm{ed}$. Atlanta, GA.

Franklin, J. F. and C. T. Dyrness. 1973. Natural Vegetation of Oregon and Washington. Portland, OR: USDA Forest Service, Pacific Northwest Forest and Range Experiment Station.

Gaydos, L. 1991. Scale Dependent Measurement of Vegetation in Urban Areas. Ph.D. Dissertation. Santa Barbara, CA: University of California at Santa Barbara.

Ginevan, M. E. 1979. Testing Land-Use Map Accuracy: Another Look. Photogrammetric Engineering and Remote Sensing 45:1371-1377.

Grey, G. 1996. The Urban Forest: Comprehensive Management. New York: John Wiley \& Sons.

Haack, B., N. Bryant and S. Adams. 1987. An Assessment of LANDSAT MSS and TM Data for Near-Urban Land-Cover Digital Classification. Remote Sensing of Environment 21:201-213.

Harris, L. D. 1984. The Fragmented Forest. Chicago: University of Chicago Press.

Hay, A. M. 1979. Sampling Designs to Test Land-Use Map Accuracy. Photogrammetric Engineering and Remote Sensing 45:529-533.

Hiss, T. 1989. Reflections: Encountering the Countryside I. The New Yorker, 21 August, 40.

Hiss, T. 1989. Reflections: Encountering the Countryside II. The New Yorker, 28 August, 37. 
Hobbs, E. 1988. Species Richness of Urban Forest Patches and Implications for Urban Landscape Diversity. Landscape Ecology. 1:141-152.

Hord, R. and W. Brooner. 1976. Land-Use Map Accuracy Criteria. Photogrammetric Engineering and Remote Sensing 42:671-677.

Jackson, K. 1985. Crabgrass Frontier. Cambridge: Oxford University Press.

Jackson, M. J., P. Carter, T. F. Smith, and W. G. Gardner. 1980. Urban Land Mapping from Remotely Sensed Data. Photogrammetric Engineering and Remote Sensing 46:1041-1050.

Jensen, J. R. 1996. Introduction to Digital Image Processing, $2^{\text {nd }}$ ed. Upper Saddle River, NJ: Prentice Hall.

Kaplan, R. 1984. Impact of Urban Nature: A Theoretical Analysis. Urban Ecology. 8:189-197.

Khorram, S., J. A. Brockhaus, and H. M. Cheshire. 1987. Comparison of LANDSAT MSS and TM Data for Urban Land-Use Classification. IEEE Transactions on Geoscience and Remote Sensing. GE-25 (2).

Kielbaso, J. 1989. City Tree Care Programs: A Status Report. In Shading Our Cities, ed. G. Moll and S. Ebenreck. 35-46. Washington DC: Island Press.

Kuchler, A. W. 1964. Potential Natural Vegetation of the Coterminous United States. American Geographical Society, Special Publication No. 36.

Kuchler, A. W. 1967. Vegetation Mapping. New York: Ronald Press Company.

Laurie, I. C. (ed.) 1979. Nature in Cities: The Natural Environment in the Design and Development of Urban Green Space. New York: John Wiley \& Sons.

Lipkis, A., and K. Lipkis. 1990. The Simple Act of Planting a Tree. Los Angeles: J. P. Tarcher, Inc.

McBride, J. R. and D. Froehlich. 1984. Structure and Condition of Older Stands in Parks and Open Space Areas of San Francisco, CA. Urban Ecology. 8:165-178. 
McPherson, E. G., D. J. Nowak, P. L. Sacamano, S. E. Prichard, E. Makra. 1992. Chicago's Evolving Urban Forest: An Initial Report of the Chicago Urban Forest Climate Project. Chicago: USDA Forest Service, Northeast Forest Experiment Station.

McPherson, E. G., D. J. Nowak, and R. A. Rowntree. 1994. Chicago's Urban Forest Ecosystem: Results of the Chicago Urban Forest Climate Project. Chicago: USDA Forest Service. Northeast Forest Experiment Station.

Miller, R. W. 1997. Urban Forestry: Planning and Managing Urban Green Spaces, $2^{\text {nd }}$ ed. Upper Saddle River, N.J.: Prentice Hall.

Moll, G. 1989. In Search of an Ecological Urban Landscape. In Shading Our Cities, ed. G. Moll and S. Ebenreck. 13-24. Washington DC: Island Press.

Monmonier, M. 1991. How to Lie with Maps. Chicago: University of Chicago Press.

Pacific Meridian Resources. 1997. National Park Service: Vegetation and Landform Database Development Study. Portland, OR.

Pattison, W. D. 1964. The Four Traditions of Geography. The Journal of Geography 63:211-216.

Poracsky, J. and Houck, M. 1994. The Metropolitan Portland Urban Natural Resource Program. In The Ecological City: Preserving and Restoring Urban Biodiversity, ed. R. Platt, R. Rowntree and P. Muick. Amherst: University of Massachusetts Press. 251-267.

Pryde, P. R. 1988. An Inventory and Evaluation of Natural Areas in San Diego County. Yearbook of the Association of Pacific Coast Geographers Vol. 50.

Reichenbach, M. 1992. Urban and Community Forestry in Oregon: An Assessment with Recommendations for Initiating Action. Salem, OR: State Department of Forestry.

Richards, N. A., J. R. Mallette, R. J. Simpson, and E. A. Macie. 1984. Residential Greenspace and Vegetation in a Mature City: Syracuse, N.Y. Urban Ecology. 8:99-125.

Rowntree, R. A. 1984. Forest Canopy Cover and Land Use in Four Eastern United States Cities. Urban Ecology, 8:55-67. 
Rowntree, R. A. 1989. Urban Forestry, Carbon Dioxide and Global Climate Change. Unpublished manuscript presented at Urban Forestry Working Group Technical Session at the Society of American Foresters National Convention. 9 pp.

Rowntree, R. A., and D. J. Nowak. 1991. Quantifying the Role of Urban Forests in Removing Atmospheric Carbon Dioxide. Journal of Arboriculture 17:269-75.

Sadowski, F., J. Sturdevant and R. Rowntree. 1987. Testing the Consistency for Mapping Urban Vegetation with High-Altitude Aerial Photographs and LANDSAT MSS Data. Remote Sensing of the Environment, 21:129-141.

Sanders, R. A. 1984. Some Determinants of Urban Forest Structure. Urban Ecology. 8:13-17.

Sanders, R. A. and R. Rowntree. 1983. Classification of American Metropolitan Areas by Ecoregion and Potential Natural Vegetation. Research Paper NE-516. Syracuse, NY: USDA Forest Service.

Schoeneman, R. S. and Z. Doyle. 1992. Trees in the Community: Managing the Urban Forest. ICMA 25(May):1-13.

Schriever, J. R. and R. G. Congalton. 1995. Evaluating Seasonal Variability as an Aid to Cover-Type Mapping from LANDSAT Thematic Mapper Data in the Northeast. Photogrammetric Engineering and Remote Sensing 61:321-327.

Smardon, R. 1988. Perception and Aesthetics of the Urban Environment: Review of the Role of Vegetation. Landscape and Urban Planning 15:85-106.

Spirn, A. W. 1984. The Granite Garden. New York: Basic Books.

Stevenson, J. 1988. The Green Belt. New Statesman and Society 25 November, 32.

Stewart, J. S. and T. M., Lillesand. 1995. Stratification of LANDSAT TM Data, Based on Regional Landscape Patterns, To Improve Land-Cover Classification Accuracy of Large Study Areas. ASPRS Proceedings 3:826-835.

Story, M. and R. G. Congalton. 1986. Accuracy Assessment: A User's Perspective. Photogrammetric Engineering and Remote Sensing 52:397-399. 
Tateishi, R. and Y. Mukouyama. 1987. Land Cover Classification Using SPOT Data. Geocarto International 2:17-29

Toll, D., 1984. An Evaluation of Simulated Thematic Mapper Data and LANDSAT MSS Data for Discriminating Suburban and Regional Land Use and Land Cover. Photogrammetric Engineering and Remote Sensing 50:1713-1724.

Tomlin, D. 1990. Geographic Information Systems and Cartographic Modeling. Englewood Cliffs, NJ: Prentice Hall.

Tylka, D. 1989. Critters in the City. In Shading Our Cities, ed. G. Moll and S. Ebenreck. 12-18. Washington DC: Island Press.

Unwin, D. 1981. Introductory Spatial Analysis. New York: Methuen.

U.S. Bureau of the Census. 1991a. 1990 Census of Population and Housing, Summary Population and Housing Characteristics, Oregon CPH-139. Washington DC: U.S. Government Printing Office.

U.S. Bureau of the Census. 1991b. 1990 Census of Population and Housing, Summary Population and Housing Characteristics, Washington CPH1-49. Washington DC: U.S. Government Printing Office.

Van Genderen, J. L. and B. F. Lock. 1977. Testing Land-Use Map Accuracy. Photogrammetric Engineering and Remote Sensing 43: 1135-1137.

Wang, S. 1988. An Analysis of Urban Tree Communities Using LANDSAT Thematic Mapper Data. Landscape and Urban Planning 15:11-22.

Ward, C. 1988. Fringe Benefits. New Statesman and Society. 17 June, 26.

Warner, S. B. 1962. Streetcar Suburbs. Cambridge, MA: Harvard University Press.

White, J. D., G. C. Kroh and J. E. Pinder. 1995. Forest Mapping at Lassen Volcanic National Park, California, Using LANDSAT TM Data and a Geographic Information System. Photogrammetric Engineering and Remote Sensing 61:299-305.

Wolter, P. T., D. J. Mladenoff, G. E. Host and T. R. Crow. 1995. Improved Forest Classification in the Northern Lake States Using MultiTemporal LANDSAT Imagery. Photogrammetric Engineering and Remote Sensing 61:1129-1143. 
Zar, J. H. 1974. Biostatistical Analysis. Englewood Cliffs, NJ: PrenticeHall. 
APPENDIX A

MAPS OF EACH OF THE TEN “GENERAL” SPECTRAL CLASSES 


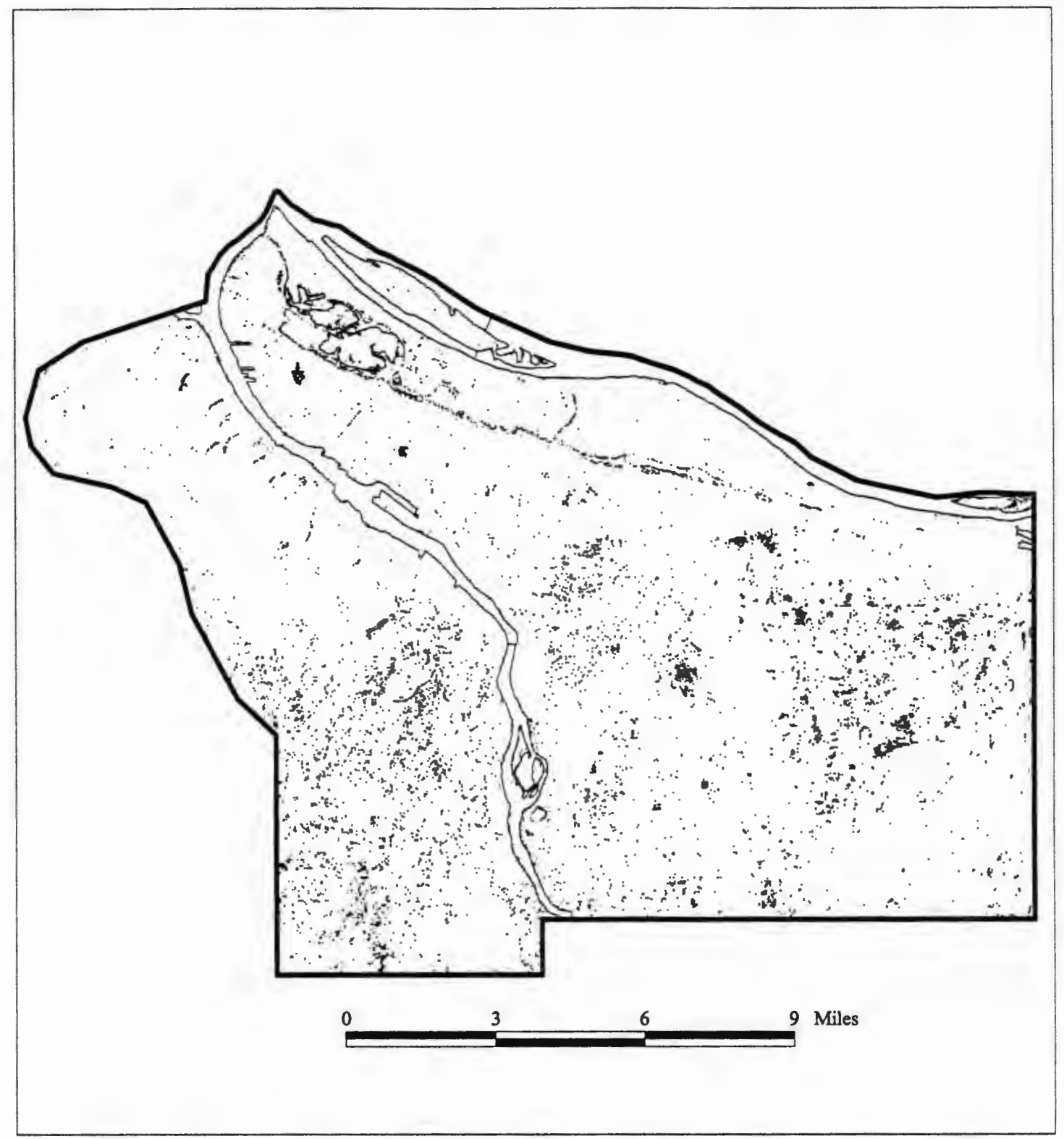

GENERAL SPECTRAL CLASS 1 


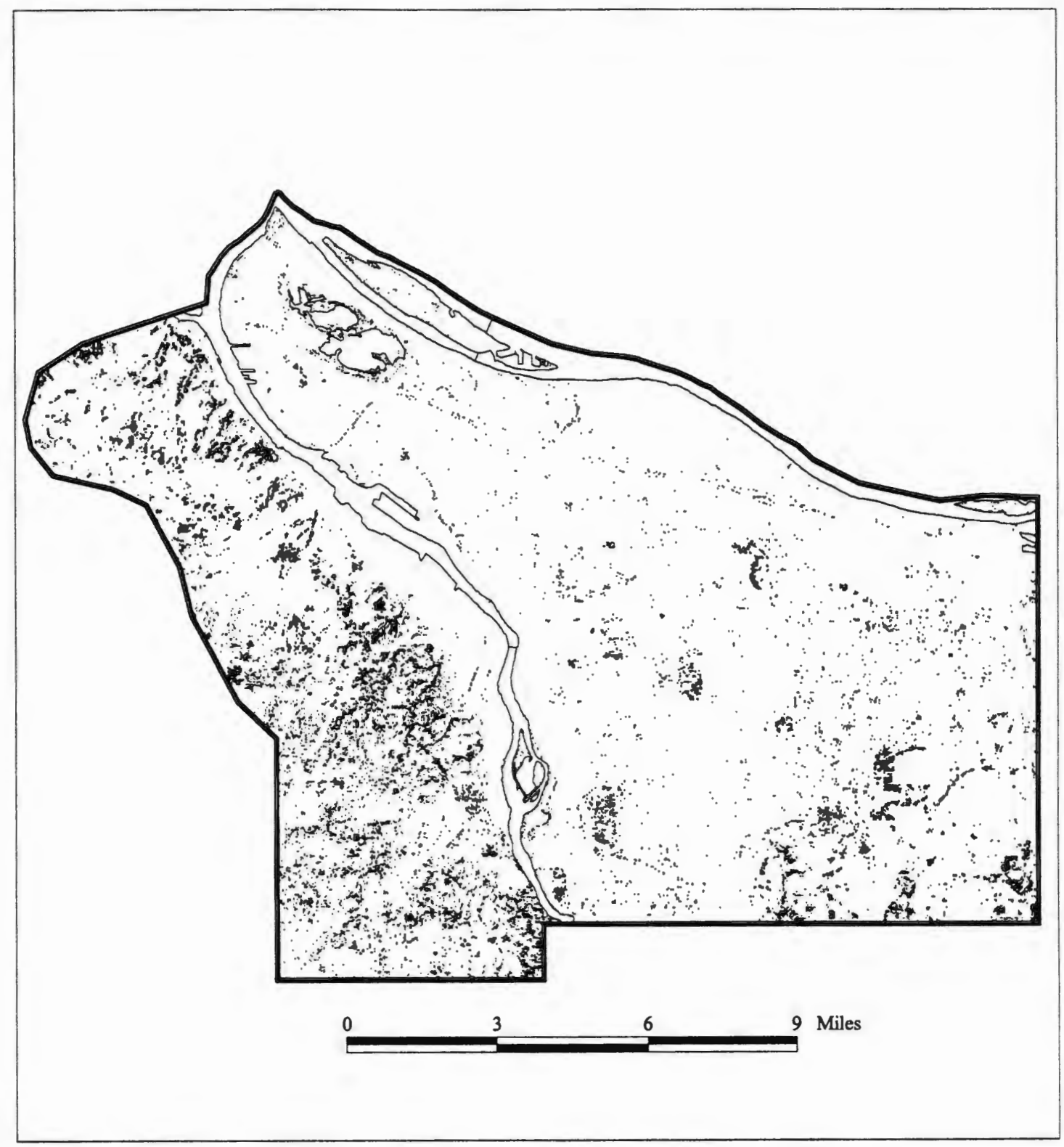

GENERAL SPECTRAL CLASS 2 


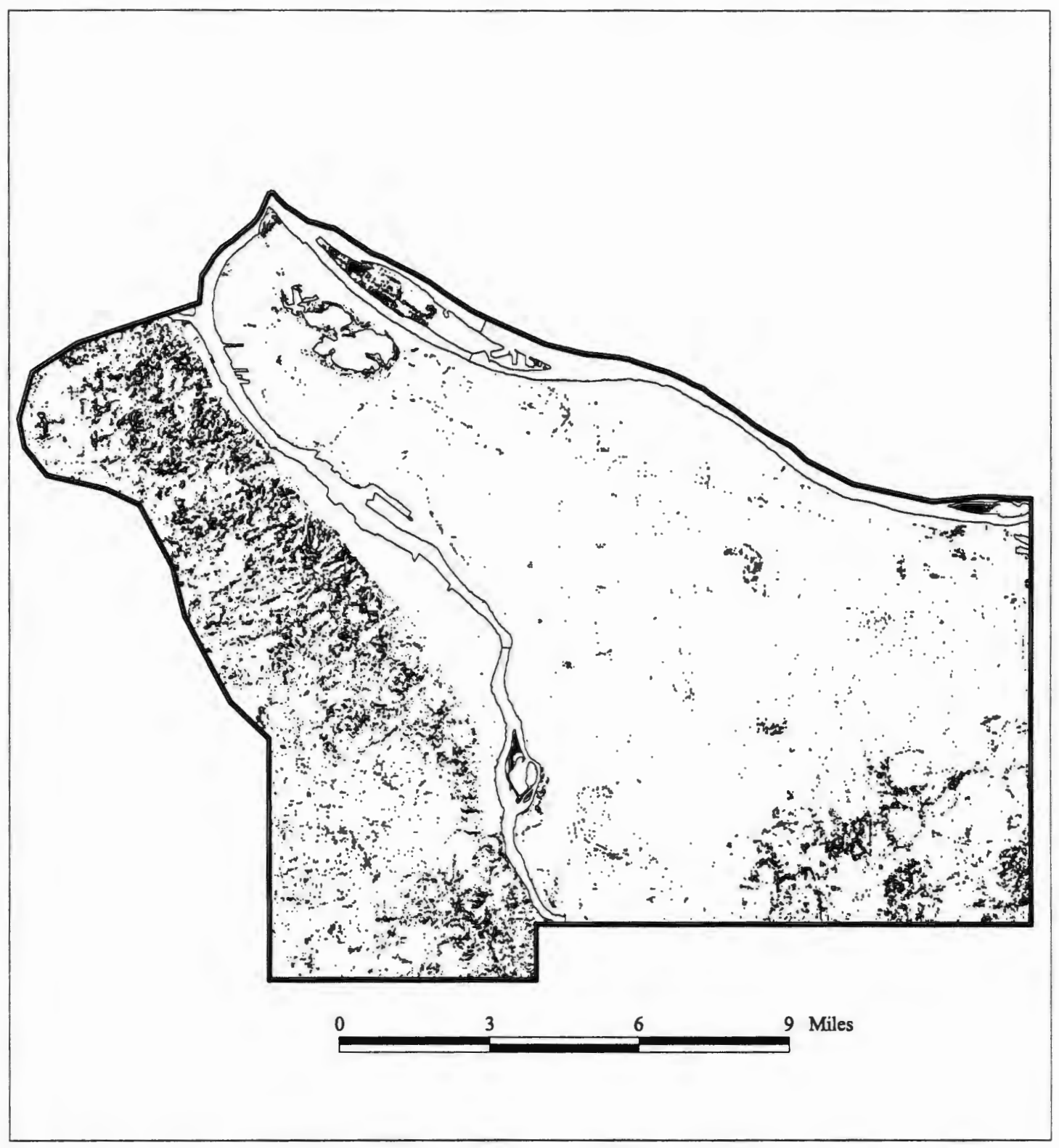

GENERAL SPECTRAL CLASS 3 


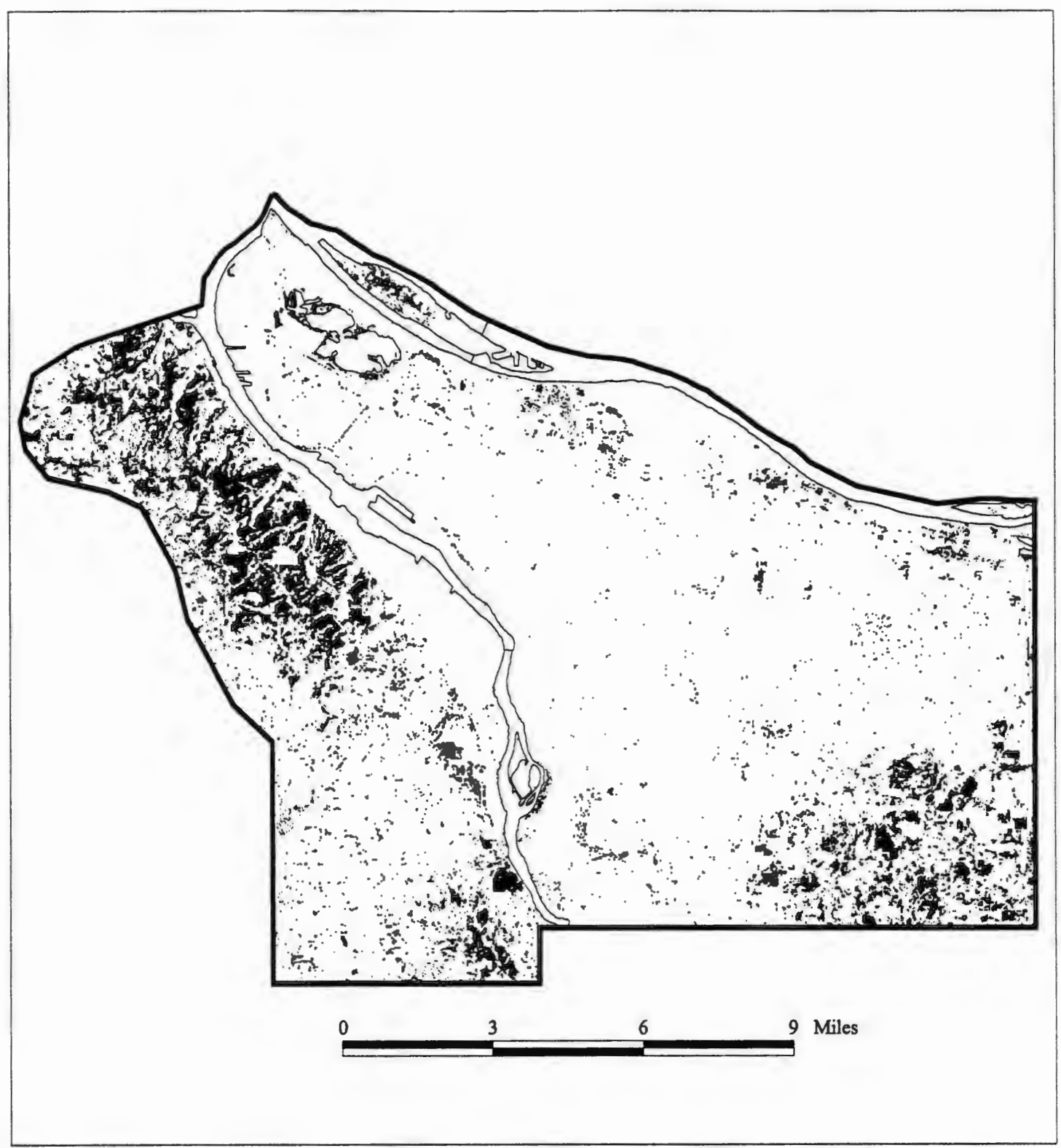

GENERAL SPECTRAL CLASS 4 


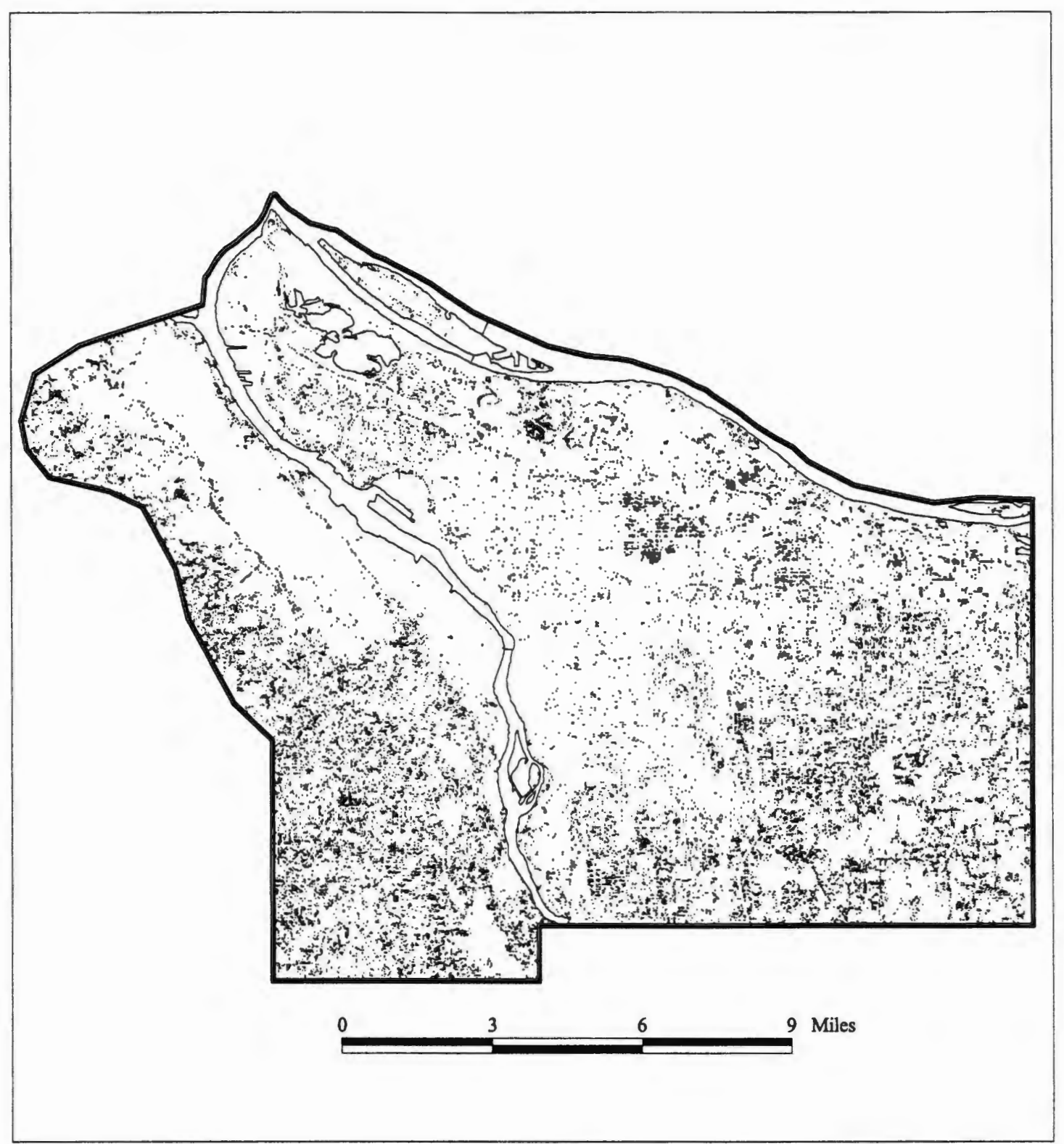

GENERAL SPECTRAL CLASS 5 


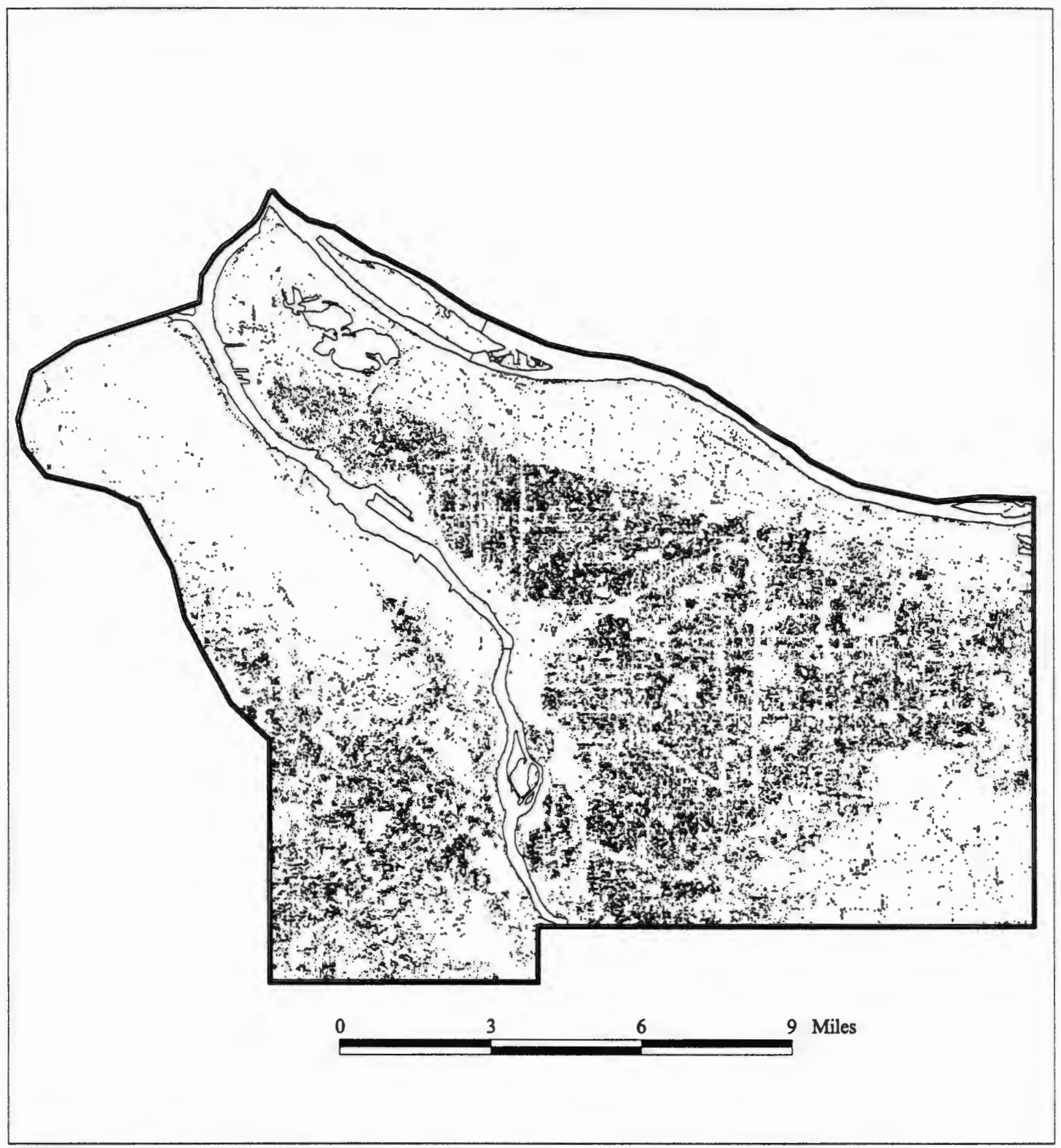

GENERAL SPECTRAL CLASS 6 


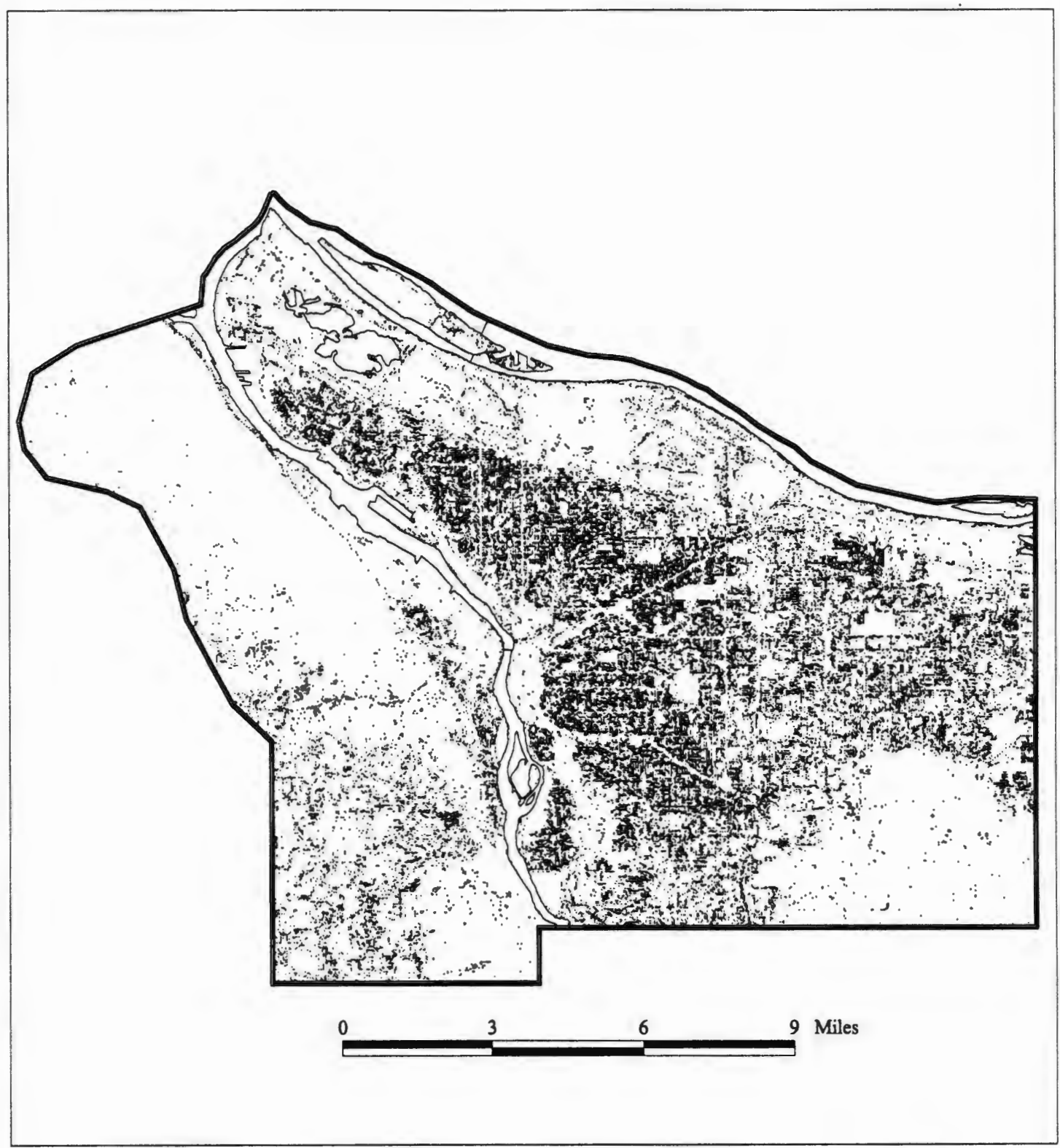

GENERAL SPECTRAL CLASS 7 


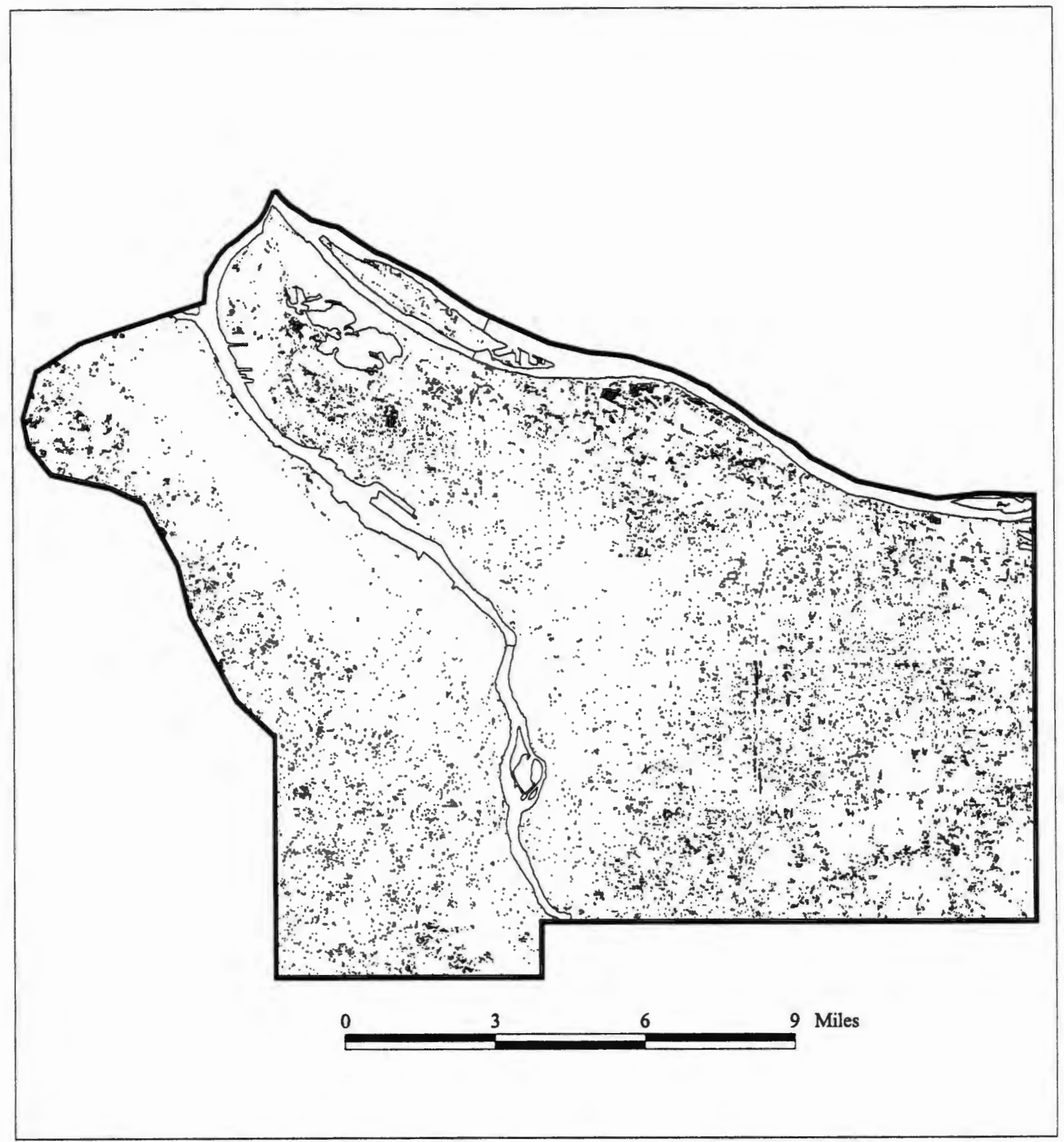

GENERAL SPECTRAL CLASS 8 


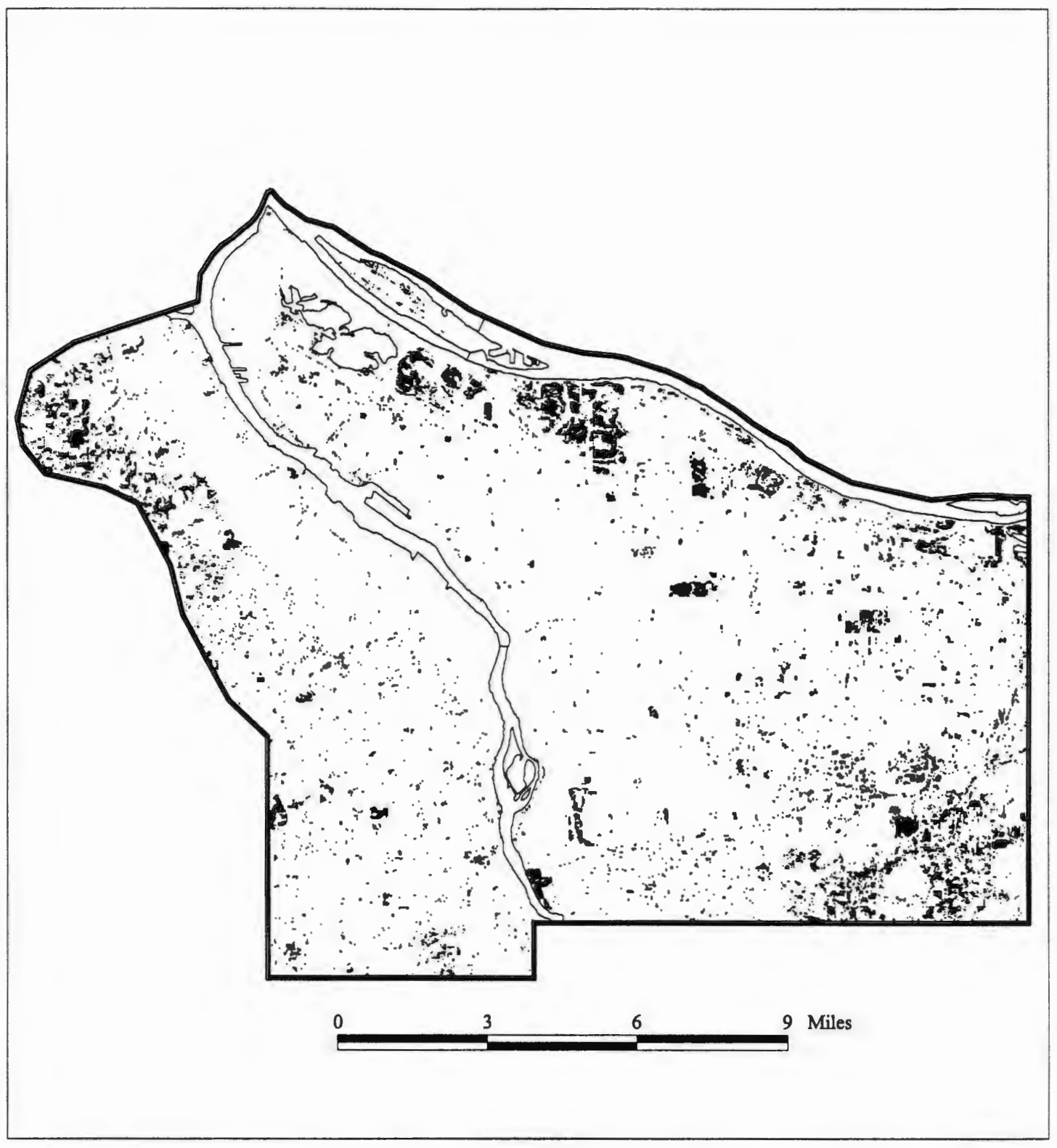

GENERAL SPECTRAL CLASS 9 


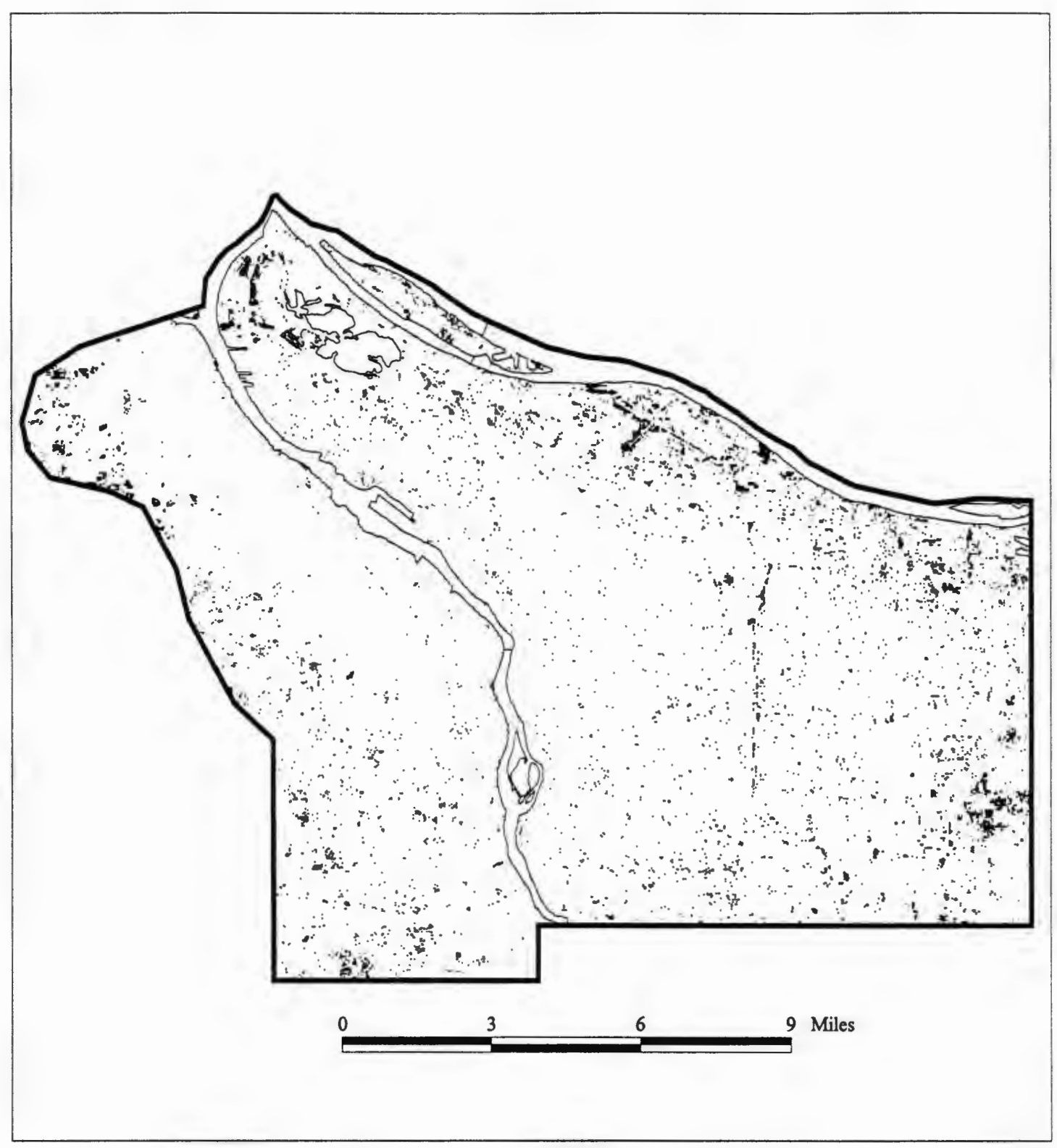

GENERAL SPECTRAL CLASS 10 
APPENDIX B

SUMMARY STATISTICS FOR URBAN VEGETATION IN THE CITY OF PORTLAND, OREGON 


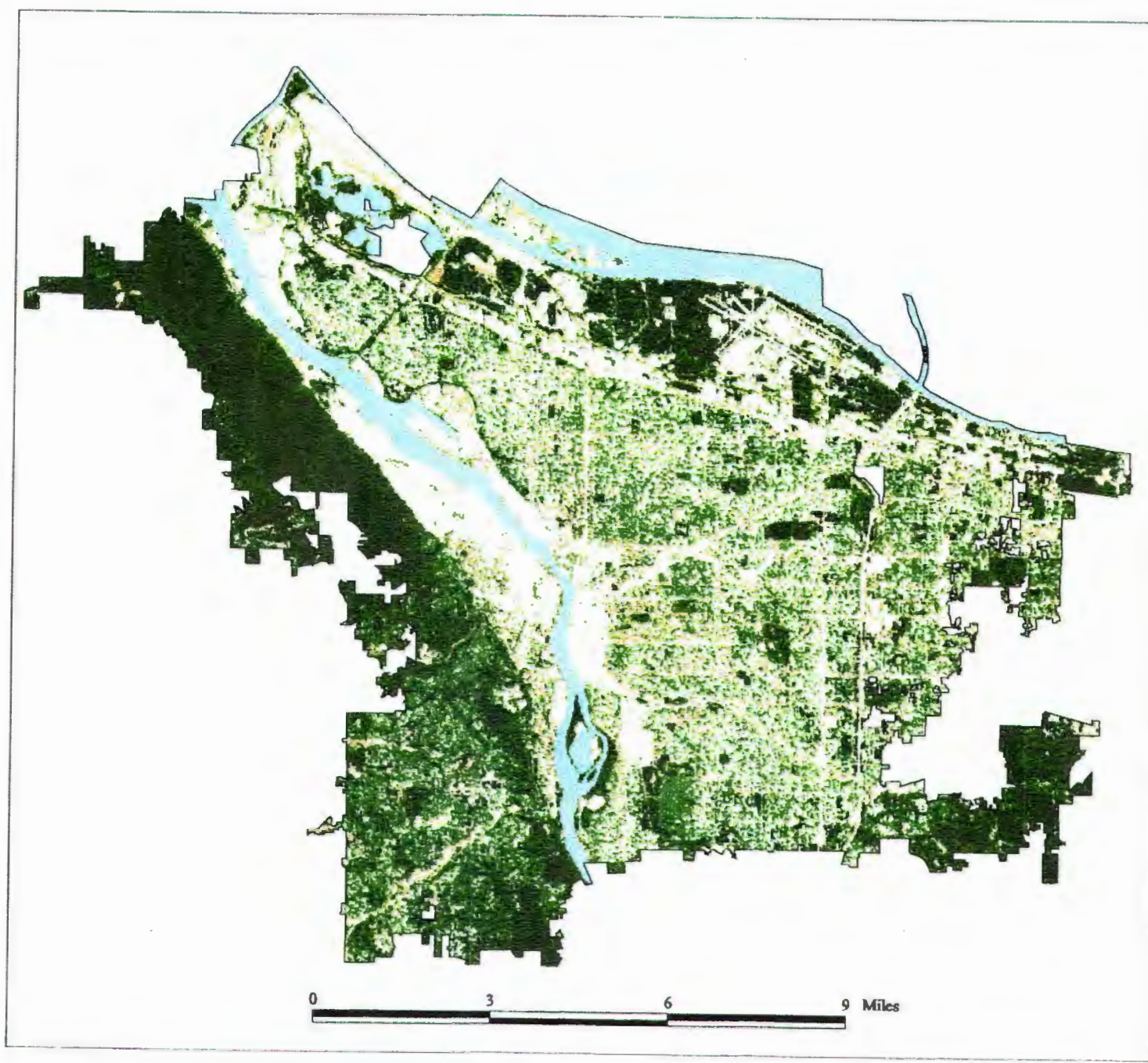

Amount of Vegetation Coverage

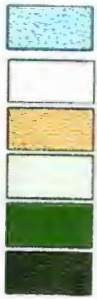

Water

No Vegetation

$<25 \%$ Cover

$25-50 \%$ Cover

$50-75 \%$ Cover

$>75 \%$ Cover
Acres

6,182

13,369

7,787

20,826

17,030

$\underline{21,792}$

Total 86,986
Percent of Area

$7 \%$

$15 \%$

$9 \%$

$24 \%$

$20 \%$

$25 \%$

$100 \%$

Mapped amounts of vegetation coverage with associated acres and percent of area in the City of Portland, Oregon. 


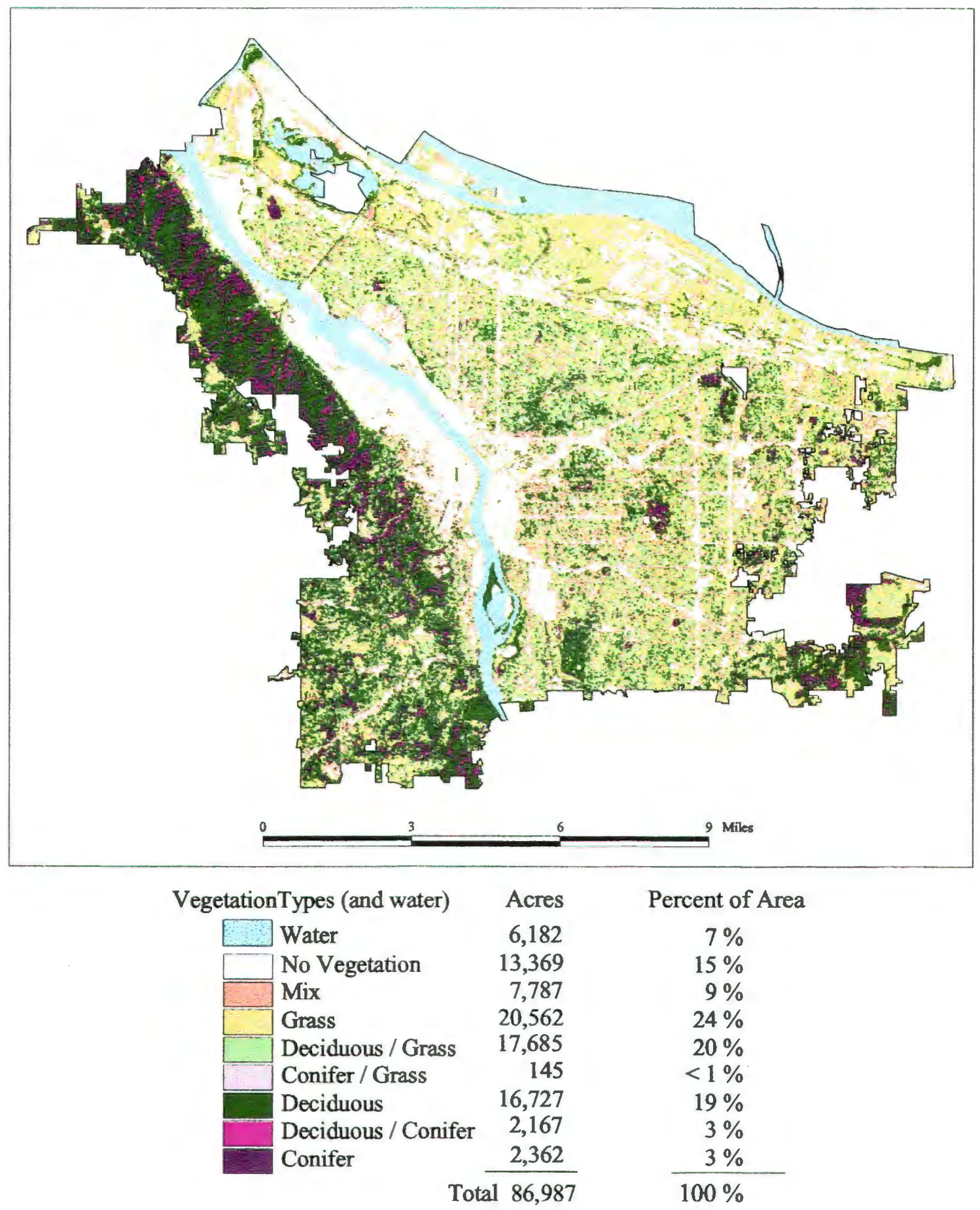

Mapped vegetation types with associated acreage and percent area for the City of Portland, Oregon. The acreage should be interpreted as the amount of land containing a variable amount of vegetation coverage. For example, the grass category may include mixtures of grass and concrete. So, it would not be accurate to conclude that the City of Portland has 20,561 acres of solid grass. Instead, it would be accurate to conclude that Portland has this amount of area with an amount of grass ranging from $1-100 \%$ coverage. 